San Jose State University

SJSU ScholarWorks

Master's Theses

Master's Theses and Graduate Research

Summer 2014

\title{
Native American Response and Resistance to Spanish Conquest in the San Francisco Bay Area 1769-1846
}

Gustavo Adolfo Flores

San Jose State University

Follow this and additional works at: https://scholarworks.sjsu.edu/etd_theses

\section{Recommended Citation}

Flores, Gustavo Adolfo, "Native American Response and Resistance to Spanish Conquest in the San Francisco Bay Area 1769-1846" (2014). Master's Theses. 4462.

DOI: https://doi.org/10.31979/etd.28yu-dtte

https://scholarworks.sjsu.edu/etd_theses/4462

This Thesis is brought to you for free and open access by the Master's Theses and Graduate Research at SJSU ScholarWorks. It has been accepted for inclusion in Master's Theses by an authorized administrator of SJSU ScholarWorks. For more information, please contact scholarworks@sjsu.edu. 


\title{
NATIVE AMERICAN RESPONSE AND RESISTANCE TO SPANISH CONQUEST IN THE SAN FRANCISCO BAY AREA, 1769-1846
}

\author{
A Thesis \\ Presented to \\ The Faculty of the Department of Anthropology \\ San José State University \\ In Partial Fulfillment \\ of the Requirements for the Degree \\ Master of Arts
}

by

Gustavo Adolfo Flores Santis

August 2014 
(C) 2014

Gustavo Adolfo Flores Santis

All Rights Reserved 
The Designated Thesis Committee Approves the Thesis Titled NATIVE AMERICAN RESPONSE AND RESISTANCE TO SPANISH CONQUEST IN THE SAN FRANCISCO BAY AREA, 1769-1846

by

Gustavo Adolfo Flores Santis

APPROVED FOR THE DEPARTMENT OF ANTHROPOLOGY SAN JOSÉ STATE UNIVERSITY

August 2014

Dr. Charlotte Sunseri

Department of Anthropology

Dr. Roberto Gonzalez

Department of Anthropology

MA. Alan Leventhal

Department of Anthropology

Dr. Damian Bacich

Department of World Languages and Literature 


\section{ABSTRACT \\ NATIVE AMERICAN RESPONSE AND RESISTANCE TO SPANISH CONQUEST IN THE SAN FRANCISCO BAY AREA, 1769- 1846}

\section{By Gustavo Adolfo Flores Santis}

This study focuses on how secular, governmental, and ecclesiastical Hispanic Empire institutions influenced the response and resistance of San Francisco Native American groups from 1769 to 1846 . This project draws on late 18th and early 19th century primary Spanish documents and secondary sources to help understand the context of indigenous people's adaptive and response behaviors during this period as well as the nuances of their perspective and experience. Using both electronic and physical documents from a number of archival databases, primary Spanish documents were translated and correlated with baptismal and death mission records. This allowed for formulating alternative perspectives and putting indigenous response and resistance into context. The results of this study indicated that when acts of resistance to the colonial mission system led by charismatic Native American leaders are placed into chronological order, it appears these responses did not consist of isolated incidents. Rather, they appear to be connected through complex networks of communication and organization, and formal Native American armed resistance grew more intensive over time. 


\section{ACKNOWLEDGEMENTS}

I would like to express my deep gratitude to my advisers, Dr. Charlotte Sunseri, Mr. Alan Leventhal, Dr. Damian Bacich, and Dr. Roberto Gonzalez, for their patient guidance, enthusiastic encouragement and useful critiques on my thesis work. Finally, I wish to thank my family, friends, and colleagues for their support and encouragement throughout my study. To Sarah, Pakal, and Ceiba. 


\section{TABLE OF CONTENTS}

LIST OF FIGURES $\quad$ X

CHAPTER 1: INTRODUCTION 1

CHAPTER 2: HISTORICAL BACKGROUND 12

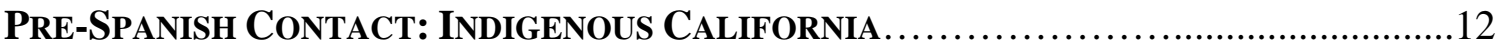

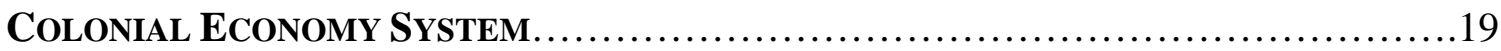

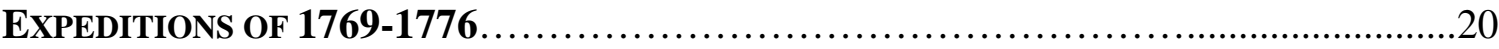

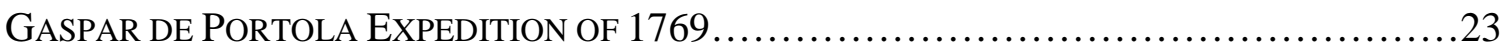

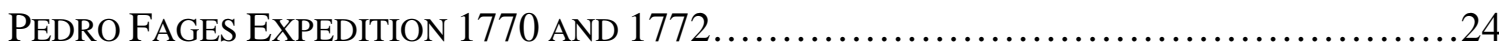

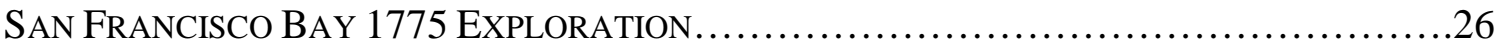

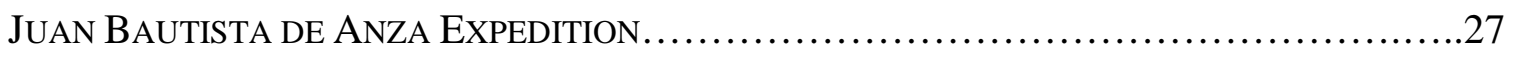

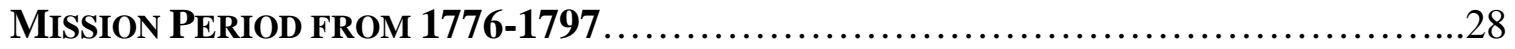

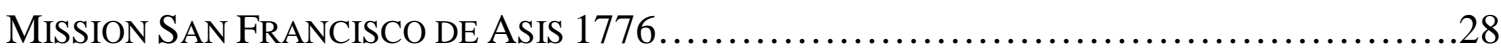

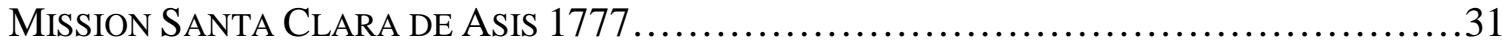

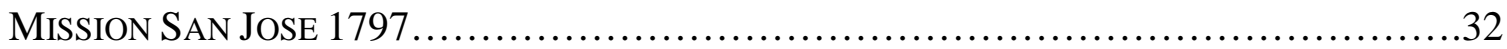

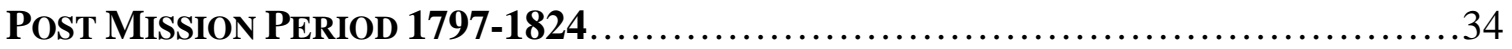

INDIANS AS A TRANSFORMED PEON LABOR FORCE AND THE ECONOMY OF THE

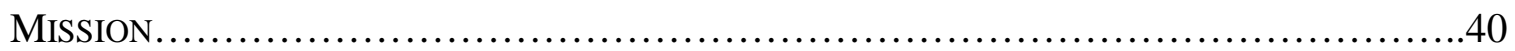




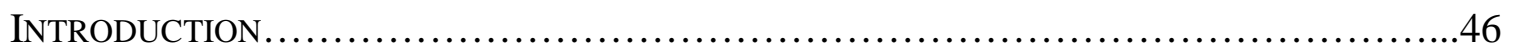

Alternative Perspectives on History: Political AND World System

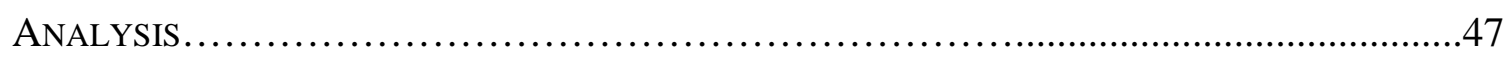

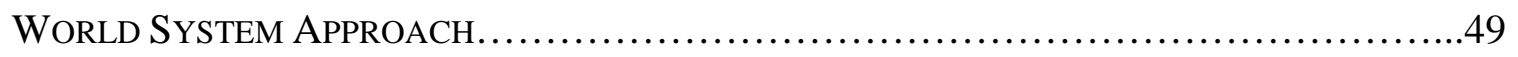

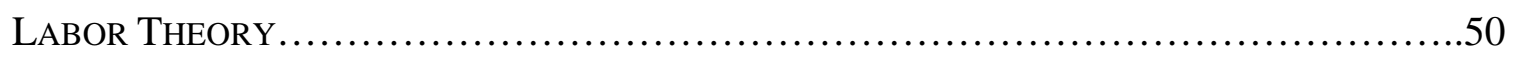

INDIGENOUS ARCHAEOLOGY: A NEW WAY OF DECONSTRUCTING MYTHOLOGY.............53

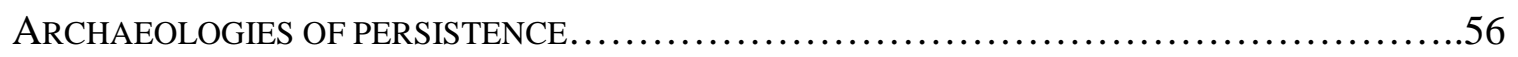

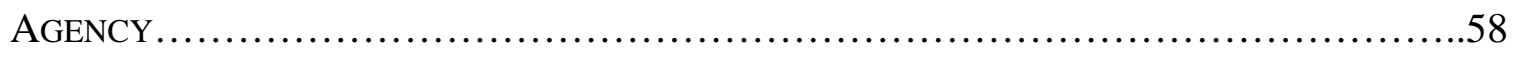

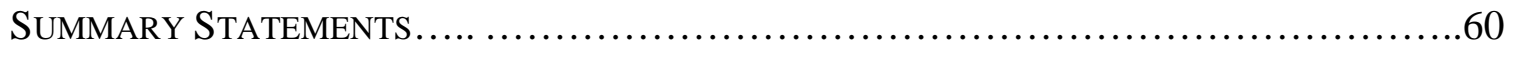

CHAPTER 4: RESEARCH DESIGN

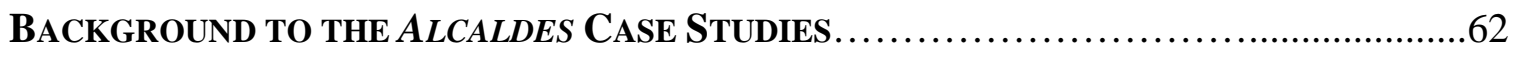

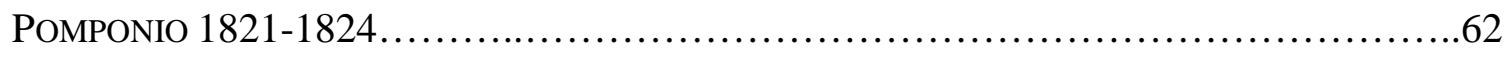

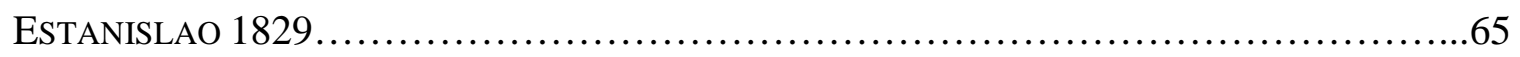

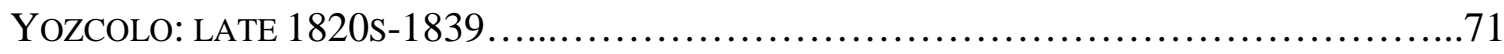

Review and Translation of Primary and Secondary Historical

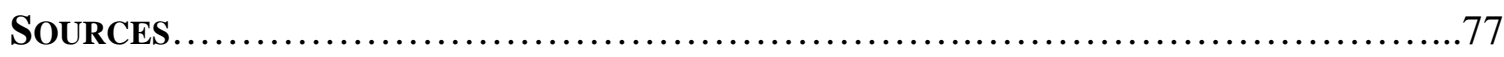

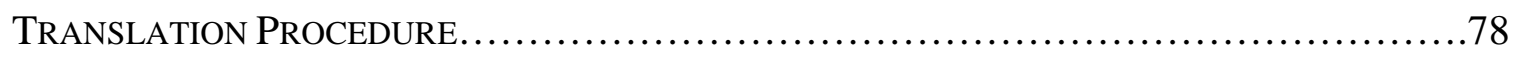




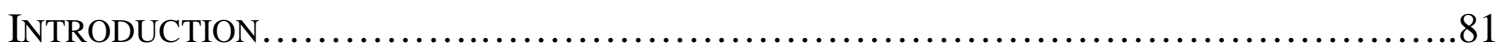

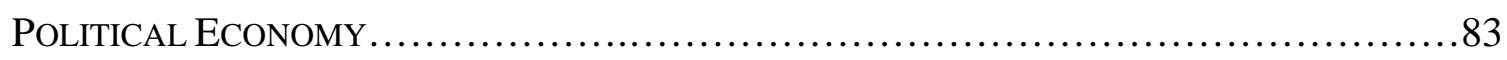

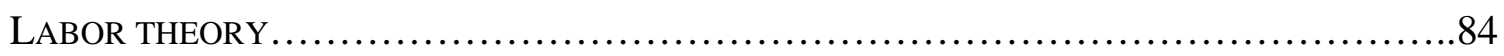

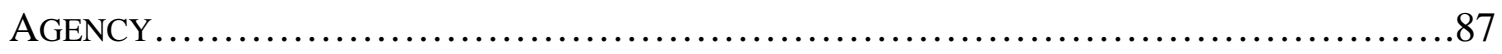

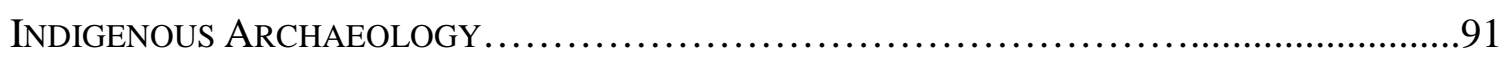

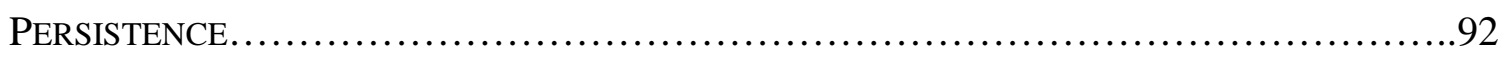

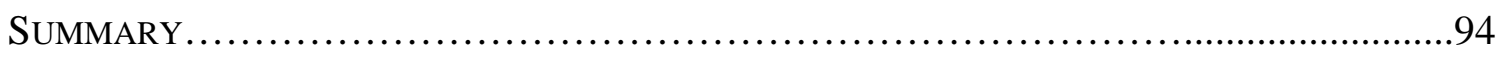

CHAPTER 6: CONCLUSIONS 95

$\begin{array}{lr}\text { REFERENCES CITED } & 105\end{array}$

$\begin{array}{ll}\text { APPENDIX } & 114\end{array}$

1877 Memorias de José Francisco Palomares....................................114

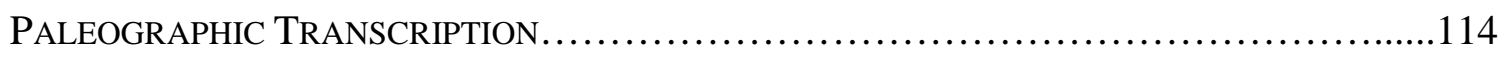

MODERN SPANISH TRANSLATION................................................ 117

ENGLISH TRANSLATION................................................................ 120

1877 JuAn BoJorges ReCUERdos SObre La Historia de

CALIFORNIA.......................................................................................................................122

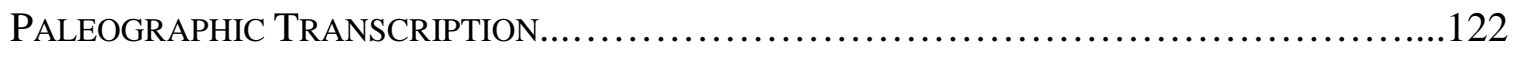

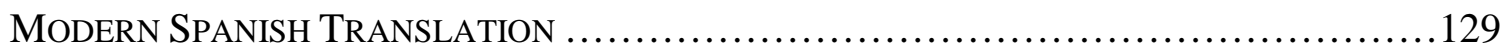


ENGLISH TRANSLATION..................................................... 134 


\section{LiST OF FiguRES}

MaP 1: LANGUage Groups ANd TRIBAL TeRritories of West Central

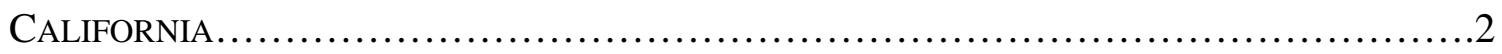

MaP 2: GeOgraphy of the SAn Francisco Bay AREA AND CALIFORnia...............11

MAP 3: Route OF THREE KEy SPANISH InCURSIONS INTO THE SAN FRANCISCO BAy AREA

BETWEEN 1769 AND 1776, AS WELL AS THE LOCATIONS OF SPANISH SETTLEMENTS

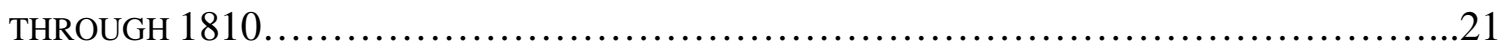

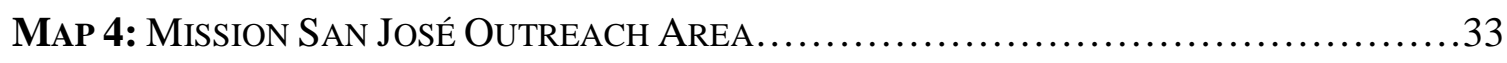




\section{CHAPTER 1: INTRODUCTION}

As a result of the Spanish Empire's entrada (expedition) into Alta California in 1769, Native American tribal groups (Map 1) residing along the coast experienced the onslaught of a multifaceted colonial system. Colonization employed a variety of strategies, including violence, to enforce its rule over indigenous people. This anthropologically oriented study examines the impact of colonial systems and discusses the Native Californian Indians' response, resistance, and persistence in the face of the emergent Spanish Empire. The timeline for this examination includes the late 18th century and early 19th century (Contact Period), missionization from 1770-1836 (Mission Period), and later years through the Bear Flag Rebellion of 1846 (Mexican Period).

The overall goal of this thesis was to situate the response, resistance, and later persistence (survival and adaptive strategies) of the tribal groups who were missionized into the three missions (Dolores, Santa Clara, and San José) located within the greater San Francisco Bay region (Map 2) by employing a historical and anthropological framework. Furthermore, both primary and secondary documentary sources were analyzed in order to investigate the colonial systems that were implemented as a means of establishing superior and subordinate relationships between Spanish authorities (Californios) and San Francisco Bay Area native peoples. Explanations were then presented about the indigenous resistance to those systems. 


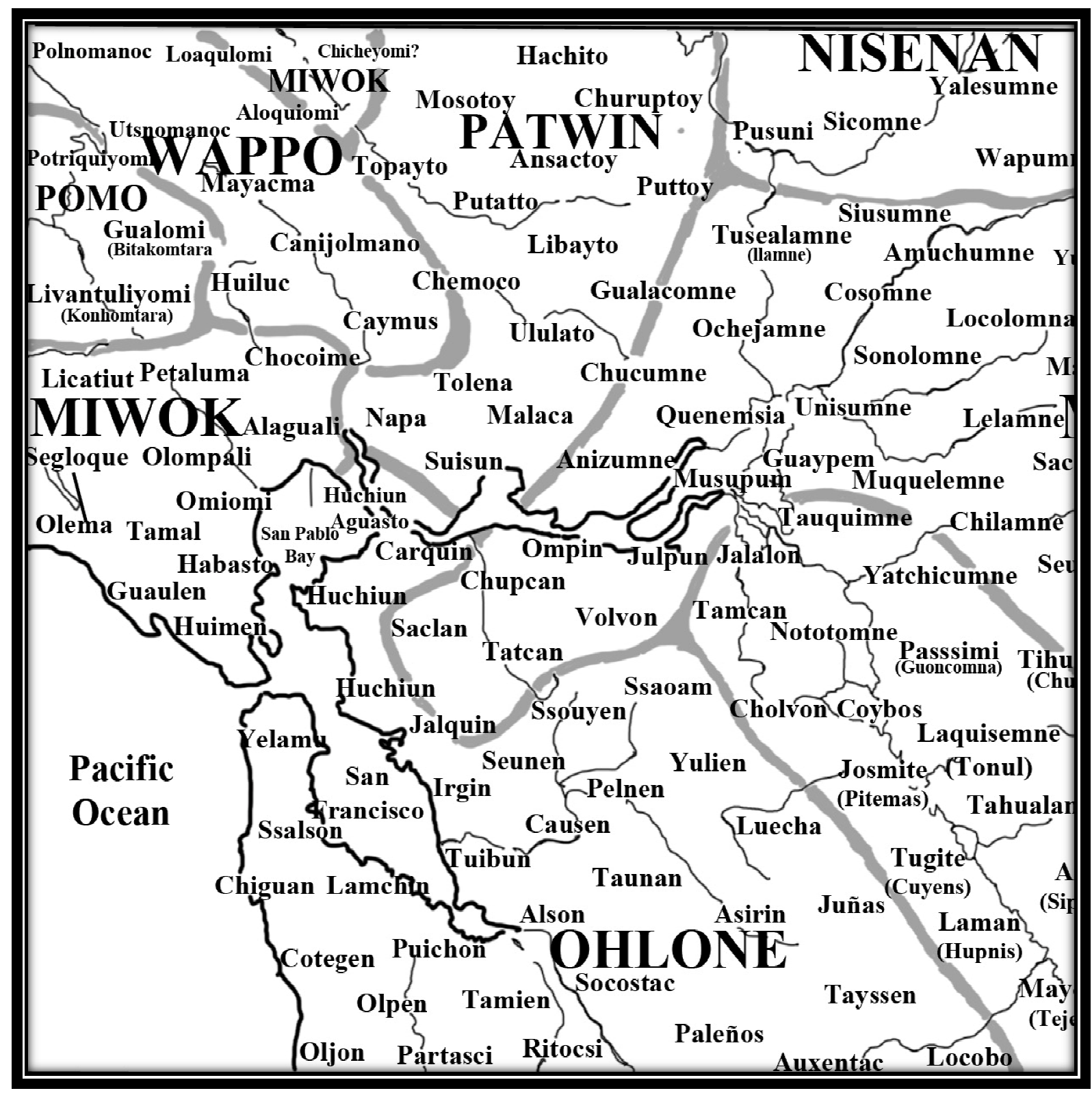

Map 1. Language Groups and Tribal Territories of West Central California (Adapted from Milliken 2008: Map 2). 
Since the arrival of the Spanish colonists, the California Natives' response and resistance included various survival strategies that changed through time. As Lightfoot states, Native people "enacted diverse tactics and social actions to cope with the repressive and structured regime of the Fernandinos [Franciscans]" (2005:88). Survival strategies employed by the indigenous people included 1) maintaining social distances from colonists, 2) overt destruction of relationships with the Spanish elites of the missions, and 3) abandonment of leadership roles of alcaldes within the mission system by becoming resistance leaders (Brown 1976; Gray 1993; Holterman 1970; Lightfoot 2005; Mora-Torres 2005; Sandos 2004). Lightfoot also asserts that "some social actions involved strategies of active resistance, including uprisings, raiding, assassinations, and fugitivism" (2005:88).

During the late 18th century of Alta California's emergent Mission Period, many Native Americans of the San Francisco Bay Area resisted the adverse effects of mission life. The reaction of the Spanish toward this resistance was one of swift retribution and military actions, including the destruction of gentile (non-Christianized) villages harboring runaway neophytes (Cook 1976; Leventhal 1994 et al.; Lightfoot 2005; Milliken 2008; Sandos 2004). This was a successful military strategy due to the mission's spheres of influence within the greater San Francisco Bay Area and adjacent inland areas. Over this time period various levels of response and resistance by missionized native people emerged at several of the San Francisco Bay Area missions. Response can be any reaction to stresses or adaptive strategies brought on by the imposed colonial system, whereas resistance can include "ordinary weapons of relatively powerless groups: foot dragging, dissimulation, desertion, false compliance, pilfering, feigned ignorance, slander, arson, sabotage, and so on" (Scott 1985: 
xvi). In the case of the responses by American Indians during the California Mission Era,

Sandos notes that resistance:

manifested in a nearly infinite variety of ways, practiced by those who accepted the mission and its way of life, but objected to individual tasks or personal abuse. Individual covert resistance prepared the way for overt group opposition. Group resistance, manifested in increasing incidents of physical violence, gradually grew after 1800 (2004:172).

The resistance was led by charismatic missionized Native American individuals whose high status and rank was based on by lineage or their appointment as mission officers (e.g., alcaldes) (Cook 1976; Lightfoot 2005; Milliken 1995; Sandos 2004). Resistance leaders and the Natives people who chose to follow them were considered by the Spanish authorities as criminals, thieves, and murderers and therefore as threats to the established colonial order (Bancroft 1888; Brown 1975; Holterman 1970; Lightfoot 2005; McCarthy 1959).

A review of some of the primary Spanish archives and writings of various historians, anthropologists, and other authors suggests that much of the historical narrative of this period is principally viewed through the lens of the dominant colonial societies. Further, the actions of Native American resistance leaders were indeed declared criminal and therefore the military response was considered justified (Brown 1976; Lightfoot 2005). In order to explore the social and political impact of indigenous people's resistance during this period, this project investigates the documentary evidence of military actions initiated by three California Indian individuals Pomponio, Estanislao, and Yozcolo who emerged as resistance leaders against the Spanish/Mexican colonial systems. This present research focuses specifically on these three alcaldes, or mayors, who served at the three aforementioned San Francisco Bay 
missions and who abdicated their colonial positions of authority and turned against that onerous colonial system.

After reviewing several key published works, I have raised the following questions regarding the treatment of California Indian resistance leaders:

- In what ways were Native American resistance leaders considered criminals versus unsung heroes for their efforts to liberate their people from mission life?

- How do a reexamination and translation of primary Spanish archival documents and historical records provide alternative perspectives about the Native American response and resistance strategies in relation to the arrival and establishment of presidios, missions, and pueblos within their aboriginal homelands?

- How does the history of Alta California mission rebellions relate more broadly to the course of Spanish/Mexican colonial history? What exactly are the social, political, and identity implications resulting from the conquest of Native American tribal communities?

- By employing theoretical methodologies forwarded by Wilcox (2009) in his study of the Pueblo region of the American Southwest, can such research link the history of resistance to the continued persistence of modern-day Native Americans populations/tribal groups of the greater San Francisco Bay Area?

Keeping in mind these previous Native American strategies, the test cases in this study are the individuals who were alcaldes at three missions: Pomponio at Mission San Rafael, Estanislao at Mission San José, and Yozcolo at Mission Santa Clara. Here it is 
argued that economically driven processes led to a situation in which landholders (Spanish authorities and elites) established their power brokerage, employing structural violence and “chronic, historically entrenched political-economic oppression and social inequality" (Burgois 2004:426) against the indigenous peoples. This can be viewed through the establishment of Spanish settlements, missions, and presidios and the ensuing treatment of the missionized San Francisco Native Americans by the colonists in order to gain control of Native American land and people as a labor force, ultimately leading them to resist through the aforementioned strategies.

The development of the culturally adaptive survival strategies and ensuing resistance can be seen as a result of the political and economic divisions between settler elites and the missionized native peoples; these divisions centered on labor, secularization and acquisition of mission-controlled lands, and the rise of Spanish/Mexican and foreign merchants to control California economies. This division served as a mechanism which further disenfranchised the indigenous peoples and in turn provided the fuel to rise up against the colonial system in order to survive and seek alternative strategies. These strategies allowed for their continued persistence, which is defined by Lee Panich as "a continuation of existence in the face of opposition" (2013:107). Historical documents from the years in which this study draws from demonstrate that persistence can be seen in the way that the indigenous people of the Bay Area were able to maintain their identity even under the stress of the colonial system in which they lived. 
Understanding the complexity of the relationships between colonists and Native Americans can be ascertained through the use of ethnohistorical accounts. Many accounts from various Spanish-speaking California elites, or Californios, contain nuances about early California Natives' response to the colonial system. Contained in the historical works compiled by Hubert Howe Bancroft (1874-1890) are accounts that were chronicled during the later Californio historical period.

These historical accounts from secular, military, government, and ecclesiastical personnel from the Spanish and Mexican Periods provide a lens to analyze those processes leading to open conflict, response, resistance, and persistence between native peoples and the Spanish colonial authorities within the San Francisco Bay Area. During this period of time the implementation of forced labor created conflicts as well as forms of differential relationships between the natives and colonists. The use of historical and anthropological approaches allows this study to trace social and political processes in the San Francisco Bay Area microcosm during the Contact, Mission, and Mexican Periods. These accounts help address the research questions concerning the underlying causes of tension, the resistance that arose under mission rule, and the ways in which Spanish colonialism impacted the lives of the indigenous peoples during the period of missionization and conquest.

The study of ethnohistory provides a model that places cultures into a historical context through the examination of first-hand historical documents. These records can help piece together an ethnohistoric account of indigenous people's experiences within colonial San Francisco Bay Area. This is a bottom-up approach to history, which is different from an 
ethnographic or a historical approach to understanding cultures. Ethnohistorical accounts can be useful as they critically view specific institutions of power, such as the colonial power that shaped the physical and social environment of native peoples during the Spanish/Mexican Period of 1769 to 1846 . Many of these written accounts document periods of turmoil that clearly depict tensions and actions that were typical of this time (Bancroft 1888; Beebe and Senkewicz 2006; Brown 1975; Cook 1976; Gray 1993; Holterman 1970; Leventhal et al. 1994; Milliken 1995; McCarthy 1959; Rawls 1986; Salomon 2010; Sandos 2004; Temple 1959; Torres-Mora 2005).

Using primary and secondary sources to reassess early California history can help generate alternative perspectives of the history of Bay Area indigenous groups. As Wilcox states, "historians have emphasized the period of contact as a historical moment in which the pre-Columbian or indigenous past is segregated professionally and theoretically from the advent of Western history" (2005:14). Therefore, putting them into a historical context can help us better understand the indigenous people's response, resistance, and persistence. Wilcox further states that "like many peoples under siege, these (colonial) experiences can animate and strengthen human communities and actually initiate powerful countervailing movements that defy typical notions of Indians' passivity and the supposed 'inevitability' of acculturation" (2009:99). With the hypothesis that the experience of being under siege in the missions strengthened indigenous communities and contributed to tensions that ultimately led to resistance, this project examines those external forces and outcomes of violence during the colonial periods. 
The present study also employs a multi-theoretical and analytical approach to primary and secondary sources by looking at the development of Spanish colonialism in America. Of particular interest is the impact of the Spanish Empire colonialism in California's San Francisco Bay Area and the response, resistance, and ensuing persistence of California Natives to the colonial system through the rise of documented resistance leaders such as Pomponio, Estanislao, and Yozcolo. The applied theoretical methodology approach utilizes a political economy and world systems approach to contextualize the region of California within the broader Spanish colonial world. It also applies Stephen W. Silliman's theory of labor as well as perspectives on agency, in which James C. Scott (1985) states that resistance, "a weapon of the weak," can take many forms. This provides a new lens to view resistance in peasant societies.

Further, the research perspective of Kent G. Lightfoot (2005) is drawn upon concerning indigenous people's patterns of social agency among the Native Californians at Fort Ross. This approach to agency requires the application of a Native American perspective, and the project draws on theoretical approaches of several Native scholars including Michael V. Wilcox (2009) and Rosemary Cambra et al. (1996). Finally, Lee Panich's (2012) approach to archaeologies of persistence that center on identity, practice, and cultural persistence were applied. Before applying these theoretical approaches to the Spanish colonization of Alta California, the following chapter provides a discussion on 1) the historical background on the Spanish entrada into Alta California; 2) the implementation of the colonial mission system and its impacts on the Ohlone, Bay Miwok, Coast Miwok, North Valley Yokut, Patwin and Plains Miwok tribal groups that came under the sphere of 
influence of the Bay Area missions (see Map 1); and 3) the rise of the three Native California Indian resistance leaders as a response to the imposed colonial system.

It is my hope that this study serves as a contribution and stimulus for future research and consideration of alternative perspectives on the history of indigenous resistance within the San Francisco Bay Area (see Map 2) and the surrounding central California tribal regions that will contribute to both the scholarly community and the surviving Native California tribal communities, specifically the Muwekma Ohlone Indian Tribe of the San Francisco Bay Area, whose direct ancestors were missionized into Missions Dolores, Santa Clara, and San José. 


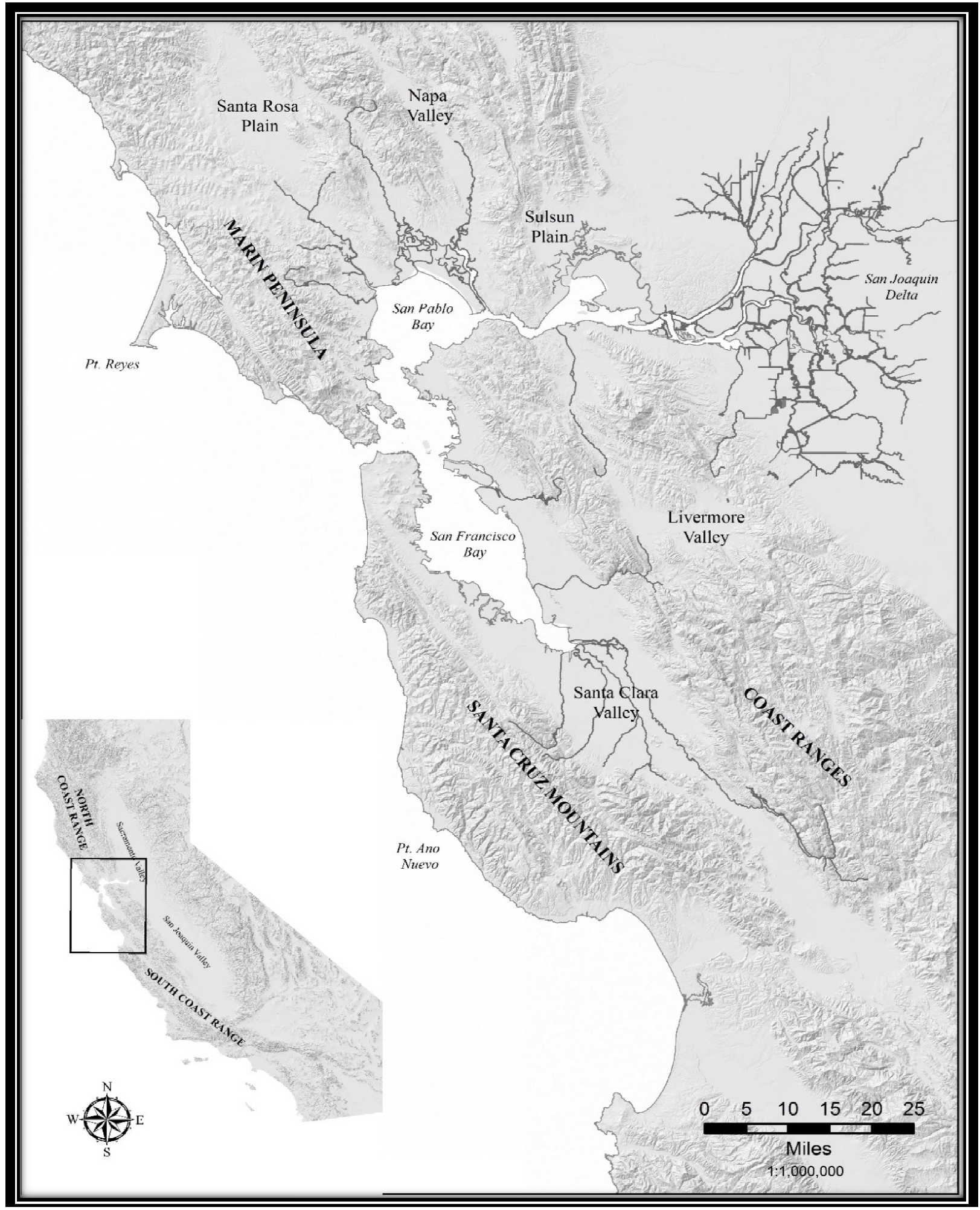

Map 2. Geography of the San Francisco Bay Area and California (Daniel G. Cearly Adapted from Milliken 1995: Map 1). 


\section{CHAPTER 2: HISTORICAL BACKGROUND}

\section{Pre-Spanish Contact: Indigenous California}

Before European contact, the indigenous cultures of California were thriving socially and economically. Scholars who have conducted research in the California region estimate that anywhere from 310,000 to 1,000,000 Indians composed some 70 tribes (Bean and Vane 1990; Dobyns 1966; Sandos 2004). The Indians of California developed complex subsistence and technological systems prior to the arrival of the colonists, through which they "were active participants in the care and nurturance of biological resources, whether in an agricultural sense, planting or harvesting, or through techniques such as irrigation, pruning, and the like" (Bean and Vane 1990:271). Based upon analyses conducted by various scholars, California Indians can be classified as proto-agriculturalists (Bean and Vane 1990). They were land managers through selective burning, and their understanding of the natural environment provided them with resources including collecting, harvesting, and hunting strategies. The California Natives also had in place defined tribal territories where "they occupied, vigorously defended it against trespass" (Boxberger 1990). They also developed an economic system that was supported "by a complex of trade and reciprocity systems" (Bean and Vane 1990:275). Research has provided the lens and an understanding of the complex life ways and cultural systems that evolved among the California Indians prior to the advent of the Hispanic Empire. Bean and Vane (1990) state:

The earlier view that California Indians were rather simple folk has been replaced by a realization that they were complexly organized hunters and gatherers whose social systems were similar to those of peoples with presumably great technological advantages: e.g., horticulturalists and some agriculturalists. Their extensive socio- 
economic network apparently permitted a maximal use of resources across ecological and political boundaries (Bean and Vane 1990:276).

The California Indians developed complex ranked chiefdoms, as evidenced by socially stratified inherited positions of authority that in their cultural world provided a balanced social system,"such as 'wealthy person,' 'commoner,' 'poor person,' and the poor (sometimes slaves and vagabonds, as well) existed in most groups" (Bean and Vane 1990: 279). Other statuses were chief, who acted as an economic administrator, shamans, who were the principal functionaries, and council persons and managers that served with ritual and/or religious systems (Bean and Vane 1990). California Indians also had peacemakers and war chiefs; a skilled warrior would be selected as war chief by the council or the chief (Bean and Vane 1990:281). Various "occupational specializations" (trading, basket-making and clam-shell disk manufacturing) were implemented in the California native social organizational system, which "provided economic advantages for many" (Bean and Vane 1990: 281).

The natural landscape of the San Francisco Bay Area, with its diverse landscape of estuaries, plains, rolling hills, and rugged ridge lands, also contributed to the complex social systems of the natives (Hylkema 2002:235). The indigenous peoples of the San Francisco Bay Area employed various subsistence strategies; these included the harvesting of plant, fish, and animal resources from their local environments. They also enhanced their economy by utilizing their wealth of trade networks established with their neighbors for non-local foods, shellfish, exotic raw lithic materials and other tool making resources (Hylkema 2002). The San Francisco Bay Area Indians developed these trade networks that included items such as "volcanic glass from the upper valley of the Napa River, shells from the coast, sinew - 
backed bows from the east, and tobacco, basketry materials, and ornamental pigments from various locations" (Milliken 1995:17). Scholars have identified the reconstructed trade patterns by, for example, identifying the mineral signature of obsidian in order to trace the complex networking established during pre-contact times. Archaeologists have also excavated mortuary sites that demonstrated evidence of social ranking, wealth, and prestige which supports the interpretation of the evolution of complex societies (Leventhal 1993). These societies were well organized and developed and practiced complex spirituality that brought order to their internal and external social spheres of interaction.

According to several accounts from foreign travelers and expeditions during and after Spanish contact with the San Francisco Bay Area, it is clear that the Native Californians had established their respective territories which were divided among scores of independent tribes (Milliken 1995; Skowronek 2006; Stranger and Brown 1969). These tribes were led by powerful families that were supported by subordinate sub-chiefs (Fages 1775). Small independent tribes inhabited territories covering the San Francisco Bay Area and the neighboring Coast Range. These tribes were in control of territories varying in size from eight to 12 miles wide and consisting of a number of intermarried families organized as an autonomous polity of approximately 200 people (Milliken 1995:21). Kroeber states that the groups consisting of "the smaller settlements were likely to be inhabited seasonally, or by certain families only perhaps for a stretch of years, after which their population might drift back to the main settlement" (1962:33). Despite this information, there are large gaps in our knowledge of the Bay Area native communities at the time of contact. This is due to the rapid adverse impacts caused by missionization. However, this is partially offset by the existence 
of ethnohistoric observations from the earliest Spanish explorers and missionaries as well as incomplete and biased documentation of native life ways by those same forces that sought to control the native populations (Jones and Ferneau 2002:207).

Some of the first-hand Spanish descriptions of Native Californians in journals were written by Spanish military men and Catholic priests on the northbound expeditions into Alta California. These expeditions included territories north of San Diego, including Santa Barbara, Monterey, and the San Francisco Bay (Brown and Stranger 1969; Galvin 1971; Rawls 1992). The Portuguese explorer Juan Rodriguez Cabrillo, while exploring on the behalf of Spain, wrote about encounters with the leather-clad coastal Chumash in 1542 (Rawls 1986:25). Records by the chaplain traveling with Francis Drake to the San Francisco Bay in 1579 noted that the Coast Miwok people were often naked (Rawls 1986:25). Earlier expeditions by Sebastian Rodriquez Cermeño and Sebastian Vizcaino (1595, 1596, 1595, 1602) produced accounts as well, yet the overall written record of these first European explorers remained superficial and did not provide an in-depth analysis of the native groups of Alta California.

The first land Spanish expedition to Alta California was undertaken by Gaspar de Portola in 1769, followed by Fages' parties in the years of 1770 and 1772 (Brown and Stranger 1969). The third expedition was in 1774 by Rivera and Moncada, which focused on recording information about land, resources, and the indigenous people (Milliken 1995). The last major expedition was led by Juan Bautista De Anza in 1776 and focused on bringing permanent settlers for a military base and a mission (Shoup and Milliken 1999: 20). Each of these entradas (first expeditions) had colonial settlers, with a combination of ecclesiastical 
authorities, merchants, engineers, and Indians called indios auxiliaries (Bolton 1933; Brown and Stranger 1969; Milliken 1995; Shoup and Milliken 1999). These early accounts help us to understand the processes and stresses that disrupted the socio-political economic sphere of the Native Americans of the Bay Area.

Each expedition to the Alta California has been documented, and many of the first manuscripts written in what today is called Spanish paleographic writing have provided valuable data about that period of contact, and information about those early colonial settlements of California (Beebe and Senkewicz 1996, 2006; Galvin 1971; Leon-Padilla 1970; McCarthy 1958; Milliken 1995, 2008; Salomon 2010; Skowronek 2005; Temple 1955). Many scholars have depended on these early manuscripts to piece together a history of Alta California, however the focus is unidirectional, with emphasis on the colonial system rather than addressing the perspectives relating to the indigenous people. This unidirectional view does not represent the cultural complexity that was thriving at that time among the California tribal groups.

The Spanish Empire's primary goal-at least for the missionaries-was to convert the Indians to the Spanish Catholic devotion (Rawls 1986). Other explanations for Spanish presence in Alta California include the occupying of lands to benefit the Spanish crown and to fuel the economy through indigenous labor (Blind 2004). Wolf (1959) claims that some of the powerful institutions which possessed capital to embark on journeys were religiously inclined, and had sponsorship of faith in the deeds of the Catholic Church.

The Franciscan priests of the missions did not go in-depth in their writing on the culture of the natives, with the exception of "the linguistic studies of Fray Felipe Arroyo de 
la Cuesta and Fray Buenaventura Sitjar, the replies of eighteen California Missionaries to an official Spanish inquiry in 1812, and Fray Geronimo Boscana’s account of Juañeno religion” (Rawls 1986:26). However they did keep detailed annual reports and accounts of selling of products such as hides, tallow, wheat, corn, heads of cattle and other crops contained in documents, called Informes (Skowronek 2006:162). Other official documents detail accounts on the cultivation, mortality, baptism, natural events, and the emergence of the church in these far-off lands of the Spanish Empire (Skowronek 2006:167).

Rawls states that many of the foreign and European visitors to Alta California in the 19th century characterized the complexion, physiognomy, and stature of the Native Americans as evidence of their extreme "brutishness" and "stupidity" (Rawls 1986:29). However, earlier expeditions to Alta California failed to understand or take careful note of who lived in those lands; instead these chroniclers created narratives and myths that later foreigners began to believe. These were used to portray the Alta California Native Americans in a negative way.

Northern European authorities claimed that the church did not pay attention to the bad treatment of the indigenous people in the "New World" (Rawls 1986:345). The mission treatment of Native Americans was under a wave of criticism that began in the 16th century in regards to Spanish colonial practices in New Spain and others parts of the Spanish Empire. According to Rawls (1986) this view of the church produced many literary accusations mainly in the following two and an half centuries attacking the Spanish colonial system. These cited a treatise written by Bartolome De Las Casas, a priest who was against the mistreatment of the indigenous people (Rawls 1986:42). He wrote extensively against the 
atrocities of the Spanish colonial systems, demanding new native laws and advocating for a more humane treatment of colonized Native people. This rhetoric was used to justify other colonial expeditions to embark in their own conquest of these native lands in order to right the wrongs of the Spanish (Rawls 1986:43).

Despite the views on the treatment of the indigenous peoples Bartolome De Las Casas, there were those who saw the Spanish/Mission colonial system not as a negative enterprise, but rather as a successful initiative that worked in transforming the Native Americans from "savages" into Christian citizens. Rawls discusses early foreigners visiting the missions who thought that the missionaries had transformed the Native Americans by replacing their heathen ways, praising what they viewed as the Franciscans' accomplishments and viewing their actions as humane, just, and enlightened (1986:43). Other visitors were pleased after listening to natives play music at Mission San José. For example, Lieutenant Edmond Le Netrel was impressed by how Indians played instruments and read music (Rawls 1986:41). Rawls states that Captain Joséph de Rosamel, a visiting Frenchman, was impressed with the "'beautiful missions' as fitting monuments to the men who "had civilized this vast and wild country"” (Rawls 1986:41). Spanish/Mexican settlements (Presidios, Missions, and Pueblos) soon began to appear on the land that was inhabited by indigenous groups from San Diego Bay to the San Francisco Bay. As Rawls states, the "missions had their defenders and, after secularization, a long line of eulogizers" (Rawls 1986:39). 


\section{Colonial Economic System}

Spanish settlements became centers to barter Spanish crafts. These centers were comprised of associations of specialists who were ascribed a high social rank and the right to produce a particular craft (Wolf 1959). The introduction of several new animals to California led to new goods. For example, the rasa, or sheep, produced wool and meat. Colonial breeding of horses introduced the mesteños, now known as the mustang (Wolf 1959:182). Another introduction was the implementation of the wheel with animals such as oxen, mules, and donkeys. Using these new tools and animals, mining enriched many stakeholders while others created wealth by sowing and selling agricultural crops (Wolf 1959).

The Spanish relied heavily on the indigenous population for agricultural labor and raising all the products for their economic system (Wolf 1959). The Spanish used indigenous labor, which was the cheapest method and did not require much wealth and machinery, for profit. The Españoles (Spaniards) were invested in raising livestock for their hides and tallow; sheep were valued for their wool. Leather for containers and for military usage in Europe and in New Spain was in high demand. The cash crops required a fertile landscape, therefore the Native American people were displaced as the division of land began. Wolf (1982) explains that indigenous peoples had different methods of using the land. The expansion of the Spanish Empire transformed the indigenous people into to a labor force for the new land owning elites. 


\section{Expeditions of 1769-1776}

The expeditions (see Map 3) to Alta California were conducted by secular, governmental and ecclesiastical institutions sponsored by Don José de Galvez (Viceroy) of New Spain. The main objective was to populate the northern frontiers before Russian and English colonial powers took the land of California. Galvez "developed a colonization plan for Alta California" (Shoup and Milliken 1999:17). These initial plans were not that popular among colonists, but the Franciscan order seemed to be on board to implement the plan that Galvez had introduced. However, in the written records of these explorers/colonist/missionaries, we can comprehend how they portrayed the landscape that they sought to occupy and to make territory for the Spanish Empire, as well as for personal interest.

[M)ore than three hundred leagues from the border of San Fernando Vellicata to the port of our father San Francisco, as also the many and good sites that offered those lands, for the formation of towns and missions, ... to convert to God so many souls that buried in the darkness of the pagans eternally perished for lack of who will teach them the true light of our Catholic religion (LeonPortilla 1970: 83).

The above account, written by Franciscan missionary Francisco Palou, provides another major objective of this first expedition for the officials of New Spain under the orders of Junipero Serra, who was in charge of the Franciscans of Alta California. Such accounts were very appealing to New Spain's governmental authorities, who provided sponsorship for subsequent expeditions to Alta California. Some of the Spanish colonial priorities focused on control of the vast fertile land and the indigenous groups, who they would convert to Catholicism and later use as a labor force. 


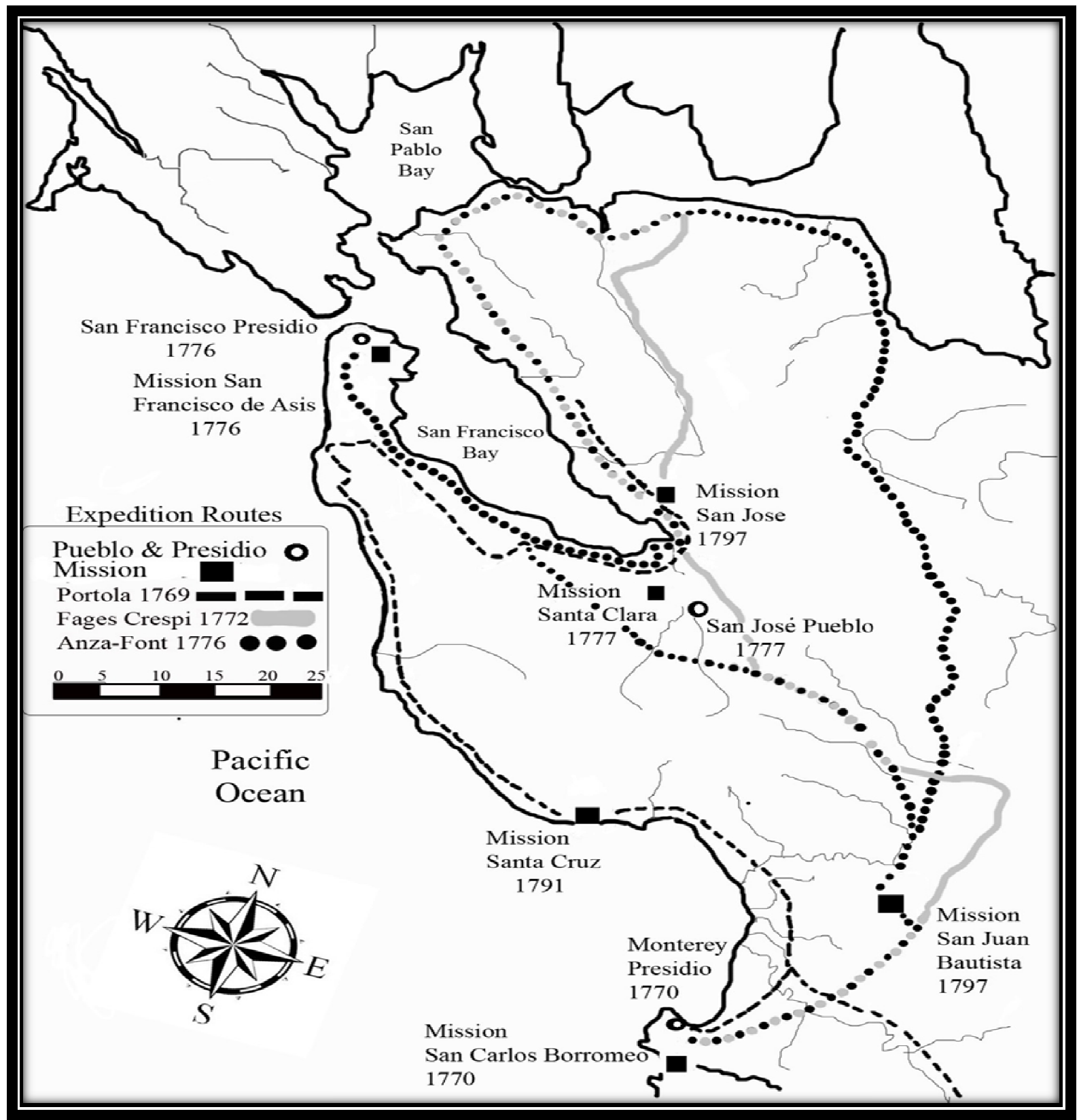

Map 3.Routes of three key Spanish incursion into the San Francisco Bay Area Between 1769 and 1776, as well as the locations of Spanish settlements through 1810 (Adapted from Milliken 1995:Map 3). 
According to Palou, the expedition was led by Gaspar de Portola from Loreto, Mexico to found the first Mission arriving the 14th of May, 1769, at the port of San Diego. At the same time these accounts resemble the caste system that was duplicated in Alta California:

This expedition was composed from the following subjects; Captain [Portola] commander, Fray Juan Crespi [which was to observe and form the diary], a captain, twenty soldiers of cuera, three muleteer and a group of Californian Indians neophytes, trail blazers, assistants of muleteer and all other things we needed, all armed with bow and arrows...traveling for fifty-two days without any casualty arrived on May 14 at the port of San Diego (Leon-Portilla 1970: 53).

Palou exemplified the first Spanish people who came to Alta California, but more importantly, the model was introduced to and imposed on the natives. This early model of social stratification in the colonial system was from the top down, with the Indians at the bottom conducting hard labor, demonstrating what was more or less a caste system. Since this was one of the last expeditions, the Spanish model obtained and utilized a refined model of conquest that came out of centuries of exploitation of the indigenous peoples of the Americas. This settlement was used to mold the Alta California indigenous peoples and to populate pueblos, missions and presidio.

One of the first examples of resistance in a manuscript was written by Palou at the time that Junipero Serra founded the second Alta California mission, Mission San Diego de Alcala. The indigenous people of San Diego illustrate early resistance to the colonist's occupation as it was noted by Palou:

... ignoring the force of the firearms and confident in the crowd of people who had arrows and wooden batons, sabers that cut like steel, and other like clubs or mallets, that do much havoc, they started to steal without any fear, and seeing that they were not permitted, they try their luck to take the life of all our people and leaving them with the spoils. So they tried to do this on the 
days 12 and 13 of August, but having encountered resistance they had to retreat (Leon-Portilla 1970: 65).

This account demonstrates that resistance by the natives of Alta California was not unheard of while it also illustrates how well-armed native warriors were against the occupation.

\section{Gaspar de Portola Expedition of 1769}

By July 14, 1769, the Spanish colonists began to move north of San Diego into Alta California. The expedition was led by Gaspar de Portola and the account that Palou wrote at the time of their arrival to the site where they placed their first presidio and mission in the Monterey Bay vicinity:

On the same day that took possession of the port was given first to Royal presidio of San Carlos Borromeo, founded the mission with the same name and next to it a palisade Church Chapel interim; also housing with respective parts or divisions by assistance from the fathers and necessary offices, both encircled for defense. The gentiles were not around in those days, because certainly the multitude of rounds of artillery and small arms that were fired by the troop caused them fear; but soon they began to approach (LeonPortilla 1970: 77).

Once the colonists began to settle, they showed off their power by firing artillery, possibly to make the indigenous people aware of their powerful presence. Several other expeditions embarked around the San Francisco Bay Area, encountering many other tribal groups. Some of these native groups seemed to welcome these "visitors," inviting them into their villages, while others were plainly not interested in communicating with the colonists, perhaps out of fear. 


\section{Pedro Fages Expedition 1770 and 1772}

An expedition was led by Don Pedro Fages with six soldiers and one muleteer in late

1770. The Fages party "established a town and mission at Monterey Bay in the summer of 1770, some eighty miles south of the Golden Gate" (Milliken 1995:36). According to the diary of Fages, they left from Monterey on November 21, 1770 and moved north towards the San Francisco Bay. The expedition went up the Santa Clara Valley and along the Fremont Plains, east of San Francisco Bay, and they retraced the path back to Monterey. The party leader Pedro Fages kept a diary in which he only mentioned native people once at a lake:

Up close to the lake we saw many friendly good humored heathens, to whom we made a present of some strings of beads, and they responded with feathers and geese stuffed, with grass, which they avail themselves of to take countless numbers of these birds (Brown and Stranger 1969:119).

Milliken (1995) states that this scene Fages describes is an interaction between the Spanish and the Tuibun people of the Fremont plain.

In March of 1772, Pedro Fages, with Juan Crespi as chaplain, led another party up through the Santa Clara Valley into the East Bay. Some of the notes from Fages' diary supply information from his second expedition to the San Francisco Bay Area. The diaries of the expedition commented upon the large number of villages on the Fremont Plain, the land of the Alson and Tuibun Ohlone-speaking tribes. Fages wrote:

Over the plain we spied several heathens, shouting out as though from at seeing us; we left five villages to our right, each of them having close to six houses of spherical shape, with considerable numbers of heathens living in them. Lying to our left hand were some villages: we could not make out very well what they were like, or how many houses were in them, since they were some way off (Brown and Stranger 1969:120) 
In this expedition the Fages party also encountered other tribal groups who invited them to take gifts as described by Crespi:

On the banks of the other side we made out many villages, whose Indians called to us and invited us to go to their country, but we were prevented by a stretch of water about a quarter of a league wide; and many of them, seeing that we were going away came to this side, crossing over on rafts, and gave us some of their wild food (Bolton 1927: 98).

As Crespi describes in this account, these tribes welcomed the Spanish as distinguished guests and demonstrated the adaptation to their environment using rafts to transport goods.

On a different account, Crespi describes the Chupcan tribal people of the Diablo Valley area of the East Bay when they encountered the Spaniards in March 30, 1772:

As soon as we entered this valley four heathen shouted at us, making signs that we should go and receive a bow trimmed with feathers, the pelt of an animal, and arrows which they had thrust into the ground. The captain went forward with a soldier and received their present, returning it with beads, with which they were well pleased (Bolton 1927; 294-295).

During this first encounter, members of these tribes and Spaniards built rapport that may have been useful in later times when Spanish settlements began to appear in the San Francisco Bay Area.

During the subsequent time from 1772 until 1774, there was a period of construction to improve the Presidio at Monterey Bay and Mission San Carlos Borromeo near the Carmel River. The California Natives had a communication network and perhaps knew what these colonists were doing during this period of construction. The colonists were getting ready for the arrival of more Spanish people coming from south of California, as well as the newly converted neophytes. 


\section{San Francisco Bay 1775 Exploration}

A sea expedition to explore rivers and inlets was led by Captain Ayala, Sail Master José Cañizares and the Fray Vicente de Santa Maria, and notes of this trip demonstrate how tribes received the Spanish as distinguished guests and one of the first accounts of illustrating that they had a ranked society:

José Cañizares said that in the entranceway by which the arm connects with them (Carquinez Strait) there showed themselves fifty-seven Indians of fine stature who as soon as they saw the long boat began making signs for it to come to the shore, offering with friendly gestures assurances of good will and safety. There was in authority over all these Indians one whose kingly presence marked his eminence about the rest (Galvin 1971:51).

During the same visit, the colonists felt outnumbered and fearful the moment they saw the powerful presence of a military force of 400 warriors come into the village:

After the feast,...the Indians, our men saw a large number of heathen approaching, all armed with bows and arrows. It was a frightening sight to those of the longboat, the Indians' advantage for an attack was so great and the resistance so slight that could be made by no more than ten men, which was all there were in the longboat's party, with barely weapons enough for defending themselves if there should be a fight...The themi (the head man), understanding what was meant, at once directed the Indians to loosen their bows and put up all their arrows, and they were prompt to obey...There were more than four hundred of them, and all, or most of them, were of good height and well built (Galvin 1971:53).

This account by Father Santa Maria demonstrates how powerful the chief of that particular tribe/tribal district was, as he instructed the warriors to put up their arrows and unstring their bows in order to show peace to the colonists. One important aspect of Father Santa Maria's journal is the social ranking within the tribe as evidenced by the chief commanding warriors, which portrays how California tribes managed confrontation and rules of hospitality by following orders by a powerful chief. 


\section{Juan Bautista de Anza Expedition 1776}

The expedition lead by Juan Bautista de Anza arrived in the San Francisco Bay Area in 1776 after traveling 1,200 miles from Sinaloa. Baustista's party included Franciscan priest Pedro Font, eleven soldiers, and seven servants and muleteers, which consisted mostly of Indians. The indigenous Ohlone people of the Santa Clara Valley at the arrival of the Anza expedition displayed opposition in at least two accounts. According to Font's diary, on March 25, 1776 the Matalan Ohlone-speaking natives' reaction to these strangers was to make them stop and listen. This expedition ultimately did not build rapport:

... although we understood nothing of what they said, and so they continued for about a league, when all but a few of them went away, then finally, little by little even these left us and we saw them no more (Shoup and Milliken 1999: 17).

The Matalans' reaction to the expedition may have shown frustration: "the Matalans may had been tired of the foreigners wandering through their lands without even stopping to acknowledge them, let alone exchange gifts and receive formal permission to go through" (Shoup and Milliken 1999:21)

During this time the expedition was not the first one exploring or passing the Santa Clara Valley (see Map 3). However, the colonists' written accounts of the Ohlone tribes illustrate different reactions: welcoming these colonists to their villages, providing them with food or gifts, and illustrating their powerful armies of warriors. Similarly, the colonists gave them gifts and food as a method to attract them into their settlements, while also firing their artillery, perhaps to show their prowess or intimidate the Natives. The natives demonstrated 
some reluctance toward welcoming the colonists; however, some Indians were more accepting than others.

\section{Mission Period from 1776-1797}

Alan K. Brown (1975) provides an illustration on how the mission's system worked after expeditions and settlements:

Each mission station was envisaged as a self-sufficient agricultural community, with the Indians living "under the church bells" in closely supervised quarters and following a strict routine of prayer, work, religious instruction, and distribution of rations. Two missionaries were protected and supported in various ways by a corporal's guard of Spanish soldiers. Overseers (Alcaldes) and other officers were chosen from the neophytes (the native converts)...There was a paseo-a "Walkabout" or vacation-for the natives, during the season of ripe seeds or acorns (Brown 1975:3).

Brown's discription discusses how these new settlements were to function in Alta California.

Once the natives were incorporated into of the Mission system, they needed a paseo (pass) to leave. At times people did not return to their mission, which was a violation of church rules because the fathers depended on indigenous peoples for their labor.

\section{Mission San Francisco de Asis 1776}

Mission San Francisco de Asis, also known as Mission Dolores, was founded on June 29, 1776. The Spanish authorities that inaugurated the Mission were Lieutenant José Joaquin Moraga and Father Francisco Palou, who arrived with the Anza Expedition of the same year. While the settlers, soldiers, and families waited for the ship San Carlos to arrive, the explorers conducted expeditions around the surrounding region to get to know the area.

During one of those expeditions Father Palou and Father Cambo went along to visit a nearby rancheria where they noted: 
The natives here are all well-formed. Many of them have beards; others are hairless and rather ugly. They are accustomed to tear out by the roots the hair of the eyebrows, and this renders them ugly. They are poor Indians without more of a house than hedge of branches to protect them somewhat against the high winds which prevail and which molest them very much. The men go entirely naked; except that they cover the shoulders with a sort of small cape pieced together from otter skins and pelican feathers. The women cover themselves with nothing but tules strung together around the waist (Engelhardt 1924:47).

A month went by and the colonists began to make decisions to move the natives to an area that was chosen by the Colonel De Anza. At this time they began the construction of a presidio and a mission, noting "that for the present there was no need to fear the surrounding pagan Indians, who really manifested a friendly spirit, determined that we two missionaries should stay where we were, protected by six soldiers, with all cattle and whatever else belonged to the Mission" (Engelhardt 1924:49).

After the establishment of the Presidio and Mission San Francisco, the Native Americans from of the nearby rancherias began to visit. However, the Spanish had no way of explaining to the natives their purpose. Fray Palou stated that "apparently they rejoiced at our coming, although, for want of an interpreter, and we ignorant of their language, the reason for our appearance could not be explained to them" (Engelhardt 1924:59).

On August 12, 1776 a battle began between two rancherias, which resulted in the larger rancheria's relocation near the presidio. In December of the same year, a group of Indians visited and started to resist the colonists at this rancheria, where "they grew so insolent as to steal, to aim arrows at the corporal of the guard, try to kiss the wife of a soldier, and endeavor to shoot an arrow at a neophyte from Mission Carmelo" (Engelhardt 1924:59). 
In this instance, the indigenous people began to rebel against these new colonists as their relationship became violent. The natives of the surrounding areas came to visit again, and the "one who had a few days previously threatened the life of the neophyte, ordered him arrested and given a few lashes in the guardhouses" (Engelhardt 1924:59). In another incident on the following day, the sergeant and other soldiers went to look for the Indians that were responsible for shooting arrows towards them and later located them. In a correspondence it was noted that:

The sergeant dismounted. When they saw the move, the two culprits fled, but two of the soldiers followed them. The other Indians then turned upon the soldiers and began to shoot arrows with result that a settler, who had come without the leather jacket, was slightly wounded. A horse was also wounded, though not seriously. When the sergeant saw this, and the Indians would not cease shooting arrows, he commanded the soldiers to discharge their muskets. The wounded settler himself shot one of the Indians, who fell dead in the waters of the channel...From there they continued shooting arrows...they pleaded for peace by throwing their bows and arrows to the ground (Engelhardt, 1924:61).

These two Indians were captured, flogged, and told to get out of the mission. They were then not seen until March 1777, when "gradually, attracted by presents and food, as Fr. Palou remarks in the Vida, they yielded, so that on the feast of St. John the Baptist, June 24, 1777, the first three converts, who were adults, were baptized, and did not any more associate with the gentiles" (Engelhardt 1924:61). The founding of the Presidio and Mission San Francisco started to attract some Indians and so began to be populated. However, the resistance began to emerge in the region surrounding Mission Dolores which involved some of the unbaptized Indians against the colonists and neophytes. 


\section{Mission Santa Clara de Asis 1777}

Father Tomas de la Peña founded Mission Santa Clara de Asis “on January 12, 1777 (Hoskin 1961:21). This mission was the second or possibly third mission that was founded after the arrival of the Portolá Expedition in 1769. The vessel San Carlos had on board much of the material needed to establish the missions. The new settlers left the San Francisco Presidio, which had included nine Spanish soldiers, together with one colonist from Mexico and one Franciscan missionary to the broad Santa Clara valley. Father Jose Antonio de Jesus Maria de Murguía described the surrounding areas "pleasant to the appearance with the extensive lands for wheat planting and well suited to stock breeding” (Milliken 1995:65).

The first baptisms took place in Santa Clara Mission on June 6, 1777 (Hoski 1961:36), almost one year after the new explorers came north. At this time an epidemic was going around the Santa Clara Valley, killing one or two year old infants in the local villages.

Cook noted from the Spanish archives that in:

May, of the same year [1777] the first baptism took place, for as there had come upon the people a great epidemic, the Fathers were able to perform a great many baptisms by simply going through the villages. In this way they succeeded in sending a great many children (which died almost as soon as they were baptized) to Heaven (1976:18).

As these first baptisms were taking place, the indigenous people of these villages may not have known what the fathers were doing to their infants since at that time the colonists could not communicate with the Natives due to language barriers.

In the same year near Mission Santa Clara, the pueblo of San José de Guadalupe was founded by fourteen families from New Spain/Mexico on the eastern bank of the Guadalupe River. This pueblo, according to records, was located among three tribes who resisted the 
presence of these people; however it did become a source of opportunities for the native peoples in the subsequent periods. As the pueblo was established, it was seen by colonists as a place to provide an alternative source of Spanish material goods, as well as to aid the soldiers as they settled in this outpost of the Spanish frontier.

\section{Mission San José 1797}

Father Fermin de Lasuén founded Mission San José (see Map 4) on June 11, 1797. During the morning of June 9, 1797 a group of soldiers from the Presidio of San Francisco and neophytes from Mission Loreto (Mexico) traveled left from the Mission Santa Clara to found Mission San José (McCarthy 1958:47). From this site, according Father Lasuén, one could "see that the acres immediately below the plateau would best serve as fields for grain and corn.... and easterly to the general neighborhood of Mount Diablo offered teeming acres

of rich pasturage for the cattle" (McCarthy 1958:48). McCarthy in his study on the history of Mission San José also noted:

The Baptismal Register bears concrete evidence of the zealous labors of the young missionaries during the first six months of the ministry, when it records from September 2 1797, to January 1, 1798, the christening of nineteen Indian men and fourteen Indian women. The entries reveal that these converts had been won variously from tribes "from the east,' 'from the north,' 'from the south,' 'from the Alameda,' 'from the Redwoods,' and 'from the Estera,' the salt marshes' (McCarthy 1958:60).

Eventually many East Bay Ohlone and later neighboring Bay Miwok, North Valley Yokut and Plains Miwok-speaking tribal groups came under the influence of Mission San Jose's outreach (see Map 4) 


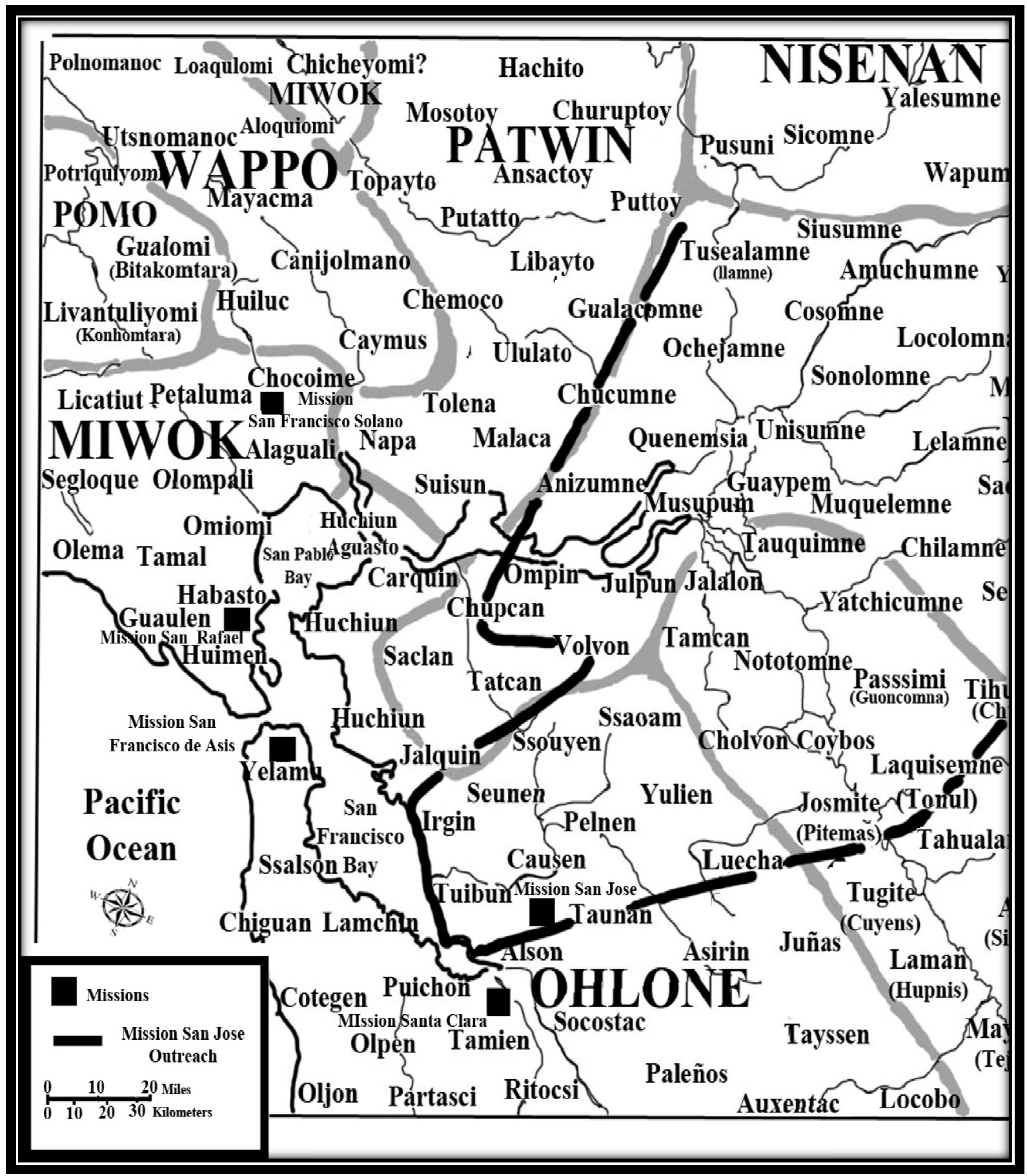

Map 4. Map of Mission San José Outreach Area. (Adapted from Milliken 2008: Figure 1). 


\section{Post Mission Period 1797-1824}

During the late 18th century the Bay Miwok-speaking the Sacalanes and Chocheño Ohlone-speaking Cuchillones (Huichun) tribal groups of the East Bay resisted the colonial indenture and some of these neophytes fled Mission Dolores to return to their villages. These fleeing neophytes were a catalyst that contributed to the persecutions of converted Indians at Mission Dolores by other neophytes headed by "Raimundo, a Christian Indian from Lower California, with thirty neophytes, (who) had secured the San Francisco Mission Padres' permission and crossed the bay to seek their return" (McCarthy 1958:63). However, as Raimundo had tried to convince the neophytes to return to the Mission, the runaway converted Indians decided not to get on the balsas (canoes) and return. Instead these neophytes resisted and decided to join $\mathrm{t}$ their fellow Indians who were dancing and their fellow tribal members came "on the scene to aid them in their resistance" (McCarthy 1958:63). As a result of this particular tension, the mission fathers and governmental authorities decided to muster a stronger expedition against Sacalanes (Saclan) and Cuchillones Indians.

Father Espi's plan to capture the runaways and bring them back to the mission by talking to them was overruled by the argument of the Sacalanes and Cuchillones, who believed that the Spanish were afraid of them. Alferez (a second lieutenant) Amador "advocated immediately sending a strong armed force into their midst in order to dispel that illusion in their minds" (McCarthy 1958:65). At this time, Diego de Borica was the governor, who agreed with the argument that the Alferez Amador had made against the 
Sacalanes and Cuchillones back by the rumor of their "plans to attack the infant Mission of San José" (McCarthy 1958:64).

The expedition to battle the Sacalanes and Cuchillones (Huichun) took place on July 13, 1797, leaving from Mission San José. The Spanish archives note that "Corporal Vallejo, twenty soldiers, and two Indians guides were assigned to Amador's command for the expedition" (McCarthy 1958:64). The expedition arrived first at the Rancheria of the Sacalanes where they encountered resistance:

We entered their village, only to meet great resistance from the Sacalanes. Much as we tried to tell them that we did not wish to fight them, but that we merely wanted to take away the Christians, they would not listen to any of our assurances whatever, but began an attack on us, killing one horse, and wounding two others. Seeing that they were out for battle,(we) were obliged to use our arms to make them surrender. Although we killed seven of them in the skirmish, yet, after more than two hours of fighting, they still would not give up. There were only about fifty Indian men and women engaging us...they had dug trenches in the center of their village, as fortifications for attacks against us,...we found it necessary to dismount and to fight them hand to hand with our swords and lances before forcing them to surrender (McCarthy 1958:65).

In this battle these Native warriors did not give up while protecting the Christian members of their tribe, even forcing the soldiers to use other modes of attack. This illustrates how the indigenous people of the area were determined to fight and die to save their tribal members from being captured.

This expedition afterwards continued, and they were attacked on the way to the Rancheria of the Cuchillones. The warriors confronted them, which resulted in capturing a couple and killing one, and the rest surrendered. Once they arrived in the territory of the Cuchillones, they captured the rest of the "ringleaders of the attack which (had) been made 
the month (before) upon Raimundo and his band of Christians" (McCarthy 1958:66). The expedition ultimately took "seventy-eight Christians runaways, together with nine pagan and five Christian ringleaders of the recent disturbances" (McCarthy 1958:66). All of these neophytes and prisoners were taken back to Mission Dolores, and some were sentenced to labor in San Francisco Presidio. (McCarthy derived these accounts from the Miranda to Argüello correspondences, June 29, 1797. Archives of California, Provincial State Papers, XVI, 90. Pedro Amador's diary, Amador's "Prevenciones.").

After the military expedition was successful and forced the Sacalanes villages to surrender, they moved to their next target, the Cuchillones villages. Amador describes their next battle:

There were three other villages in the neighborhood, he continues, but their inhabitants, hearing the noise of the battle, took to their heels. From one of them, however, we captured two Indians. In that first battle we had captured thirty Indians, some of whom were Christians. Holding in custody these Christians, as well as a few pagan leaders of the insurrection, WE FREED THE REST OF THE PAGANS. We first reminded them, however, that it was wholly their own fault that all this suffering had befallen them and we told them again that we certainly had not come to harm them. They left at once in the direction of the territory of the Cuchillones; however they had not gone far when they were reinforced by a great throng of hostile Indians......but after we had killed another of their band, they all retired from the conflict (McCarthy 1958:65).

In 1799, Father Junipero Serra wrote to his friend Reverend Fray Fermin Francisco

Lasuen. He wrote the letter to relay Governor Felipe de Neve's instructions on how the Native Americans should choose an alcalde in order to better self-govern themselves. Serra believed that this new order could undermine the mission's power over the Indians.

Let Francisco, with the same staff of office he uses and his coat, be the first alcalde. All we have to do is to change the name. Another alcalde might be 
the chief from one of the Rancherias, of those that visit the mission every fifteen days, as for the regidores, who carry not staff, let one be from that Rancheria, and the other from another. Whether they be chiefs or not is of little importance, but it is better if they are. In this manner everything will be settled without causing any great upset. For that purpose, much help may be derived from the manner in which the Lieutenant explains to them their various functions when he installs them into office...Ask him to carry out this function so that, without failing in the slightest degree in his duty towards his superior officer, the Indians may not be given a less exalted opinion of the fathers that they have had until now (Beebe 2001: 220-221).

Serra's assumption about possible disempowerment of the missions was a prediction that would come to fruition, for as time would later tell, several of the alcaldes did take up arms against the missions, presidios, pueblos, and ranchos. Furthermore, Beebe states that one of the issues that governor Neve and Junipero Serra fought over was about the indigenous people's role in the Mission communities. They debated whether to bring in a self-governing Native American mission population and transform them into Spanish citizens. Serra's letter to Lasuén expresses his fearfulness and his way of manipulating the situation in regards Neve's request. The mission fathers had to identify tribal representatives to serve as leaders; these leaders would become alcaldes or regidores.

However internal problems were rising between and within their own colonial system, which was beginning to manifest as early as 1801. A letter sent to the Commissioner of San José de Guadalupe from Monterey and signed by Raymundo Arriaga stated:

The Lieutenant of the frigates Don Ramon Sandolera, Commandant of the ships of the king of Spain, has requested officially as the $6^{\text {th }}$ day of the present month that we supply his ships with one thousand arrobas (or 25,000 lbs. of flour), because they did not take on enough flour at San Blas to last them one hundred days. Please make it known to all the inhabitants, principally to those who owe taxes to the government and have them bring in at this port as much 
flour as possible to supply the request of the ships commandant (Arriaga

Letter to the commissioner of San José de Guadalupe, August 11, 1801).

The Spanish crown during the early 19th century pressured not just the citizens of the pueblo, but others as well. Since Native Americans were part of the labor force, they may have had an impact on their lives of the citizens at the pueblos, presidios and missions. Subsequently, another letter demanded as a follow-up to the earlier request for flour. This portrays the conflicts between civilians and military agents of Alta California because they owed taxes and did respond to the orders to provide flour to the ships of the King of Spain.

The colonial authorities issued edicts as signs of trouble emerged between the citizens and Indians in the pueblo of San José. This led to the construction of the first jail in San José by a request sent by Raymundo Arriaga stating "I want to serve the laws of the King of Spain and remove the fear of the town people for the bad elements, you must built a jail and all those who are sentenced are to be secluded in security" (Arriaga letter to commissioner of San José de Guadalupe, February 20, 1802).

Cook (1976) notes that the indigenous people were developing strategies for leaving their villages because fear of the colonists' tactics which were disrupting their environment and their subsistence. The desertion of Native American villages was ongoing after 1805 . Cook states:

The approach of any white was marked by wholesale flight on the part of the natives. Large numbers of Indians were prone to vacate their villages and betake themselves to some point of safety, leaving many of their possessions to be looted. An isolated affair of this sort might not be followed by fatal consequences. The inhabitants, after the strangers' departure, could return and take up their life where they had left it...their food-gathering, their hunting, their domestic industries for a matter of days, perhaps weeks-to the inevitable detriments of all these pursuits (1976:25). 
José Maria Amador, a soldado de cuera (Soldier), relates an account about an expedition that took place out of Mission San José to Christianize the indigenous of the Rancheria of the Ohlone-speaking Luechas:

Rancheria Los Loechas (Luechas), located about fourteen leagues east of the Mission, above the present town of Livermore, at the distance of some four or five leagues. At the arrival of the priest and the soldiers, the Indians rose up in arms against them. They wounded with (arrows) the father, some of the soldiers, and the foreman Ignacio Higuera. This Mr. Higuera defended himself until he finished all his ammunition; the Indians captured him alive and killed him with arrows. After he died they cut off his two hands and they scalped his hair (Mora-Torres 2005:41-43).

The survivors of this expedition returned to the mission to report the incident. Lieutenant Gabriel Moraga then returned to the rancheria to capture those responsible for the resistance and killing. However, "these (Indians) had moved to the San Joaquin River to a rancheria called Los Pitemes. After a small skirmish, they quickly captured the Indians, including men, women, and children" (Mora-Torres 2005:43). Once they were captured, some were taken to the mission and the rest to work in the presidio.

The Native tribal groups seemed to have developed an awareness of the movements of some of the expeditions that took place. There were times the Natives were welcoming, times they were unwelcoming and resisting, and other times that they fled. Records demonstrate that from 1809 to 1819 , there were

thirty instances mentioned when the natives were present in their villages and received the white men in friendly fashion....thirty two cases when the village in question was practically deserted, owing to the flight of the inhabitants, or when some of the Indians were present but were hostile (Cook 1976:26). 


\section{Indians as a Transformed Peon Labor Force and the Economy of the Missions}

The Indians that arrived at the mission were introduced to "an extremely paternalistic system in which the Indians were treated as eternal children" (Shoup and Milliken 1999:52). The Indians were also taught the religious ways of the Catholic religion. However, language barrier was problematic, as Shoup and Milliken state that "It must have been very difficult for the Indians baptized during this period and later to comprehend that by this act they were henceforth to be required to live and work at the mission forever except when the padres gave them passes to leave" (1999:39). The daily routine of a neophyte involved religious activities and work which revolved around the bell of the mission:

That the task of the bell-ringer was an important one is readily seen, for records state that the mission Indians were governed for worship, for labor, for meals, and for sleep by the sound of the bell. The Indian's day began at sunrise when the Angelus bell called them to prayers in the mission church. About an hour later another bell announced breakfast, whereupon each family sent to the community kitchen for its share of the food that had been prepared. After breakfast another ring of the bell sent all who were old enough and able to work to their appointed task. There were no laggards in this community. From the small boy who scared birds away from the orchard or straying animals from drying adobes to the little girl who helped prepare the wool for spinning, and the old woman who gathered wood for the kitchen fires, all who were able to work had some special task to perform. In the forenoon and again in mid-afternoon, one of the Padres gathered together all the children over five years of age and instructed them in the Doctrina. Following the morning period with the children the Padre visited the fields and shops to see that no one was absent to work. Shortly after eleven o'clock, the Padres had their noonday meal. From twelve until two o'clock the Indians ate their meal and enjoyed the inevitable siesta. Then back to work they went until about five o'clock when it was time for prayers and devotions. At six o'clock came the ringing of the Angelus. Supper was then served. For the remainder of the evening until Poor Soul's Bell was rung at eight o'clock, the Indians were free to do as they wished within certain limitations, of course. Thus it was that day after day, week after week, and year after year, the life of the mission community was regulated by the ringing of a bell (Shoup and Milliken 1999:41). 
It seems, then, that the typical day at the Mission was very structured, with the Indians not having free time until 8:00 at night.

At the same time, Indian labor at missions grew, creating a surplus. For example, Mission Santa Clara, like other missions of California, started to "grow the main crops of wheat, corn, peas, vegetables and fruits" (Shoup and Milliken 1999:52). Labor was part of the colonial system that depended on the natives (Cook 1976; Milliken 1995; Hurtado 1988; Wolf 1959, 1982). Hurtado states "the Franciscan establishments became the paramount economic institutions of the colony, controlling most of the land and an Indian labor force of many thousands" (Hurtado 1988:24).

The missions and towns were centers of production. During the year many distinct seasonal activities took place on the mission properties, which can be seen in a recollection by Nasario Galindo. He was born about 1810 and the son of Leandro Galindo, who was a majordomo at the Mission Santa Clara during this period:

Every year, in the months of June and July, the calves that had been born that year were branded. There were times when 10,000 head were branded, other times about 8,000. During the winter, many calves, sheep and horses were found dead, killed by coyotes and wolves. Before the beginning of the winter, all the sheep were sheared and the wool was woven on the looms to clothe the Indians, and soon as November arrived, all the big and little children also clothed.... Some of these storehouses were about 500 varas in length and about 50 varas in width and contained wheat, barley, corn, beans, lentils, garbanzos and horse beans... Indians also were taught to take care of the orchard, supplying the priests with fruit when it was ripe (Shoup and Milliken 1999:54).

This account by Galindo demonstrates how labor intensive life was at the mission; this allowed for the mission to create their wealth through cattle, grains, and fruit crops. 
The cattle industry was also an important activity in all missions, which "became more and more important and reached into every corner of mission life" (Shoup and Milliken 1999:54). This season was called the matanzas (slaughtering season). Cattle provided a key source of protein at the missions and the hides provided an income "which they bartered with trading ships from New England especially for many items that the padres wanted for the mission and the Indians" (Shoup and Milliken 1999:54). The mission used the Indians to carry the hides on their heads to the embarcadero. As Shoup and Milliken note:

But often in winter, there being no roads across the valley, each separate hide was doubled across the middle and placed on the head of an Indian. Long files of Indians, each carrying a hide in this manner, could be see trotting over the unfenced level land through the wild mustard to the embarcadero, and in a few weeks the whole cargo would thus be delivered (1999:55).

Economic activities involving Indian labor included the "production of fabrics, soap, blankets, saddles, tanned hides, shoes, and tallow" (Stodder 1986, as cited in Shoup and Milliken 1999:55). At the same time Native Americans took on the construction of buildings of the presidios, pueblos, and missions. As a result it can be ascertained that the colonial system of Alta California depended on the labor of Indians for the production of merchandise that was used interregional and for export to Russian, English, American, and Spanish vessels off the coast (Shoup and Milliken 1999:55). This way of using Indians as indentured labor created a reaction not just from officials of the pueblos and presidios. From the mission perspective,

the missions were protecting the natives from secular exploitation. They were at least making some small attempts to integrate them into a new culture and society. From the perspective of most Indians, however, the entire colonial experience was a complete disaster because people were uprooted and forced to work on colonialist projects, and because so many died (Shoup and Milliken 1999:60). 
The revolution of 1810 in Mexico resulted in hardships for the California military and governmental institutions. "The decade 1811-20 was in New Spain and many other parts of Spanish America a period of strife growing out of the revolution by which the colonies sought to throw off the yoke of Spain" (Bancroft 1886:194). One way that it affected Alta California had to do with the yearly arrival of ships that had carried merchandise, other goods, and money which no longer came, and the "soldiers received no pay" (Bancroft 1886:195). Therefore the people of Alta California had to adopt other modes of survival. Since merchandise from Mexico did not arrive, the California military had to depend directly on the mission's products on credit.

Starting in 1814 , each mission was required to provide the local presidios with supplies of flour, clothing, blankets, and shoes. In addition to the demands of the local presidios, the governor of Alta California required the missions to provide large quantities of grain, tallow, and hides, for which they were supposed to be paid back by the new Mexican Government (Stickel and Cooper 1969:13).

Mistreatment of the Indians by the Spanish priests could sometimes result in the natives resorting to violence. According to Mora-Torres, there were priests were "alcoholics who would ruthlessly beat the neophytes" (2005:18). In 1812 the neophytes of Mission Santa Cruz orchestrated a plan to kill Father Andres Quintana. According to Lorenzo Asisara, a neophyte and singer of Mission Santa Cruz, his own father was one of "those who conspired to kill the Father" (Mora-Torres 2005:79). Asisara stated that "all of them go together at Julian's house so that they could discuss how to prevent the further cruel punishment that Father Quintana inflicted on them" (Mora-Torres 2005:81). These 
neophytes eventually killed Father Quintana, although they were not caught until years later, when they were sentenced to 50 lashes each and public service (Mora-Torres 2005:95).

During 1824 tensions arose in the Chumash people from the Santa Barbara region, south of the San Francisco Bay Area, Archaeologists E. Gary Stickel and Adrienne E. Cooper wrote a study about the Chumash Indians of three missions that orchestrated "the only revolt in California mission history" (Stickel and Cooper 1969:12). The missions involved in this revolt were La Purisima Conception, Santa Ines, and Santa Barbara. Stickel and Cooper discussed the stresses that at this time the Chumash Indians were under which had to do with the economic processes demanded by the mission colonial system:

Demand reached critical proportions some thirteen years before the Chumash revolt, with the Mexican Revolution against Spanish authority. When Mexico succeeded in cutting her ties with Spain she found herself unable to provide the economic or the moral support on which the missions and military presidios had been dependent. Without their stipends and supplies from Spain, the military and missionary alike were forced to maintain that input in some compensatory way. Because the missions were fairly self-supporting, the military readily turned to them for help (Stickel and Cooper 1969:13).

Adding to these stresses, Stickel and Cooper mention that the presidios relied on support from the missions for their "supplies of flour, clothing, blankets, and shoes," all of which were produced by the Indians (1969:13). In addition, the Mexican government "on April 12, 1823, and imposed a $6 \%$ tax on all mission exports (except brandy)...on January 7,1824 , an additional tax of $12 \%$ was levied on all mission produce and goods" (Stickel and Cooper 1969:13). Stickel and Cooper add that on top of all these stresses to the "Chumash sociocultural system was the decimation of their populations by disease" (1969:13). These burdens 
were no different in the missions north of the Chumash region, since the same colonial system was also enforced.

As pressures and tensions arose, Indians resented their indenture at the missions. Over the years as a response to these arduous and untenable conditions Native American leaders emerged from several of the San Francisco Bay Area Missions. Several of these leaders include Pomponio, Estanislao and Yozcolo who were themselves alcaldes at their respective mission. This contextual background is important to consider up to this point because it sets the stage for the analysis of these three Native American leaders and into context and their response and resistance to the stresses and structural violence that the colonial system brought upon the California Natives. 


\section{CHAPTER 3: THEORY}

\section{Introduction}

This chapter discusses the theories that were considered on this research project. A multi-theoretical approach was employed in order to develop and argue an alternative perspective on the historical response, resistance and ensuing persistence of the San Francisco Native Americans to colonialism. This alternative perspective spans several time periods ranging from 1) the post-1769 Spanish Empire expeditions and colonial settlements including a discussion of their arrival (entradas), exploration, missionization of the native population and development of pueblos; 2) the creation of the Mexican Republic in 1821;

and 3) following the Bear Flag Revolt and American Conquest 1846-1850. It is important to note that the adversarial relationship between the colonized Native Americans and settler elites (Californios) continued as tensions and conflicts arose and spilled over after 1846 when the United States took possession of Alta California.

First formulated in the 1960s and 1970s, the theory of political economy (e.g., Asad 1974; Mintz 1985; Roseberry 1989; Wolf 1982) can provide a framework to consider alternative histories. Applying a political economy and world systems approach (Wolf 1982) to the San Francisco Bay Area of California while employing critical data within an anthropological and historical framework in order to understand world economy tensions sets the stage to explore the deeper meanings of relationships between natives and colonists. Another theoretical perspective considered in this study is Stephen W. Silliman's (2001) theory of labor, as well as James C. Scott's (1985) notion of "weapons of the weak," which debunks assumptions of passiveness in peasant societies by analyzing everyday forms of 
resistance. Another scholar, Felipe Castro (1996), has attempted to include the perspective of Native American history, as have others like Kent G. Lightfoot (2005), an archaeologist who has focused on the material culture of the Franciscan missions and the Russian Fort Ross, identifying indigenous patterns of social agency of the Native Americans. Lightfoot (2005) notes that as more intense raids on the pueblos occurred, secular and ecclesiastical institutions negotiated their own interests. Futhermore, following Indigenous archaeology approaches from Wilcox (2009), Panich (2012) and Cambra et al. (1996) show persistence through a new narrative that argues against the terminal narratives that historians and other disciplines have utilized to explain history. In short, an urgent reexamination of the histories of indigenous peoples is clearly needed.

\section{Alternative Perspectives on History: Political Economy and World-Systems Analysis}

Anthropologist Eric Wolf (1982) employs political economy and world systems theory to expose misconceptions about how history is perceived and constructed by dominant societies at large. Wolf argues that we have a basic knowledge that we all exist in one world, where we are ecologically, demographically, economically, and politically entangled. Such a view of the world helps us to understand past experiences or relationships. Wolf (1982) states that many anthropologists, historians, and other social scientists (especially those in European or Euro-American countries) have the idea that civilization can be traced back to the Greeks. The Greeks, he states, influenced Rome, with Rome then influencing Christian Europe. Christian Europe in turn produced the Enlightenment, and the Enlightenment influenced political democracy and the industrial revolution. Industry combined with democracy to yield in the United States the embodiment of the rights to life, liberty and the 
pursuit of happiness (Wolf 1982:5). Wolf argues this is an ethnocentric view of history: an endless series of transformations or transitions, largely propelled by the actions of European protagonists (conquerors, Christian missionaries, and commercial agents in particular).

This view of history creates the idea of a moral purpose "of how the winners prove that they are virtuous and good by winning" (Wolf 1982:5). However, this approach to history fails to acknowledge the complex series of relationships that exist among humans. These relationships include a fusion of inter-relationships operating within systems of exchange, status, inequity, and power. In other words, looking at history in a linear fashion is less of a study of social history than it is a model to tell a story of moral success, justifying Western dominance and implying that Europe (and the "West" more generally) have history-while the rest (indigenous peoples, slaves, and non-Western others) do not.

If we see history as a tale of unfolding moral purpose, those that are linked to the colonial genealogy believe that they are a superior class. As Wolf states, if history is perceived as the "final apotheosis and not a manifold of social and cultural process at work in their own time and places," the scheme presents a misleading understanding of history (Wolf 1982:5). Many social scientists have failed to understand how all of our histories are linked together with the development of capitalism on a global scale. For Wolf (1982), capitalism has a stubborn tendency to polarize wealth and power and to distribute them unequally. A perspective of political economy is that capitalism itself is a global culture that shaped the interconnected histories of colonizers and colonized, capitalists and workers, the West and the rest. Political economy also explains that capitalism, even more than colonialism, was the driving force at work. In seeing how the relationships between the colonizers and the 
colonized are developed by the contribution of other external forces, history can be viewed with a different lens that allows for a more holistic view.

\section{World-Systems Approach}

Immanuel Wallerstein (1974) uses anthropological and regional history to trace the origins of the capitalist world-system and the development of what is called the European world-economy. The goal of this approach is to analyze aspects of the world economy and the origins of global inequalities. Wallerstein notes that global economy began in the late 15 th and early 16th centuries and effectively divided the world into core and periphery regions in which the core nations (Europe and America) garnered profits from the periphery nations (the rest of the world) (Erickson and Murphy 2003:149). An international division of labor was formed in the wake of this world economy. Wallerstein demonstrates how, through the evolution of capitalism, the core and periphery relationships are connected and at the same time differentiated. Wallerstein's (1974) main focus is on the capitalist aspect of the world system and its components, but such a method had to capture the history of the core countries, showing how the core had hegemony over the periphery.

The world system approach shows how larger forces at the global level interacted and transformed the world of today. Wallerstein's (1974) approach states that a core country has hegemony over the peripheries. However scholars like Gil J. Stein (1999) have argued that although the world-systems approach is remarkable, it lacks the perspectives of the peripheries, in which individuals or communities have agency to establish their own interregional economic model. The interregional approach is "one of the primary models used by historians and archaeologists to explain the expansion of social complexity from 
early urban or territorially base states in 'core' areas outward to less developed polities in neighboring areas, which they label "peripheries"' (Stein 1956:3). Colonial European expansion cannot be seen without first understanding capitalism and how the peripheries' external and interregional interactions play a role in the economy.

\section{Labor Theory}

Many scholars have worked on piecing together a history with a holistic perspective, providing information about how Native American populations resisted colonialism and how they survived. One example is Silliman (2001), who claims that the labor of the mission system brought a structural plan to the Alta California region and drastically changed to native peoples' daily lives both inside and outside the mission walls. Colonialism created relationships between indigenous people and colonists at different times and localities. These relationships brought change in the social dynamics of various activities, including creating a labor force to sow, harvest, and make products such as tallow, hides, or clothing in finishing products (Shoup and Milliken 1999; Silliman 2001). The workers and the landowners had a reciprocal relationship and were all dependent on each other at times for various needs of survival.

The Spanish model of producing commodities in the Alta California region functioned with the help of at least these three major components: land, labor, and a system of control which served to implement and teach the Spanish lifeways and punish those who were disobedient (Wolf 1959). Stephen W. Silliman (2001) states that there are few cases in which scholars have researched historical accounts of Native American labor during mission times. By employing the assumption that colonial imposition included a strategy of 
discipline and a "locus of social agency and practice" (Silliman 2001:380), scholars can proceed to consider alternative historical perspectives. Theories of practice and labor can be applied in a different way; not as an economic phenomenon, but rather as conceiving of labor as a practice and as social agency. This perspective offers an alternative way to examine histories associated with the missions other than what previous work has provided. This particular lens can be used to see and understand colonial processes as imposing alien economic systems in places like the missions, pueblos, and presidios. This resulted in the transformation of the indigenous people's way of life since the Spanish model of production required Indian labor to function and sustain colonial settlements.

Silliman states that "some individuals undoubtedly acquiesced to labor regimes, while others resisted it in their everyday activities" (2001:385). Labor practices during colonialism in Alta California added to the theoretical model that Silliman applied in his research on native labor in colonial situations. He asserts that we need to take into account both sides of the experience, using the top-down perspectives to analyze "the view of labor as production and form, the imposition of labor on native workers and the discipline of labor regimentation-- and the bottom up perspective- the recognition of labor as something experienced and the politics of subversion, acceptance, and redefinition" (Silliman 2001:384). This allows for new perspectives to emerge that are key to understanding aspects of the survival (adaptive strategies) and continuity of cultures.

The analytical anchor of Silliman's (2001) argument is that labor was a, if not the, primary experimental base of Native American participation in the missions. With this assumption it becomes clear that the top-down perspective allows us to view labor through 
"historical documents, ethnohistorical observations, and oral accounts, but archaeological research is usually required to see its manifestation in daily social life or from the bottom up" (Silliman 2001:384). This bottom up view "can also begin to illuminate the bottom-up viewpoint: negotiation of labor relations, daily practices of labor, and social agency of those engulfed in the colonial labor regime" (Silliman 2001:386).

In recent years, many have turned timely attention to questions of native resistance and social agency. Silliman asks about how daily work practices became the norm, how they were forced onto the new population, the extent of the division of labor, and the operationalization of labor. To these Silliman (2001) poses the question: What did labor mean for native identity, social relations, and those individuals performing it? After all, the natives had used a different ecological system of land management strategies and agriculture processes that were severely altered by the new colonial regime.

The Spanish model was implemented by gaining support from converts. Natives were converted to Catholicism, then required to labor in the mission trades to produce materials. These were then used for mission supplies and for intra-mission trade and distribution. This labor system of the Franciscan missions has been described as communal (Cook 1943c:47, Silliman 2001:387). The relatively easy access to the Pacific Ocean, where the presidios used their agency to trade with merchants by ships and later by land to the south and the east, was a strategic aspect of the colonial system. These new contacts with the outside world brought other opportunities to the Californios, and in turn, these new interactions had an effect on the Native population. 
It is understandable that some of the Native American populations voluntarily chose to work in the mission system. However, Cook argues that "(d)espite innumerable lamentations, apologies, and justifications, there can be no serious denial that the mission system, in its economics, was built upon forced labor" (Cook 1943a: 95-96; see also Jackson and Castillo 1995: 44; Jackson 1994:135; Guest 1979; Silliman 2001:387). Hard labor was forced upon natives as punishment as well; this "occurred only in conjunction with imprisonment that increased over the years until 1831" (Silliman 2001:387). The colonial system, then, needed this forced labor to sustain its economy.

\section{Indigenous Archaeology: A New Way of Deconstructing Mythology}

Indigenous archaeology is an approach that brings a new perspective to Native American history by weaving together the history that was fragmented with the arrival of the European colonial powers and thus is often ignored in our contemporary history (Lightfoot 2005; Silliman 2001; Panich 2012; Wilcox 2009). Through indigenous archaeology, Native American scholars such as Michael V. Wilcox and Sonya Atalay are able to contribute to academic discourse about colonialism and Native American perspectives.

Wilcox (2009) applies indigenous archaeology to the history of the Pueblo peoples of New Mexico by integrating historical accounts within an anthropological framework to provide a means to interpret history that was never documented. He utilizes Eric Wolf's (1982) political economy and world systems approach. Wilcox (2009) further states that indigenous histories can illustrate asymmetrical relationships of power as the imbalance between the perspectives of the colonizers and the colonized obscures the presence and cultural persistence of indigenous people. 
Wilcox's primary attempt was to develop a different kind of archaeology to capture a holistic history of the Pueblo peoples by reexamining and performing translations of primary historical accounts of expeditions, or entradas. He emphasizes the terminal narratives created by historians and anthropologists that have contributed into making an "invisible Indian" (2009:13). A considerable amount of history has been written by Europeans, who told of their experiences and actions towards indigenous peoples and in some cases how the indigenous peoples acted towards them. However these accounts hardly include historical perspectives of the Native societies.

Spain acted as a global enterprise, gaining wealth and tributes to support the Spanish crown, and creating from the indigenous peoples and their lands centers of productions called missions, presidios, pueblos and haciendas. They were aided by the work of the Franciscans and military personnel. The primary documents consist of the dialogues of the top administrators, military personnel, and ecclesiastical devotees, who wrote their experiences, often exaggerating what they saw, as Wilcox's analysis demonstrates. Reexamining those dialogues of history is important as it can reveal colonial mythologies of colonization of indigenous peoples of the Americas and explain their existence (Wilcox 2009).

Wilcox (2009) demonstrates that when historians focus on the triumphant narratives of the Spanish conquest, they forget to focus on the cultural dimensions of the indigenous peoples, instead putting them in the background of history and making them seem unreal. Hinting at a peaceful process of integration to the new culture, historians also tend not to focus on violence and conflict by choosing to paint a "bloodless" history (Wilcox 2009:234). According to Wilcox (2009), this treatment tends to be a familiar narrative that has been 
adopted by the historians that have studied the bardic style from the models that come from Hubert H. Bancroft (1886) and Herbert Eugene Bolton (1930).

This model of research, the terminal narrative, focuses only on certain aspects of acculturation and disease models to explain what happened to the natives, conducting and portraying their research as if the Native peoples had completely disappeared. Wilcox states that with "the dominance of 'disease and acculturation models' of the post-contact period (there) has been a lack of scholarly attention paid to the subjects of conflict, violence, and resistance between colonists and Native peoples through extended periods of time" (2009:17). The reexamination of the Spanish primary documents and secondary sources, combined with archaeological data, from sites that pertain to the years of the revolt of 1680 , generated new perspectives on the Pueblo colonial experience by piecing together Spanish primary documents that have been translated into English. By critically analyzing these primary documents, Wilcox uses nondestructive methods and historical materials to challenge acculturation and demographic collapse models which do not accurately explain history. Wilcox's research and methodology reveals that Native American resistance and movements have not collapsed; rather they continue into the twentieth century, allowing for their persistence. Therefore the earlier Spanish narratives of what Wilcox calls a "mythology of conquest" have been challenged as interdisciplinary models are applied. (Wilcox 2009:146).

Wilcox argues that historians and anthropologists have contributed, whether consciously or unconsciously, to the erasure of indigenous peoples' history. If history is treated this way, it only contributes to as Wolf notes (Wilcox 2009) "the tacit supposition that 
people like these are without history (and) amounts to the erasure of 500 years of construction. . .anthropology all too frequently operates with its mythology of pristine primitive" (2009:13).

Today, laws have revolutionized the way archaeology has been conducted. For example, the Native American Graves Protection and Repatriation Act (NAGPRA) has provided the right to protection of Native American sites, human remains and associated artifacts (only for federally recognized tribes), as well as affording a process of collaborative archaeology that includes historical indigenous history. Protecting Native American heritage, which had been often ignored by academia in the past, has taken on a new dynamic by directly involving and empowering tribal communities in all stages of archaeological inquiry (Leventhal et al 1994, Cambra et al 1996). Today we have the capacity to revisit these narratives and make the effort to contribute to writing indigenous stories that incorporate their own perspectives (Leventhal et al 2011).

\section{Archaeologies of Persistence}

Anthropology has helped to create a myth of extinction which has negatively affected various native groups (see Leventhal et al 1994; Field with the Muwekma Ohlone Tribe 2003; Field et al 2013). The persistence approach to archaeology, however, can help right the wrongs that resulted from the myth of extinction by focusing on the ways that cultural traditions persisted during and after colonialism (Panich 2013:106). One such archaeologist who focuses on persistence is Lee M. Panich. Panich's approach states that there are three contemporary or recent "primary areas of current archaeological theory - identity, practice, 
and context - that are particularly well suited to archaeological studies of indigenous persistence" (2013:06).

Using the persistence approach to identity allows archaeologists to get away from acculturation models and focus on the "fluidity of identity in colonial settings" (Panich 2013:107). Panich claims that identity is actually a social construct that "can be transmitted across generations despite far-reaching changes in other aspects of life" (2013:107), and he asserts that native identities were constructed "both before and after the onset of colonialism" (2013:108).

Panich further claims that "the application of practice theory in archaeology allows us to examine how the social world is constructed" (2013:107). He explains that this approach of practice theory can be applied to archaeology of colonialism where it can be utilized to understand how change developed over both short- and long-term time periods. Change, he asserts, was not only a result of contact, but also came from "within native societies that drew on existing beliefs and practices to actively negotiate the colonial period" (Panich 2013:109). Context, according to Panich, is useful to archaeologists because it reframes terminal narratives and allows indigenous lives to be looked at not only within the context of colonialism, but also as being part of complex and developed societies that "do not necessarily define themselves as products of colonialism" (Panich 2013:110). Archaeologists then have a unique position to illustrate the "dynamic nature of culture and identity and to thus contextualize the disjunctures of colonialism within the long-term history of indigenous groups and to understand their significance for native communities today" (Panich 2013:107). This approach provides a way to connect past histories to contemporary histories. 
One of the questions Wilcox raises to support his argument is "How do you explain the persistence of the indigenous people?" (2009:18). Such a basic question sets a landscape for viewing the Native American history that persisted parallel to that of their European colonizers. The word persistence also means that native peoples had to endure and develop survival strategies in colonial times (Panich 2013). This new ideological world can be seen in the archaeological records or primary accounts pattern of way from pueblos (Wilcox 2009) and places of refuge from the mission system (Schneider 1995).

The way we understand and approach archaeology should move away from narratives that blind us from the native perspective of history. Panich (2013) argues that archaeology should focus on changing the two narratives that have been popular in North America: disease and cultural extinction. He suggests taking into account "(d)ifferent multiple scales of analysis- daily practices as well long-term processes" (Panich 2013:105). The day to day practices of labor show persistence of the natives as "hundreds of Native American communities have persisted into the present despite repeated popular and academic claims of imminent demise" (Panich 2013:105). Such evidence has remained outside the historical account because scholars have often focused mainly on those terminal narratives about Native people, which are still present (Panich 2013:105; Leventhal et al 1994).

\section{Agency}

In terms of reactions of the natives, Lightfoot (2005) emphasizes indigenous agency and notes that many indigenous people consciously decided to move into missions for various reasons, such as forging alliances, seeking religion, or wanting a change in social status. Lightfoot's research demonstrates that native people did have the choice to resist, 
which ties in with James C. Scott's (1985) idea of resistance from Weapons of the Weak. Scott states that under certain conditions, peasants (and by extension others living under situations of extreme hegemonic control) had strategies ranging from foot dragging to sabotage for resisting these controls (1985:29).

Scott poses the question, "Can individual acts such as theft or the murder of livestock be considered resistance even though they involve no collective action and do not openly challenge the basic structure of property and domination?" (1985:300). Such a question profoundly changes the focus of the actions committed by individuals toward Spanish entities and redefines the very nature of resistance.

Scott's (1985) work indeed reveals that resistance can take many forms. One act of passive resistance can be dragging one's feet to slow a process. Although this may seem inconsequential, such resistance on a daily basis could affect production, causing friction between laborers and elites. Scott (1985) also discusses rebellions that can result in some short-term or limited changes; however even with these changes, people at the bottom remain more or less in the same situation, finding themselves resisting again as the colonial system counterattacks in a stronger fashion than the previous one. He further states that class resistance includes any counterhegemonic act by a member or members of the subordinate class (Scott 1985). 


\section{Summary Statements}

Through these approaches to understanding contact between indigenous peoples and European colonizers—and the broader context of global capitalist expansionanthropologists have developed a multidisciplinary approach to holistically formulated research. This signals a shift from a unidirectional lens to a more complex interaction resulting from the imposition of the capitalist mode of production. We can apply political economy and world systems approaches, labor theory, indigenous archaeological perspectives, archaeologies of persistence, and agency deployed by subjugated peoples who actively resisted domination to develop a more sophisticated understanding of Native American struggles in the Americas. Using these theoretical frameworks, let us now turn our focus to a re-examination of indigenous histories in the Bay Area. 


\section{CHAPTER 4: RESEARCH DESIGN}

This project focuses on the cases of three San Francisco California Bay Area Natives and their response and resistance to the Spanish colonial system: Pomponio, a Coast Miwok Indian who joined Mission Dolores in 1803, was later an alcalde at Mission San Rafael, and became liminal for five years until his execution by firing squad in 1824; Estanislao, a Lakisamme Indian who became an alcalde of Mission San José in 1829 and later led a major revolt; and Yozcolo, a Lakisamme Indian who was an alcalde at Mission Santa Clara de Asis and who was instrumental in resisting the colonial system, but who was eventually murdered by colonists in 1839 .

In all three cases the evidence shows Native American response and resistance to Spanish colonization and specifically to the imposed mission system. Each of these men led groups of affected Native people, which fit into the larger sphere of resistance to the colonial system in other parts of California and the Americas. Applying a historical framework and an anthropological approach to consider dynamics of labor and identity in this context, this research project provides a vital multi-vocality to mission history by avoiding terminal narratives and marginality of Native Americans in this era. Using primary sources, such as first-hand accounts from Spanish soldiers and priests, correspondences, and baptismal and death records, and also secondary sources from scholarly works on this time period, this project investigates the social impact of these leaders and their respective decisions to overtly resist against a powerful colonial system. The following questions are addressed in this project: 
- In what ways may Native Americans resistance leaders be considered criminals versus unsung heroes for their efforts to liberate their people from mission life?

- How does a reexamination of primary documents and historical records provide alternative perspectives about the Native American response and adaptive strategies in relation to the arrival and establishment of presidios, missions, and pueblos within their aboriginal homelands?

- How does the history of Alta California mission rebellions relate more broadly to the course of Spanish/Mexican colonial history? What exactly are the social, political, and identity implications of the conquest of Native American tribal communities?

- Employing theoretical methodologies forwarded by Wilcox (2009) in his study within the pueblo region of the American Southwest, how can we link the history of resistance and continued persistence of those Native Americans aboriginal to the greater San Francisco Bay Area to modern tribal groups?

\section{Background Information of the Three Resistance Leaders}

\section{Pomponio: 1821-1824}

Pomponio, whose native name was Supugeyun, was baptized in the San Francisco Mission Dolores (Early California Population Project 2006). The date of the baptismal record has January 2, 1803 (Brown 1975). His record shows that when he entered the mission he was 4 years old. Next to his name, a note reads "havido en la gentibilida," meaning he was in heathen land. His father's neophyte name was Francisco from Mission Dolores. His 
godfather is listed as Luis Arguiello, a military soldier that later become governor of Alta California (Early California Population Project 2006).

Pomponio "was such a leader, who after baptism fled the forced confinement and servitude of the missions. He then joined other neophytes who also escaped, but who were no longer welcome among their own people" (Kurt 2002:74). Pomponio became an alcalde of Mission San Rafael, he fought against the colonial system and "as well against Indians who succumbed to the Spanish: presumably Ohlones or Costanoans, since he was probably a Coast Miwok" (Holterman 1970:19). Pomponio also became a subject of "rumors, folktales, and gossip of his whereabouts, his next target, and his last or next crime" (Sandos 2004:

170). There are various stories of Pomponio's resistance to the colonial system, and therefore those writings made his image full of mystery.

Holterman (1970) states that upon being captured in San Francisco, Pomponio cut off his heel in order to free himself from foot chains, but Bancroft (1888) claims that it was his partner, Gonzalo, who had cut off his own heel. This demonstrates an act of courage, or perhaps desperation, which Native Americans sometimes resorted to rather than remaining in the hands of the colonial authorities. Although the missions were facing other problems such as economic hardship at the time, Pomponio seemed to be a bigger threat to the colonial system. Perhaps this was because he was a ringleader and therefore a threat; thus the colonists felt the need to capture and control him. Browns states that Father Viader, a priest from Mission Santa Clara, claimed that Pomponio "and his band were called the Insurgents" (Brown 1975: 16). Brown further states that “in Latin America, in the early 1820's, the term must have been used seriously and not in fun: Monterey had been pillaged and burnt by 
invading 'Insurgents' in 1818, shortly before the outlaw's career presumably began" (Brown 1975:16). Therefore the use of such language reveals what a threat Pomponio and his fighters were to the mission.

However violent events in the form of expeditions were in full force at this time, inflicting structural violence to control the indigenous people to make them stop resisting and raiding. Amador's recollection provides a description of an expedition with Captain Arguello to placate the Indians.

On one occasion, I was in an expedition with Captain Luis A. Argüello. I do not remember the year; I do know that it took place before Argüello became governor, so it must have been before 1823. We entered through Napa to reach Santa Rosa. There, at the stream, 200 Indians approached us. We were on this side of the small stream; they attacked us with arrows (Mora-Torres 2005:69).

Amador finishes this recollection by saying that the purpose of this military mission was to stop the Indians from fighting against the Spanish authorities:

On this part of the journey we managed to capture two Indian captains for whom Argüello ordered 200 lashes each so that they would never again take up arms. This expedition had as its objective to pacify all Indians so that when the troops entered their territories would not resist, or use their weapons against our soldiers (Mora-Torres 2005:69).

Pomponio was “in Lieutenant Martinez' jail for what we can assume to have the first and last time by October, 1823... sentenced by council of war" (Brown 1975:15). Pomponio was executed February 6, 1824, as records from the Carmel Mission register show, after his confession and taking of communion (Brown 1975:16). 


\section{Estanislao: 1829}

Cucunichi, an Indian Lakisamme Yokut of twenty-eight years old, was baptized with the Spanish name of Estanislao by Fray Buenaventura Fortuny (Early California Population Project 2006). According to Sandos, "Estanislao seems to have been born of high status among the Lakisamme Yokuts around 1800, and was brought to the mission for baptism at an early age" (Sandos 2004:170). This ceremonial event happened on September 24, 1821, at Mission San José. During this time his wife, whose name was Youatae, was also baptized (Early California Population Project 2006). Estanislao worked as a mule tamer and then became an alcalde at Mission San José. One day, while having a pass to his village located in the San Joaquin Valley, he sent a message back "to inform Padre Duran that Estanislao and his people declared themselves in rebellion" (Sandos 2004: 171). This happened around 1828 or 1829.

The rebellion of Estanislao may have had to do with the growing demands of labor, or perhaps he saw that his tribal members needed his support. However it may also have had to do with the politics between the government and the church, affecting the living conditions at the mission. Whatever the case, something triggered Estanislao's decision to take up arms and join his tribe and other Indian leaders in resisting Spanish incursions within their territories. During the rebellion, Estanislao acquired fame for being a fierce warrior and was joined by other runaway neophytes from various missions as well as unconverted Native people. 
The Estanislao rebellion highlighted the tensions of the missionized San Francisco

Bay Area indigenous peoples under the colonial system. Bojorges chronicled the expeditions against Estanislao's rancheria who had built a fortress on the river of the same name:

We left around the month of April 1827 from the Presidio of San Francisco with a number of 40 soldiers sent by the Commander Pablo Pacheco, in the direction the Stanislaus River, with the motive that the chieftain Estanislao had refused obedience to the Fathers of the Mission of San José Fr. Narciso Durán and Fr. Buenaventura ...with the reason that likewise another chieftain had seduced many Indians of San José, Santa Clara, and San Juan Bautista in a considerable number. After 5 days traveling we reached the aforementioned river, where we found the Indians... which they made a strong defense (Bojorges 1877:14).

Estanislao was not the only leader who was involved in this battle, since Bojorges (1877) mentions that several other leaders (capitans) had gathered other Indians from the San José, Santa Clara, and San Juan Bautista missions. The physical setup that Estanislao and other resistance leaders had in place only allowed for two entrances, thus allowing them to easily detect intruders. At the same time, they had set a barrier so that the enemy could not reach Estanislao's encampment. Bojorges gives the following account, which shows that Estanislao was familiar with the Spanish language:

Then the soldier Pacheco sent an interpreter that had accompanied us from Mission San José to tell him to hand over the Christians Indians he had there. Estanislao answered that he would not hand over anybody and that if they were men enough to come take them out themselves, saying many bad words and insults in Spanish, and shooting a large amount of arrows at the troops. And the troops withdrew firing bullets because they feared that (Estanislao) might cut off their exit from the woods. As they went to camp a short distance outside the forest, a soldier who went to reconnoiter the Indian encampment, received an arrow shot from afar in which the feather wounded his face (Bojorges 1877:15-16).

In this specific event Estanislao and his warriors defeated the Cabo Pacheco expedition, which as can be imagined, gave them a sense of triumph over their enemies. 
However, the expeditions kept coming. For the next expedition the Alferez (captain) Don José Sanchez took more military forces including artillery from San Francisco and Monterey, as well as a group from San José. Bojorges' account of that expedition shows that once again, they failed to defeat or capture Estanislao, who seemed to have in this case outsmarted them:

After 4 days of travel, (the company) sighted the camp of the Indian Estanislao, thinking to quickly enter the forest which I have already referred: they soon began to fire upon them with the cannon and the carbines, and the Indians began defend themselves with bows and arrows. Soon the Indians shot four of the settler auxiliaries, mortally wounding one (Bojorges 1877:17-18).

Bojorge's narrative of the ensuing revolt provides information about the way Estanislao left the scene of the battle: "Estanislao came out with many Indians and shot at the soldiers with a rifle of one of their comrades, tossing his hat up in the air, shouting in Spanish very rude insults, and yelling the name of some of the soldiers" (Bojorges 1877:21). The manuscript narrative of Osio, which also describes the revolt of Estanislao, claims that "because of the governor's poor administrative practice...it began to be noticed at various missions that the alcaldes were behaving insolently and were entertaining subversive threats. The territorial leader was informed of all this activity" (Beebe 1996: 88-89). Estanislao left with his tribe and Father Narciso Duran sent expeditions to capture the runaway neophytes. However, Estanislao was ready for the Spanish authorities and ultimately won the first two battles against Cabo Pacheco and Don José Sanchez and left the scene victorious (Bojorges 1877).

After the defeat of the Spanish expeditions by Estanislao's Lakisamme warriors, "in retaliation, in May 1829 the California government sent twenty-two-year-old Lieutenant 
Mariano G. Vallejo to attack Estanislao" (Sandos 2004: 171). This was a powerful response from the colonists against the natives, in which they used in their campaign "107 Californio soldiers, 50 auxiliaries, 1 cannon, and more musket cartridges, 3,550 that had ever before been assembled for a military campaign in California" (Sandos 2004: 171). However, Vallejo did not capture Estanislao, as he had already made his escape. Later at their arrival to Mission San José, they realized that Estanislao had the protection of Father Duran, who had been given pardon by orders of the governor. Estanislao returned to Mission San José, perhaps seeking protection or showing willingness to negotiate with the Spanish authorities, since at this point his options had been reduced due to Vallejo's expedition causing devastation to his people. After his surrender, Estanislao was left to remain at the mission. Although the exact reason for this is not known, it can be speculated that perhaps his agency (status as an alcalde) provided him with that option and protection.

Estanislao later died at Mission San José. As José Maria Amador states: "I wish to note here that when the small pox epidemic arrived here in 1839 , the captain of that Rancheria, who was called Estanislao, died infested with worms, along with many of his companions at Mission San José" (Mora-Torres 2005:69). This disdainful account of Estanislao's death perhaps reflects frustration at never having been able to defeat him. According to the death record of Estanislao, he died on August 12, 1838. Three days after Estanislao's death, José de Jesus Vallejo requested (letter to the Alcalde of San José, August 15,1838 ) help because of an Indian uprising and asks to send soldiers to mission San José. This Indian uprising perhaps can be tied to the death of their former leader Estanislao. 
While Estanislao was a leader who inspired his people to resist, his death did not end the movement. Cook states that after secularization in 1834, Indians resorted to other methods of resistance:

By the time of secularization, the natives had begun to pass actually to the offensive. One reads in every general history of the times a great deal about the activity of the valley Indians, and to a lesser extent of those north of the Bay, in raiding and stealing domestic livestock, in particular cattle and horses. This phenomenon is one of great biological and cultural significance. It is mentioned here, however, only as it bears on offensive warfare (Cook 1976: 230).

Francisco Palomares' accounts are about expeditions to the Sierra in search of indigenous bands who led raids on the ranchos around Pueblo de San José. Since Palomares does not provide dates for these expeditions, it can be speculated that they occurred before the 1839 Yozcolo revolt, and the following expeditions likely took place before secularization, during, or just after secularization. As Cook above states that the natives turned on the offensive to put pressure on the ranchos as a new survival strategy. This correlates with a description by Palomares of expeditions against such raids:

General Figueroa, seeing that the savage Indians of the Sierra Nevada were making frequent incursions against the ranchos of this jurisdiction of San José and others, ordered the resident Sebastian Peralta from the already mentioned place, to round up people and go after and attack them in their own Rancherias. Peralta easily got together a force of seventeen men from among the veteran Indian campaigners, who were ever ready to fight the enemies of their property, and this without letup, until their extermination; among them went the author of these recollections (Temple II 1955:22-23).

The dynamic between California Indians and the Spanish colonists changed drastically at this time. The natives had the upper hand as they adapted new survival strategies and with the utilization of the horse. As a result they had become more dangerous to the rancho owners. 
According to Holterman (1970) Yozcolo and others were still in the field raiding. The annals mention various actions. For example, a neophyte Nifador was murdered by “insurgents around Livermore in 1836. Two ranches near San Juan Bautista were ravaged in July of 1838, and in September and October two punitive expeditions struck out at the raiders. Yet the raid continued on into 1839" (Holterman 1970:22).

Milliken and Shoup state that "desertion by Christian Indian and raiding by rebel Christian and San Joaquin tribal people were only two of the reasons why Mission Santa Clara declined during the 1830s" (1999:104). Also at this time, the rise of a new form of ruling class emerged. Family ties with the Spanish cultural rite called Compadrazgo "best labeled the Californio ranchero oligarchy" (Shoup and Milliken 1999:104). The result of this elite class was formed by decades of migration from Mexico, Spain, and Anglos from the east on some occasions. The rancheros became powerful and began to acquire land. "Men like Mariano G. Vallejo, José de Jesus Vallejo, José Castro, and Juan Bautista Alvarado, led the fight to expropriate mission property and its Indian labor force so that they, along with their allies and relatives, could benefit" (Shoup and Milliken 1999:104).

Secularization, which was a law to redistribute the land from the 21 California missions, happened at different times during the 1830s for each Mission. The law" had originally been the intent of the missions to "civilize" the Indians and bring them into the mainstream of Spanish/Mexican live, the return their land to them to farm for themselves (Shoup and Milliken 1999:106-107).

However, the law that was introduced was not always what the officials applied to the secularization process. The demands of conservatives and liberals were different: the conservatives wanted to delay the secularization processes, whereas the liberals wanted the processes to be quick. Nevertheless, the "mid-1833 during the governorship of José 
Figueroa, when the Mexican congress passed a sweeping law mandating the beginning of actual secularization" (Shoup and Milliken 1999: 107). These processes, according to Shoup and Milliken (1999), were the first to remove the Spanish born Catholic fathers and replace them with Mexican-born secular priests. One other goal of this law was to pass the power to secular administrators. Rarely, the Indians benefited of the land grants "even though regulations called for them to receive land, tools, animals, and seed" (Shoup and Milliken 1999:107). After the rebellion of Estanislao in 1829, more forthright resistance began since as described by Shoup and Milliken, the secularization process was taking the lands from the mission and not distributing to the Indians.

\section{Yozcolo: Late 1820s-1839}

Yozcolo, from Mission Santa Clara, is another leader who may have joined Estanislao in his revolt. Yozcolo is described as "the main guerrilla chief still free, and probably one who had been operating the longest" (Holterman 1970: 2) against the colonial system. He was a Laquisamne [Lakisamme] neophyte of Mission Santa Clara, where he became an alcalde when he was 21 years old (Holterman 1970). According to some accounts, "Yozcolo is said to have raided the mission stores with the help of 500 subordinates, making off not only with horses and cattle but also 200 girls from the female dormitory" (Holterman 1970:21). The last act of resistance in which Yozcolo participated was at the ranch Encino Coposo, which the soldier de Cuera Francisco Palomares depicts in his narrative of Yozcolo's last moments fighting.

The commander then ordered that all the war Indians from the mission be gathered, up to the number one hundred, and told them to be ready the following day, (this happened the same night that Yoscolo attacked, about six hours later); that they would 
go against Yozcolo with five of his group that had surprised the residents of the ranch Encino Coposo (Weary Bushy Oak) and killed two of them. The Indians promised to be ready. The next day, early in the morning, commander Peña left the mission with its one hundred Indians and 4 or 5 soldiers of the escort, and in as much as the number of people and the land allowed it, he left violently in pursuit of the gentiles, whom they reached in the mountains, some leagues from where they had committed the murders (Palomares 1877:27-28).

Palomares' account of pursuing the leader Yozcolo shows how much effort was given in taking on the chief who had acquired those methods of resistance that Cook (1976) states began early in the entradas and as the colonists began to populate the region. Yozcolo fought until his death, even though he was outnumbered

A common method used by the colonists was to employ other neophytes as military auxiliaries, in this case from Mission Santa Clara, to warn the other neophytes. In this case, after his death, the colonists cut off Yozcolo's head to make an example out of him, and to terrorize the neophyte and native populations to make them understand who was in power (Palomares 1877). The murdering of the leader Yozcolo by the Spanish elites may not have changed the attitudes of the natives, however, Palomares comments that the theft of horses became less frequent.

Even after the death of Yozcolo, the resistance against the colonists did not end. "Resistance continued past 1836, directed against the secular Mexican and later American societies that replaced it...Indian resistance outlasted the missions because some Indians continued to oppose all attempts at domination" (Sandos 2004: 173). Cooks states that "by 1845 the valley Indians had made inland invasions very costly and dangerous, but, more important, they had also actually begun to drive in the Spanish frontier" (Cook 1976:231). California became part of the United States after several battles with the Californios mainly 
in the south of California. In "July 1846 when the American Commodore (John Drake) Sloat took possession of Monterey and the rest of California in the name of his government and because Mexico and the United States were in a state of War" (Mora-Torres 2005:187). The United States saw California and other Mexican territory as part of its 'Manifest Destiny' expansionist policies during the 19th century (Shoup and Milliken 1999:125). American expansion led to increased resistance and battles, including the Battle of the Mustard Stalks near Mission Santa Clara on January 2, 1847 (Shoup and Milliken 1999:125). This event was another turning point in favor of California Indian resistance to colonization.

Earlier works on California Indians from earlier scholars are based on how the Indians reacted to the Spanish/Mexican Periods. Some scholars, like Hubert Howe Bancroft, treat research simplistically, without going into depth about the particular event or account, especially when it came to Native Americans. Bancroft provides a summary of primary documents, which he collected from throughout the State of California through correspondence and ethnohistory. Although the indigenous perspective of the colonization or occupation of their lands is lacking, Bancroft's documents provide a clear picture of the perspective of European-Americans toward the Native peoples of California during this era.

Hubert H. Bancroft and Father Zephyring Engelhardt "both were careful scholars who, after collecting and scrutinizing vast amounts of material, wrote detailed accounts that remain basic...in both there was an underlying view that emphasized the romance of the missions and ranchos of the Spanish and Mexican Periods" (Cook 1943: ix). When writing in regards to the Native American leaders that resisted the colonial system-including Pomponio, Estanislao, and Yozcolo-Bancroft portrays them as dangerous criminals or 
outlaws. Bancroft mentions, for example, that Pomponio "for several years had been notorious as an outlaw and criminal" (Bancroft 1885:537). This treatment is from a unidirectional perspective of history instead of a multidimensional perspective, and does not include an analysis of the response and resistance of California Natives. During the late 19th century, many people uncritically received information on this time period through Bancroft's works. Further, years later, other important publications on Native Americans, such as the Handbook of the California Indians by Alfred L. Kroeber in 1925, did nothing to highlight important leaders such as $\square$ Pomponio, Yozcolo, and $\square$ Estanislao. In fact, Kroeber’s monumental study makes no mention of their names.

Jack Holterman (1970) wrote about Yozcolo in 1970 in $\square$ the journal The Indian Historian. As a revisionist, he took another approach to research the history of San Francisco Bay Area Native Americans. His main subject was the leader $\square$ Yozcolo, as well as other Native leaders from the San Francisco Bay Area missions. Instead of subjectively portraying the natives as villains, Holterman $\square$ wrote about important Native American figures such as $\square$ Estanislao and he described his revolt in 1829 .

The work of Alan K. $\square$ Brown, $\square$ Pomponio's $\square$ World, provides a similar view of early California, discussing those men "who had to watch hundreds of their charges dying at a time from so called childhood disease which no one knew how to cure, could be no more than human in some of their reactions" (1975:3). Brown states that "too many recent textbooks avoid the problem of mission history by concentrating upon extremely minor and unimportant early political events" (1975:3). Brown further compares the works of Cook and Reverend Maynard Geiger, stating that Cook makes "devastatingly negative observations," 
whereas “Geiger's recent book on Mission Santa Barbara provides a careful and fare more sympathetic treatment of a single, well recorded and apparently well administered mission settlement" (1975:3). Unlike Bancroft's previous research, which focused on a macro lens of history, Brown investigates particular individuals who, despite being outlaws in the eyes of the colonists, arose to become important leaders. He states that detailed research is needed to understand Pomponio's background by looking at other causes that could have had an impact on Pomponio's livelihood and his response. Brown (1975) is objective in his approach to documenting what he refers to as "Pomponio's world."

Another scholar, biologist Sherburne F. Cook, wrote the book, $\square$ The Conflict Between the California Indian and White Civilization $\square$ (1976), in which he analyzes California Native American demographics to investigate population decline due to the influences of Spanish and Anglo-American cultures. Cook includes human ecology to denote all the relations of a biological group with its physical and social surroundings (1976:1).

Cook states that his research is between two civilizations "one old and static and the other new and dynamic" (1976:1). He uses historical primary documents and experimental methods to examine events that occurred in the past. Demographics are the quantifiable explanations of a given population, which examine a population at a specific point in time. Cook states "the weaker established race gave way with little opposition to the stronger invading race" (1943:1). He applied historical data from Bancroft Library and works of anthropologist A. L Kroeber. However, it is interesting to note that the leaders/alcaldes (Pomponio, Estanislao, Yozcolo) are only mentioned in passing. Cook's lack of understanding of the complex California Natives makes his study partly useful, as today the 
research conducted by contemporary scholars show a thriving, complex society that existed before European contact.

Randall Milliken's published doctoral dissertation from 1995, A Time of Little Choice; The Disintegration of Tribal Culture in the San Francisco Bay Area, includes translations of twenty-four documents written by members of the Spanish military and the ecclesiastical entities that settled in the San Francisco Bay Area. Milliken, an anthropologist/archaeologist, brings a new perspective that focuses on the San Francisco California natives by analyzing mission register data. He built upon the previous work of Cook, but asserts that indigenous peoples of the missions made many a "decision during a time when changes in their world seemed to leave them little or no choice to do otherwise" (Milliken 1995: xiv).

Milliken states that social organization, work conditions, hygiene and the increase in populations created a food shortage. He claims that while tribal villages continued to resist the Spanish, for a vast portion of the natives, the mission $\square$ was the only choice. He notes that the Spanish were not as interested in taking land and resources as they were in totally restructuring the lives of indigenous peoples (Milliken 1995:225). However, Milliken's focus does not include important events that happened after 1810, which have much to do with the California Indians' reactions to the colonial system once in place in California. He notes mostly the rare overt resistance at the missions, although a group of Mission Santa Cruz men did poison a missionary in 1812, and finds a more "common expression of protest was a listless attitude and a lack of cooperation toward work activities" (Milliken 1995:225). 
Many earlier scholars of the early history of California, such as Bancroft and Kroeber, have either romanticized or overlooked important figures and events in the native history of California. Other scholars (e.g. Castillo) who do mention resistance leaders fail to go into depth on their social impact. Brown and Holterman address the impact of these leaders, yet their publications remain only in the hands of a few, since their work was published in somewhat obscure journals. Cook also fails to add the complex understanding of the Native Americans, however, his work does suggest the stresses of the introduction of colonial systems into California. Milliken's work is limited in its time frame, as it focuses mostly on the time from 1769 to 1810 . This present study addresses these major gaps in the study of mission history by focusing on the social and political impact of several indigenous resistance leaders in Alta California.

\section{Review and Translation of Primary and Secondary Historical Sources}

The historical accounts used in this study are from primary and secondary sources. Historical information was gathered through a close reading and analysis of primary (both in English and Spanish) and secondary sources. As a native speaker of the Spanish language, I translated and transcribed textual information from personal correspondences from secular, military, private, and ecclesiastical institutions, court proceedings, conquest narratives, and other ethnohistorical accounts from Californios, all of which contain valuable information on different perspectives of colonial life. Primary documents were collected from the Bancroft Library in Berkeley, History San José, and the California Room at San José State University Library and were translated from Spanish into English. These documents are placed into a 
historical context with the aid of secondary sources from books and articles written by scholars on the history of the Spanish Colonies.

\section{Translation Procedure}

I had enrolled in the Seminar in Hispanic Civilization and Culture course to aid my methods of collecting data and the translation of primary documents in order to find nuances that could provide an alternative perspective to the resistance of Native Americans of the San Francisco Bay Area from 1769 to 1846 . Employing as a model the technique used by the Cibola Project from the University of Berkeley, the first procedure was to complete a transcription of the original primary document, leaving the paleographic writing in place. Beginning from the first line, every fifth line is marked with a numeral, with a five by the fifth line, a ten by the tenth line, and so on. This process of numbering every fifth line is useful to guide the reader if needed to identify a particular line on the original document.

The second procedure was to make a translation into modern Spanish in order to have a copy that is easily understandable to the contemporary Spanish speaking public. This process involved correcting any old and antiquated spelling and writing out abbreviations. In writing out abbreviations, the letters that were added were written in italics to inform the reader that they had been added to the transcription; for example, pa. becomes para.

The third procedure was the step in which the translation to English took place. This was a straightforward translation in which the document was translated as closely as possible without straying from the original meaning. Fourth, I used a historical framework to contextualize where the document was written and where the original or copy could be found. 
Using historical accounts is a method that is nondestructive in nature and can be replicable, unlike most archaeological research. Using this methodology of collecting primary and secondary sources of history and including an ethnohistory account brings a new perspective on the colonial systems that impacted San Francisco Native Americans and contributed to their reactions.

In addition to the translation of primary documents, this project drew upon baptismal and death records of the study subjects from the database of the Early California Population Project online through the Huntington Library. These methods that were used to gain an understanding of the California Natives are not unique to this project, since several of the scholars referenced have previously translated documents to write about California Native American history. However, employing a multi-theoretical approach has provided a more holistic view to the life of the California Native Americans under colonial regimes.

This project also focuses on the primary sources from the periods during which Pomponio, Estanislao, and Yozcolo were active as Native American leaders. It highlights their survival strategies in times of stressful social or political processes, such as the destruction of their culture. Perhaps with the fear of their own extermination, these men who had once been alcaldes - armed themselves against an oppressive colonial system. In the following Discussion chapter, I will examine the results of the translations and how they help us understand the stresses that caused indigenous resistance and response. The story of these three leaders focuses on how they responded to forced labor practices, the treatment of Native Americans by the missionaries, land occupation, displacement, and the Spanish attempts at extermination of their lifestyle. This narrative provides a history counter to that 
written by those who hold more advantage in the dominant society, and as such exposes the struggle of the California Natives and critical aspects of their mission experiences. 


\section{CHAPTER 5: RESULTS AND DISCUSSION}

\section{Introduction}

The history of Alta California, as documented through primary and secondary sources from 1769 to 1846, illustrates a multidimensional history of indigenous response, resistance, and persistence as colonists moved in and began to settle on New Spain claimed lands. The focus of this study was to include processes that disrupted, transformed, and molded the social and economic lives of the indigenous peoples of Alta California. Revisiting these historical narratives allows these stories to be reconsidered and rewritten from the indigenous perspective. Many scholars (Castro 1996; Leventhal et al. 2011; Panich 2013; Wilcox 2009) have taken this approach. The history of the Native American people has begun to be rewritten by these scholars, some of whom are indigenous themselves. Using an anthropological and historical framework for archaeologies of persistence, resistance, and social agency, the fragmented history of the indigenous peoples' past can be better connected and understood.

A large number of scholars have contributed to the understanding of the history of California Natives. Many of them (e.g., Bancroft 1888; Brown 1976) have translated primary documents from the colonists' perspectives, detailing experiences with their interaction with indigenous people. However, scholars can agree that the colonists' treatment of the indigenous was not different from what they had already done in the rest of the Americas (Mexico, the Caribbean, Central America, and South America). This chapter presents a discussion of my analysis using a multi-theoretical and anthropological/archaeological approach with a historical framework to introduce an 
indigenous perspective, generating a new alternative perspective to California history from 1769 to 1846 . Ethnohistory contributes to the emic perspective of the colonial period from the view of Californios and their role in expeditions. Their experiences focus on the response, resistance, and persistence to illustrate a different history that shows identity fluidity.

During the expeditions from 1769 to 1776 , three responses of the natives were observed: one that showed native flight, another in which the natives welcomed the colonists as distinguished guests, and the third in which native groups showed overt resistance to colonizing forces (Brown and Stranger 1969; Milliken 1995). In the flight scenario, the natives fled their villages when they became aware that Spanish explorers were approaching on horseback (Mora-Torres 2005). At other times, indigenous people of the area viewed the foreigners as distinguished guests, and welcomed them to their villages with gifts or food (Galvin 1971). The third reaction was to resist the colonial system by escaping from the missions or attacking the colonists who came to their villages (Cook 1976).

The written accounts of Franciscans Palou, Crespi, and Santa Maria demonstrate indigenous rules of social interactions, their customs and their social agency. From 1776 to 1796, the colonists began to settle the San Francisco Bay Area and the surrounding valleys, founding missions, presidios, and a pueblo. As the colonists began settling the indigenous land, the natives began to see the destruction and disruption of their spiritual, economic, and social sphere.

During the period from 1796 to 1810 , further stresses began to affect the natives of the area. Spanish authorities continued with the acquisition of native land and the recruitment 
of neophytes for the missions. Other stresses that contributed to the reactions of the indigenous peoples came from governmental and ecclesiastical disagreements having to do with the treatment of neophytes. Furthermore, the influence of global political changes as peripheral colonies became independent from the core transformed the social and physical environment of Spanish colonies. Under these stresses, the California Natives began to react to the encroaching power of the colonists.

From 1810 to 1834 , there was a rise of Indian leaders who fled from the mission: Pomponio in 1821, Estanislao in 1829, and Yozcolo, which Holterman (1970) states was either in 1829 or 1839 (Bojorges 1877; Brown 1975; Sandos 2004). There were signs of resistance in other parts of California as well, such as the Chumash people's uprising in Mission Santa Barbara. Indigenous people continued to show agency well after California was acquired by the United States in 1846-48. New translations of letters and narratives dating from 1769 to 1839 clarify the dynamics of political economy, labor organization, native agency, and the indigenous perspective during this era.

\section{Political Economy}

The occupation of Alta California was accelerated by governmental, ecclesiastical, and private goals. The government had at least one role: to secure and protect presidios, missions, and pueblos with their heavy artillery and soldiers. The major ecclesiastical aim was to convert the natives to Christianity, bringing them into the mission and using native land as part of the production model. The private/secular interests saw it as a chance to improve their own personal economic positions. 
When considering or introducing the reactions and responses of the California natives, the goals of the colonists provide a historical framework that is not the usual lens, but an ethnohistorical account that includes the indigenous role in the overall history. Their role is not unidirectional but instead can be interpreted as multidimensional. Previously unconsidered or unknown aspects of native roles in the economy show the stresses that the natives had to endure under this system.

Political economy as a method has been used to understand human activity and the influence of external forces. This method, when applied to the economic, political, and ideological motives of the colonists, portrays a more holistic history of Alta California. Political economy takes into account the global influence of capitalism, which, even more so than colonialism, was the driving force at work. This was because the Spanish Empire needed indigenous labor in order to keep up production.

\section{Labor Theory}

Silliman (2001) claims that labor changed the lives of the natives from outside and inside of the mission. However the relationships between both the colonists and natives were connected and dependent upon one another, something that is shown in Galindo's (Shoup and Milliken 1999) description of Mission Santa Clara's dependency on indigenous labor to produce a surplus. This interdependence can be seen when examining the three goals of the colonists (after converting the heathens to Catholicism): to use the land, create a labor force, and to form a control system to enforce the colonial system.

When conceptualizing labor with a world system and interregional approach, this new data support Silliman's claim. The new Spanish labor activities were foreign to the natives 
prior to contact, and introducing them did not necessarily mean acceptance; therefore strict controls were enforced. However, the Spanish labor model did change the social and economic systems of subsistence that the natives of Alta California were accustomed to prior to missionization. Cook states:

His reaction to labor itself, in the abstract, must be considered, since mental or bodily exertion of the type demanded by white civilization was completely new to him. It constituted an environmental factor, of the nonmaterial type, with which he had never come in contact and which therefore required an emotional and intellectual readjustment or adaptation very difficult for him to make (1976: 95).

At the presidios, food for the military was produced by Native American labor. The soldiers of the presidios were dependent on the presidial stores that were supplied by two sources: "manufacture goods sent from Mexico and agricultural products - flour, corn, beans, as well as soap, shoes, and blankets - from missions" (Pubols 2010:33). According Louis Pubols, "in theory, California was a colonial dependent of Spain; the soldiers lived on fixed salaries, payable in credit at the presidial stores. This store was to receive goods at fixed prices on official supply ships from San Blas or the missions, and ports were officially closed to all other nations" (Pubols 2010:33).

In 1810, the periphery (Mexico) began their movement for independence from the core (Spain) that lasted into the early 1820s. Mexico's movement toward independence placed the California missions in the position of being an economic powerhouse. This transformed the relationships between California, the frontier, and Mexico (the central power). The deterioration of Mexico and California's interregional relationship affected, for example, the schedule of ships coming from San Blas with yearly supplies. Another interregional effect was increased dependency between establishments such as the presidio 
and the missions. The presidio soldiers needed products from the missions, which they paid for with credit, since they lacked their salary. The missionaries and the military had to depend on their own and make their own supplies to survive.

$(\mathrm{O}) n$ the isolated frontier, California did not feel the full force of the wars for independence. What they did feel was an economic shock, with most Pacific port in the hands of rebels, the central government in Mexico City could no longer control California's economy, which it had so carefully designed as a contained and regulated system within the larger economy of New Spain. Over the next ten years, without the yearly supply ships from Mexico, most Californians faced shortages and deprivation. Between 1810 and 1821, only one official supply ship left San Blas for California (Pubols 2010:41).

However "the missions estates, built on Indian labor, produced surpluses of hides and tallow" (Pubols 2010:43). As supplies were still needed, another option was to depend on illicit trading with other vessels: "private Spanish ships began to arrive in California water from Peru, other parts of New Spain, and even the Philippines" (Pubols 2010:43). California was producing a surplus high enough that by 1813 , Pubols notes that:

California tallow was in high demand in Peru, where it was used to make candles, but merchants also snapped up cattle hides, sea otters pelts, hemp, wool, coarse blankets, wine, dried fish, and other local items. To feed their sailors, the offices of seagoing vessels purchased California wheat, beef, beans, eggs, vegetables, and other foodstuffs (Pubols 2010:42).

Another important factor that changed the dynamics of the economy in California was the opening of the ports, as "at least twenty American ships, as well a number of British and Russian vessels" (Pubols 2010:44) began to arrive on the shores of California to trade.

With these continuing economic needs, the Spanish colonial system required even more land and labor from the tribes. The stress that the new model of subsistence created was detrimental both physically and mentally to the natives. Historic records demonstrate that life in the missions was extremely structured in order to increase a surplus. However the 
wealth which was accrued was imbalanced, making the missions and the private/secular parties wealthy and not the indigenous who performed the labor.

\section{Agency}

As stated previously, Native Americans of the San Francisco Bay Area were faced with the onslaught of a colonialist system. This system was inherently violent; it was reinforced by threats of violence, absolute control, no legal options, and few points of negotiations, compromise or means of altering the system to native peoples' benefit. The structural violence under which the natives had to live eroded well-being and dehumanized the population, something which reinforced, perpetuated, and justified the exercise of violence and absolute control. When opportunities arose in which the natives could alter their situation, whether through violent or nonviolent means, their actions were met with organized, systematic, and violent response.

Beginning in 1769 , we see the first documented resistance developing in Southern California, noted by Fray Palou, when an armed group stole supplies from Mission San Diego de Alcala. At Mission San Gabriel, Padre Cambon who was concerned about the atrocities of the soldiers. He awoke on "October 11, 1771, the day after the impaling of the local chief's head, 'to find plumes of smoke signals all along the entire horizon. We investigated and learned that this was a general pow-wow of all the surrounding Rancherias, convoked to make peace between those of the sierra and those from the coast, mortal enemies up to this time'" (Monroy 1993:39). Years later, "on the night of November 4, 1775, the Yumans...attacked and burned the mission and created the first martyr of the Franciscans' cause in Alta California" (Monroy 1993:40). Douglas Monroy (1993) states "the revolt of 
San Diego emphasized the increasingly apparent failure of the Indians to flock to their priestly shepherds" (1993:41).

The tribes never were able to unite and confront the colonists. However, in October 1785, there was another attempt to attack the San Gabriel mission by a woman named "Toypurina, said to have been a green-eyed sorceress led the Gabrieleños against the Spanish soldiers and priests" (Monroy 1993:40). This other attempt did not succeed and the participants were captured. Similar efforts at resisting and revolting also occurred in the north-central area of Alta California, where the agency of the Ohlone Indians can be seen. Scholars such as Lightfoot (2005) and Milliken (1995) have argued that the natives in California missions had the agency to get into the mission system and then resist the colonial models of production and the occupation of their lands.

The colonial system used brutal means, including "imprisonment, or other curtailment of liberty" (Cook 1976:122) to control their subordinates. Cook suggests that "the operation of the mission system, therefore, involved an immediate, powerful restriction of the social and intellectual expression of the Indian, comparable with those previously discussed, which affected liberty, space, diet, and sex relations" (Cook 1976: 146). The mission system as explained by Cook created an atmosphere of fear that restricted social space, which many California Natives opposed and resisted. Scott's (1985) research on peasant resistance correlates with the attitudes and agency of the California Natives in their reaction to this system, helping to identify subtle daily forms of resistance, as well as more open acts of resistance. 
If the stresses of mission life led Natives to flee, the result would be brutal reactions by the Spanish/Mexicans. The social agency and the rise of several survival strategies of resistance towards these brutal policies can be seen in the written accounts by Californios. For example, in the account of Alferez Amador's expedition to capture runaways that resisted by leaving the mission, we can see the California Natives express their agency by fighting back:

We entered their village, only to meet great resistance from the Sacalanes. Much as we tried to tell them that we did not wish to fight them, but that we merely wanted to take away the Christians, they would not listen to any of our assurances whatever, but began an attack on us, killing one horse, and wounding two others. Seeing that they were out for battle, were obliged to use our arms to make them surrender. Although we killed seven of them in the skirmish, yet, after more than two hours of fighting, they still would not give up. There were only about fifty Indian men and women engaging us, but these had their quivers full, and had many more bundles of them, in reserve by their sides. Moreover, they had dug trenches in the center of their village, as fortifications for attacks against us, without being harmed themselves. So, to offset this strategem (stratagem), we found it necessary to dismount and to fight them hand to hand with our swords and lances before forcing them to surrender (McCarthy 1958:65).

California indigenous men and women took up arms against the colonists who had superior weaponry and horses. However, the California natives likely fought back because they preferred that to returning to missions, which demanded hard labor and submission to the Spanish system of control.

Some tribes resisted the mission influence and provided protection for runaway neophytes. Earlier firsthand accounts from Fray Santa Maria expedition in 1775 to the Carquinez Strait perhaps provides evidence how villages that resisted were structured with powerful chiefs who had control of at least 400 warriors (Galvin 1971). However, Cook's (1976) study provides evidence that in 1805 , as expeditions were taking place, natives 
abandoned their villages for months at a time, welcomed the colonists, or resisted. Wilcox argues that "while armed resistance was a common feature of many of these interactions, the Pueblos (New Mexico) also attempted to defend themselves and maintain social distances through migration, regional abandonment, and mobility" (2005:97). This same reaction can be seen from the Ohlone natives after settlements and missions were established.

Secular/governmental and ecclesiastical institutions did not see eye to eye on issues on dealing with the indigenous people. These two power brokers had different goals for how the California Native societies should be integrated to society. The government/secular power argued that the church had acquired too much land and power over the Natives. The missionaries feared that the government was going to disempower them, which would mean that as the government pushed for a distribution of power to the Indians, the church's control would diminish. Nevertheless religious, governmental, and secular entities were all dependent on the native as they needed a labor force. A letter written in 1799 by Felipe de Neve, a governor of California, and Junipero Serra was translated by Beebee (2001). The letter discusses how the church was to implement alcaldes representatives of tribes: "Let Francisco... be the first alcalde...Another alcalde might be the chief from one of the Rancherias" (Beebe and Senkewicz 2001: 220). This evidence shows Neve's was concerned about how power would be distributed.

Amidst the ecclesiastical and governmental groups were the indigenous people, who were seen as simplistic, incapable of making decisions or being left alone in the Spanish/Mexican realm. However, scholars (Bean and Vane in Boxberger 1990; Dobyns 1966; Leventhal et al. 1994; Sandos 2004) that have taken the initiative to understand the 
Native Americans of the Bay Area have learned that they were a complex society with their own culture, socially and ideologically. The California Indians developed complex ranked chiefdoms, as evidenced by socially stratified inherited positions of authority that in their cultural world provided balance. Titles "such as 'wealthy person,' 'commoner,' 'poor person,' and the poor (sometimes slaves and vagabonds, as well) existed in most groups" (Bean and Vane 1990: 279). The Native Americans had a ranked society and sent their families into the mission, and some of them became alcaldes/regidores, representing tribal members and Indian auxiliaries. This continuity of indigenous leadership discloses social agency of the California natives in the colonial system.

\section{Indigenous Archaeology}

Employing Indigenous archaeology is important as it includes the indigenous perspective of history that is often absent in the realm of thought contemporary society, as well as in various social science-related disciplines. In reanalyzing history that has for the most part been written by European-Americans to justify their treatment or create an "invisible Indian," indigenous and non-indigenous scholars have contributed to writing a history with new methodologies that unmask the terminal narratives of conquest, instead showing a more holistic history.

In analyzing the documents of this study, it is apparent that the California Indians from 1769 to 1846 were indeed visible. The complex societies that they had developed prior to European contact were affected by the colonial system, and a reevaluation of historical documents allows us to see the stresses and reactions of these indigenous people. This 
allows us to acknowledge the depth of Native cultures before contact, as well as recognize their continued persistence through the colonial period and beyond.

As Watkins (Wilcox 2009), a Native American archaeologist notes, there is a need "for a development of a kind of archaeology that recognizes, integrates, and is responsive to the concerns of indigenous people throughout the world" (2009:21). Including an indigenous perspective of history provides a window to their past, bringing to light the early struggles endured by many of the indigenous peoples of the Americas.

\section{Persistence}

Persistence of the Ohlone Natives becomes evident when viewing how they developed adaptive survival strategies in order to survive into the 20th and 21st centuries. Panich (2013) suggests that in order to get away from the terminal narratives of Native Americans, three contemporary archaeologies of persistence are advocated that include identity, practice, and context. When it comes to the Ohlone tribal community's experience, we see persistence through their identity being passed on over time, despite the major stresses of the colonial system. Just as they had existed before contact, they continued to maintain identity throughout the mission period and beyond.

Mitchell and Scheiber note (Panich 2013:109) that indigenous peoples did not change simply due to having contact with colonizers. Instead, change "came from within native societies that drew on existing beliefs and practices to actively negotiate the colonial period" (Panich 2012:109). Through the practice perspective, we can examine the daily life of Bay Area Natives. Some continued to live in their villages and practice their traditions; however, it must be kept in mind that although contact did affect the natives in many ways, their 
traditions were also evolving themselves, regardless of European contact. Others entered the mission system, with many staying on and working while others broke away and sought refuge elsewhere. These neophytes were "simultaneously negotiating new cultural structures (and power relations) in the form of European colonialism" (Panich 2013:109). No matter where they spent time in their daily lives, the indigenous people were their own agents of change, something which looking at practice can help illustrate.

Looking at context, according to Panich, is a good way to "overcome terminal narratives" (2013:109). After all, as Silliman notes (Panich 2013:109), "Native cultures were not static prior to the arrival of European colonists, nor did the moment of contact freeze native societies." Contextualizing the experiences of Native Americans allows their history to be seen not as disjointed or only within the context of colonialism, but as a history stretching long before contact and continuing on after.

Placing Pomponio, Estanislao, and Yozcolo into to historical context demonstrates both adaptive strategies and persistence. Pomponio came into the mission when he was around four years old, but maintained his identity by never denying his native status, even though he had become Catholic. Estanislao maintained his connections with his fellow villagers in the San Joaquin Valley, who then had the agency to gather other leaders from missions San José, Santa Clara and San Juan Bautista when he broke away in revolt. Yozcolo, like the others, became an alcalde, thus adapting to the mission system. However, he maintained his native identity by abandoning the mission and raiding it for his tribe, even liberating some individuals from the mission quarters. 
These leaders that early historians portray as dangerous criminals should have a place in history as Native American heroes who fought for their people, just like the Sitting Bull or Red Cloud amongst the Lakota tribes. A unidirectional history written from the view of the colonists has made Native peoples invisible, but now we should consider alternative interpretations by applying the indigenous perspective to history.

\section{Summary}

The indigenous perspective to the colonization of Alta California is characterized by their coordinated and widespread resistance amidst biological and cultural persistence. Evidence from primary records shows that the native peoples of Alta California had social agency as they had lived in this area for thousands of years before the colonists arrived. The understanding of their history has been previously written with a unidirectional perspective which has created myths and misinformation about their lives, creating the Invisible Indian. On the other hand, by applying an indigenous perspective to those historical accounts that were originally written by the colonists, one can piece together a holistic and more balanced view of history. 


\section{CHAPTER 6: CONCLUSIONS}

Earlier in this study it was suggested that much of the previous work on Spanish early colonial California provided a narrative which largely ignored the indigenous response, resistance, and ensuing persistence, viewing the era through the lens of the dominant colonial society. While works from Bancroft (1886), Kroeber (1925), Holterman (1970), Brown (1975), Cook (1976), Field et al 1992, Leventhal et al. 1994, and Milliken (1995) have vastly improved our understanding of indigenous societies in the late 18th and 19th centuries, this project highlights several areas of investigation of their colonial experiences from 1769 to 1846 in which our understanding can be further improved. The foremost concern of this study is the importance of including an indigenous perspective, which can provide a better understanding of the impacts of the pre-contact, missionization and later Mexican periods in Alta California. Furthermore, scholars need to include the response and resistance of natives in Alta California narratives in their historic studies of the missions. Without this perspective, they would be omitting important considerations of history without acknowledging the persistence of indigenous people through present-day (the survivors).

Further, this project is poised to address several questions that many previous studies did not directly address:

1) In what ways may Native American resistance leaders be considered criminals versus unsung heroes for their efforts to liberate their people from mission life?

2) How does a reexamination of primary documents and historical records provide alternative perspectives about the Native American response and adaptive strategies 
in relation to the arrival and establishment of presidios, missions, and pueblos within their aboriginal homelands?

3) How does the history of Alta California mission rebellions relate more broadly to the course of Spanish/Mexican colonial history?

4) Employing theoretical methodologies used by Wilcox (2009) in his study of the pueblo region of the American Southwest, how can we link the history of resistance and continued persistence of those Native Americans aboriginal to the modern tribal entities in the greater San Francisco Bay Area?

Connecting the San Francisco Bay Area Native American response, resistance, and ensuing persistence to larger global and interregional processes captures a critical understanding of the native struggles following the Spanish colonists' arrival. By employing Spanish primary and secondary sources to investigate how colonial systems established superior and subordinate relationships between colonists and indigenous people the stated research questions can be addressed. This thesis has demonstrated how the study of ethnohistory can provide methods to understand Native Californian experiences that ultimately transformed their social and physical world. By employing a bottom-up approach to history, which is different from an ethnographic or a historical approach, this project contributes to a greater understanding of Native American and colonized cultures and resultant behaviors such as armed resistance.

In the first chapter the intellectual framework in which this study is situated was presented to the reader with the main sources and evidence used to address my research questions. I argued the San Francisco Natives did ultimately deploy various adaptive 
strategies including maintaining social distances through migration, regional abandonment, and mobility. I also suggested that this was one of the primary causes of depopulation of territory, which can stand as an alternative to the disease model forwarded by Cook (1976) and others. Finally, this project shows that employing primary and secondary sources can offer potential alternative perspectives of the history relative to the study of Bay Area indigenous groups, by placing them into historical context in order to understand their response and resistance to the imposed Spanish colonial mission system.

In the second chapter I presented the historical background of the Alta California indigenous people, the arrival of the colonists, and the impacts from the later the Mission and Mexican Periods. Prior to Contact the California Indians had developed complex social systems (Bean and Vane 1990). During the formative years 1776 to 1796, colonists began to settle the San Francisco Bay Area and the surrounding valleys, founding missions, presidios, and a pueblo, and transforming the land by developing and applying old world economies. During this time the colonists began to settle and build missions and presidios. As the colonists began settling in indigenous land, the natives began to see the destruction and disruption of their physical, social, and spiritual universe. Based upon documents researched for this study we ascertained how the colonists initially offered gifts, and the Natives at certain times welcomed them. However on other occasions, we get a glimpse of the organization of armed forces in this complex native society, such as from Father Santa Maria's 1775 recollection of the 400 warriors that were commanded by a chief (Galvin 1971). 
After the establishment of the missions, the colonial program soon began to attract additional Native people. Once the Natives were brought in and baptized they became part of the labor force, or were incorporated into an indigenous army as Indian auxiliaries. Some were selected by Spanish authorities to become alcaldes to manage the indigenous populations at the missions. A central problem confronting the Spanish authorities and the missionaries was the escape of neophytes from the missions to their villages; sometimes one or two and at other times large numbers of neophytes would flee. This caused tension and as a result military expeditions were sent to recapture them. These expeditions were sometimes welcomed by tribes. However, at other times villages which protected the runaway neophytes were abandoned out of fear of Spanish military reprisal. At still other times the colonial authorities encountered armed resistance by the natives. This period was marked by continuous indigenous resistance that continued on into the American Period beginning after 1846.

In the third chapter I applied theoretical methodology to understand and contextualize the stresses that were affecting the Indians of the San Francisco Bay Area during the early Spanish colonial and later Mexican Period. These analyses include the political economy and world systems approach. Stephen W. Silliman's theory of labor, which states that labor drastically changed native peoples' daily lives both within and outside of the mission, was also presented. Indigenous archaeology, in which Native scholars including Michael V. Wilcox (2009) and Rosemary Cambra et al. (1996) provide a new lens in which to view native societies, was discussed. Also, a discussion of archaeologies of persistence, a theory of Lee Panich (2012) that centers on identity, practice, and cultural persistence was 
presented. Finally perspectives on agency as noted by Kent G. Lightfoot (2005), who focuses on indigenous people's patterns of social agency, and James C. Scott (1985), who calls resistance a "weapon of the weak," were presented.

In the fourth chapter I examined three cases of the three aforementioned Native American resistance leaders: Pomponio, a Coast Miwok who joined Mission Dolores in 1803, became an alcalde at mission San Rafael, and later left the mission and actually began to raid missions and ranchos; Estanislao, a Lakisamme who led a revolt in 1829; and Yozcolo, an alcalde from Mission Santa Clara who also revolted against the colonial system in the late 1820s. All of these indigenous leaders demonstrated resistance to the transformation of their territory and developed different survival strategies in order to try to liberate their people and raid Spanish properties. In this chapter I also introduced the methods of research which include translating Spanish documents which can help us to better understand the indigenous perspective to colonization.

Including an indigenous perspective in mission history allows for a new understanding of the underlying justification for resistance of the California Natives to the mission system. The California natives had the agency to revolt against a colonial system of oppression. When reviewing and contextualizing the period in which the three indigenous leaders resisted, it is clear that there is a correlation between these militant acts of resistance. Sandos states that "interest in striking against a common religious and secular foe led to a series of violent eruptions in the 1820s that shook the missions from San Rafael in the north to San Buenaventura in the south" (2004:172). 
The actions of Pomponio, Estanislao, and Yozcolo were not isolated events; rather they were a sign that a significant resistance movement had developed. Pomponio's actions were just the starting point of a period of resistance, happening at the time that Mexico became independent of Spain. During the time of Pomponio's raids, the Spanish authorities responded with expeditions to native villages in order to pacify Indians. Pomponio may have been seen as such a threat that the Californios felt expeditions to various villages could suppress future insurgency. Pomponio was executed in 1824; however his death did not stop indigenous resistance. On the contrary, the Chumash revolt was taking place in another part of the state, and the peak of resistance was still to come.

Estanislao was a leader who attracted a "pan-Indian movement of gentiles and neophytes of some magnitude" (Sandos, 2004: 171). In 1829, hundreds of Indians from Missions San José, San Juan Bautista, Santa Clara, Santa Cruz, neophytes and non-neophytes alike, joined with Estanislao in taking up arms against those who were tracking Estanislao down. Three expeditions attempting to capture Estanislao and his followers took place, however they were not successful in apprehending him. This powerful leader was never captured.

Yozcolo was also actively resisting colonial forces. Records state that he began raiding the ranchos and missions in the early 1820s. He may have been involved with Estanislao's group as well. Yozcolo continued to raid missions and free neophytes well into the 1830 s. 
These events were likely interconnected. Undoubtedly there were Indians who were resentful of their systemic mistreatment at the hands of the priests. This could have been the motivation of many to resist against the colonial system. The context of these acts of resistance can also allow for calibrated speculation of the motives of resistance. With the Mexicanization of California in 1821 came an increase of land grants being issued to California elites; this may have sparked action as the Indians began to see what was once their land — and later mission land—being taken by a powerful new oligarchy.

In the fifth chapter a discussion of my analysis using a multi-theoretical approach in conjunction with anthropological/archaeological and historical frameworks, attaching an indigenous perspective to generate an alternative perspective of California history. In 1769, the first year of the colonists' occupation, we see that it was less violent than later periods. However a powerful presence of social agency is present between the colonists and California Natives. Three reactions during the proto-colonization from 1769 to 1776 come to surface: one that shows native flight, another in which the natives welcome the colonists as distinguished guests, and the third in which native groups showed armed resistance to colonizing forces.

This brings us to the research questions raised as a result of this study. In respect to Native American resistance leaders being considered criminals versus unsung heroes: in the eyes of the colonists, the Indians were savages, with the resistance leaders being an irritating threat to the colonists' way of life. However if we look at these leaders through an indigenous perspective, we see that they were courageous in standing up to the powerful 
colonial system. These leaders united their people, helped neophytes by freeing them from the bonds of mission life, and helped non-neophytes through raids to supply them with needs to live. This research shows, then, that rather than being considered criminals, these leaders can be seen as heroic in their attempts; after all, their resistance was for the benefit of their people.

Through the reexamination of primary and secondary documents, we are provided with alternative perspectives of Native American response to the colonial settlement of their aboriginal homelands. These historical documents contain subtle nuances that provide insight on important and even seemingly mundane occurrences of the time period. We see interactions between colonists and the Natives, stories of battles and resistance, descriptions of daily life within and outside of mission walls, and customs of both the Spanish and the Native Americans. Access to these details, some of which were previously unknown, gives us an idea of how and why Native Americans reacted the way they did.

The history of Alta California mission rebellions shows that the indigenous people were not totally disempowered and passive; rather, they showed agency through their resistance to the colonial system. As Sandos states, "Collective Indian action contributed to the decline of the California missions" (2004: 173). Native Americans continued to resist during the secularization period, and were often met with harsh punishment for doing so. As Naval officer Charles Wilkes noted (Shoup and Milliken 1999) after an 1841-1842 visit to Mission Santa Clara:

The property acquired by the missions is looked upon as belonging to the state; the claims of the Indians are entirely overlooked, and in the event of their taking the cattle that in truth belong to them, they are severely punished...Smarting under such wrongs, it is not surprising that the Indians should retaliate. 
It seems, then, that the missions were being dismantled and the wealth accrued on the backs of Indian labor was being redistributed, although not to the Indians, but to the Californio elites.

Employing the methodologies of Wilcox does allow us to link the history of resistance to the continued persistence of Native Americans of the San Francisco Bay Area. Studies such as this one are meant not to discredit history as we know it but instead enrich it. History that is only portrayed through the eyes of colonizers can be distorted, hence the idea of the invisible Indian and terminal narratives which imply that Native people along with their respective tribes are no longer in existence (Kroeber 1925). Such views of history disconnects modern Native Americans from their ancestral history. We see that the American Indians of the mission period did in fact have agency, attempting to take control of their lives by resisting rather sitting idly by or solely being the victims of disease as we are often taught. They did, in fact, survive into the present, and studies such as this one allow us to see their persistence.

Pomponio, Estanislao, and Yozcolo are individuals who are not widely known by the general public today, however this study seeks to revisit and highlight these unique Native American resistance leaders. These men rose to action when they witnessed the collapse of their respective cultures, villages, ecology and way of life. The intent of this study is to contribute to our collective understanding as social scientists about the role resistance leaders played during Spanish colonial times in California. Hopefully this study will spark continued research on these as well as other resistance leaders and indigenous resistance movements in California. Perhaps then modern California Indian people such as the Muwekma Ohlone 
Tribe of the San Francisco Bay Area can point to alternative interpretations about their ancestors who were missionized in the three Bay Area missions and honor the leaders who decided not to succumb to the odious yoke of colonialism.

It is my hope that this work may serve as a model for future research for both myself and others to understand a history that is all too often silent in our history books. Although our view has been imbalanced, the indigenous perspective can provide us with the tools to rectify our view of history, making it more encompassing. The failure of not conducting meaningful research in order to document connections between the past and present, as advocated by Indigenous archaeology, leads to contemporary issues and challenges by the tribes of today. This cannot be ignored, as acknowledging the indigenous past validates the struggles of Native Americans of the present and future. 


\section{REFERENCES CITED}

Asad, Talal

1974 Anthropology and the Colonial Encounter. Atlantic Highlands, NJ: Humanities Press International

Atalay, Sonya

2006 Indigenous Archaeology as Decolonizing Practice. The American Indian Quarterly 30(3-4):280-310.

Arriaga, Raymundo

1801 Letter to the commissioner of San José de Guadalupe. 11 August 1801. (5), 232. Ernest Pinoris trans. Mexican archives Pueblo of San José 1792-1859. California Room Archives:San José State University.

1802 Letter to commissioner of San José de Guadalupe. 20 February 1802. (IV), 591-595. Translations of Spanish and Mexican archives Pueblo of San José 1792-1859. California Room Archives, San José State University.

Beebe, Rose Marie., and Robert M. Senkewicz eds. 1996 The History of Alta California A Memoir of Mexican California Antonio Maria Osio. Madison, Wis.:The University of Wisconsin Press.

2001 Lands of Promise and Despair: Chronicle of Early California, 1535-1846.

Berkeley, Ca: Heyday Books.

2006 Testimonios Early California through the Eyes of Women 1815-1848.The Bancroft Library, Berkeley: University of California.

Bancroft H. Hubert

1886 History of California, Vol. 2, 1801-1824. San Francisco:The History Company Publishers.

1888 California Pastoral, Vol. 34, 1769-1848. San Francisco:The History Company Publishers. 
Blind, Eric Brandan, Barbara L, Voss, Sannie Kenton Osborn, and Leo R. Barker. 2004 El presidio de San Francisco : At the edge of empire. Historical Archaeology, 135149.

Bolton, Herbert Eugene.

1930 Anzas's California Expedetions 5 volumes Berkeley:University of California Press

Bean, Lowel J. and Sylvia Brakke Vane

1990 California Culture Area. In Native North Americans An Ethnohistorical Approach, Daniel Boxberger, L. ed. P p. 265-299. Dubuque, La.:Kendall/Hunt Publishing Company.

Brown, Alan K.

1975 Pomponio's World. The San Francisco Westerners, Argonaut (6)

Cambra, Rosemary, Alan Leventhal, Laura Jones, Julia Hammett, Les Field, Norma Sanchez and Robert Jurmain

1996 Archaeological Investigations at Kaphan Umux, the Three Wolves Site, CA-SCL-732: A Middle Period Prehistoric Cemetery on Coyote Creek in Southern San José, Santa Clara County, California. Report prepared for the Santa Clara county Traffic Authority and the California Department of Transportation, District 4 for the Highway 85 Riparian Mitigation Project at Silicon Valley Road and Highway 101.

Castro, Felipe

1996 Historia de los pueblos indigenas de Mexico. La rebelion de los indios y la paz de los Españoles. Centro de Investigaciones y Estudios Superiores en Anthropologia Social. Col. Alpes, 01010, D.F.

\section{Cook F. Sherburne}

1943a The Conflict Between The California Indian and White Civilization, I: The Indian Versus the Spanish Mission. Ibero-Americana 21. Berkeley, Calif.

1943c The Conflict Between The California Indian and White Civilization, IV: Trends in Marriage and Divorce since 1850. Ibero-Americana 21. Berkeley, Calif.

1976 The Conflict Between The California Indian And White Civilization. Berkeley and Los Angeles, CA: University of California Press. 


\section{Dobyns F. Henry}

1966 An Appraisal of Techniques with a New Hemispheric Estimate. Current Anthropology 7(4):395-416.

Engelhardt, Zephyrin

1924 San Francisco or Mission Dolores. Chicago:Franciscan Herald Press.

Erickson A. Paul, and Liam D. Murphy

2003 Readings for a history of anthropological theory. Canada:University of Toronto press.

Fages, Pedro

1937 A Historical, Political and Natural Description of California by Pedro Fages, Soldier of Spain (1775), Herbet I. Priestly, trans. Berkeley: University of California Press:

(Reprinted by Ballena Press, Ramano, California, 1972).

Farnsworth, Paul

1992 Indians, and Cultural Continuity. Historical Archaeology, The Archaeology of the Spanish Colonial and Mexican Republican Period, 26(1), 22-36.

Vallejo, Mariano Guadalupe, Glen J. Farris, and Rose-Marie Beebe.

2000 Report of a Visit to Fort Ross and Bodega Bay in April 1833. (4). California Mission Studies Association.

Field Les W., Alan Leventhal, and Rosemary Cambra

2013 "Mapping Erasure: The Power of Nominative Cartography in the Past and Present of the Muwekma Ohlone on the San Francisco Bay Area". Recognition, Sovereignty Struggles, and Indigenous Rights in the United States: A Sourcebook. Amy E. Den Ouden and Jean O'brien, eds. Pp. 287-309. Chapel Hill, NC: University of North Carolina Press. 


\section{Bojorges, Juan}

1877 Recuerdos Sobre la Historia de California. Gustavo A. Flores, trans., BANC MSS CD 46 The Bancroft Library, University of California Berkeley 14-22.

Galvin, John (Editor)

1971 The First Spanish Entry into San Francisco Bay 1775. San Francisco, CA: Howell Books.

Geiger, Maynard, and Clement W. Meighan.

1976 As the Padres Saw Them: California Indian Life and Customs as Reported by the Franciscan Missionaries, 1813-1815. Santa Barbara CA: Santa Barbara Mission Archive Library.

Gray, Thorne B.

1993 The Stanislaus Indian Wars the Last of the California Northern Yokuts. Modesto: The Mchenry Museum Press.

Holterman, Jack

1970 The Revolt of Yozcolo: Indian Warrior In the Fight for Freedom. American Indian Historical Society. The Indian Historian. (3), 1-23.

Hoskin, Beryl

1961 A History of the Santa Clara Mission Library. Biobooks. Oakland: California.

Hurtado, L. Albert

1988 Indian Survival on the California Frontier. New Haven: Yale University Press

Hurt, R. Douglas

2002 The Indian Frontier, 1763-1846. University of New Mexico press. 
Hylkema, G. Mark

2002 Tidal Marsh, Oak Woodlands, and Cultural Florescence in the Southern San Francisco Bay Region. In Catalysts to Complexity: Late Holocene Societies of the California Coast, eds. Jon M. Erlandson and Terry L. Jones, pp. 205-232. Perspectives in California Archaeology 6, series editor J.E. Arnold. Institute of Arhcaoelogy. Los Angeles: University of California.

Jackson, Robert H.

1994 Indian Population Decline: The Missions of Northwestern New Spain, 1687-1840. Alburquerque: University of New Mexico Press.

Jackson, H. Robert, and Edward Castillo 1995 Indians, Franciscans, and Spanish Colonization: The Impact of the Mission System on California Indians. Albuquerque: University of New Mexico Press.

Jones, Terry L. and Jennifer A. Ferneau

2002 Deintensification along the Central California Coast. In Catalysts to Complexity, Late Holocene Societies of the California Coast, edited by Jon M. Erlandson and Terry L. Jones Perspectives in California Archaeology (6), 205-232 Costen Institute of Archaeology, University of California, Los Angeles.

Kroeber, Alfred L.

1967 (1925) Handbook of the Indians of California. Berkeley, CA: California Book Company, Ltd.

Lightfoot, Kent G.

2005 Indians, Missionaries, and Merchants: The legacy of Colonial Encounters on the California Frontiers. Berkeley: University of California Press.

Lee, Panich M.

2012 Archaeologies of persistence: Reconsidering the Legacies of colonialism in Native North America. American Antiquity 78(1), 2013 105-122. 
Leventhal, Alan

1993 A reinterpretation of some Bay Area shellmound sites: a view from the mortuary complex from CA-Ala-329, The Ryan Mound. Master's thesis, San Jose State University.

Leventhal, Alan, Les Field, Henry Alvarez and Rosemary Cambra 1994 The Ohlone: Back From Extinction. In The Ohlone: Past and Present edited by Lowell John Bean. Ballena Press Anthropological Papers (42). Menlo Park, California.

Leventhal, Alan, Diane DiGiuseppe, Melynda Atwood, David Grant, Susan Morley, Rosemary Cambra, Dr. Les Field, Charlene Nijmeh, Monica V. Arellano, Susanne Rodriguez, Sheila Guzman-Schmidt, Gloria E. Gomez, and Norma Sanchez 2011 Final Report on the Burial and Archaeological Data Recovery Program Conducted on a Portion of the Mission Santa Clara Indian Neophyte Cemetery (1781-1818): Clareño Muwékma Ya Túnnešte Nómmo (Where the Clareño Indians are Buried) Site (CA-SCL30/H). Report Prepared for Pacific Gas and Electric Company.

Leon-Portilla, Miguel

1970 Fray Francisco Palou Relación histórica de la vida y apostólicas tareas del venerable padre Fray Junípero Serra y de las misiones que fundo en la California Septentrional, y nuevos establecimientos de Monterey (Francisco Palou's Life and Apostolic Labors of the Venerable Father Junípero Serra, Founder of the Franciscan Missions of California). Mexico: Editorial Porrua, S. A.

McCarthy F. Francis

1958 The History of Mission San José, California, 1797-1835. Fresno, CA: Academy Library Guild.

Milliken Randall

1995 A Time of Little Choice: The Disintegration of Tribal Culture in the San Francisco Bay Area 1769-1810. Menlo Park, CA: Ballena Press.

2008 Native American at Mission San José. A Malki-Ballena Press. Berkeley and Los Angeles: University of California Press. 
Mintz, W. Sidney

1986 Sweetness and Power: The Place of Sugar in Modern History. New York, NY:

Penguin Books.

Monroy, Douglas

1990 Among Strangers: The Making of Mexican Culture in Frontier California. Berkeley: University of California Press

Mora-Torres, Gregorio.

2005 Californio Voices the Oral Memoirs of José Maria Amador and Lorenzo Asisara.

Denton Texas: University of North Texas Press.

Nunis, B. Doyce Jr.

1998 Alta California's Trojan Horse Foreign Immigration. In Constested eden: California before the gold rush, ed. Ramon Gutierrez and Richard J. Orsi, 299-330. Berkeley:

University of California Press.

Palomares, J. Francisco

1887 Memorias de José Francisco Palomares. Gustavo A. Flores, trans. BANC MSS C-D

135 The Bancroft Library: The University of California Berkeley 26-31.

Perez, Erika

2011 "Saludos from your comadre" Compadrazgo as a Community Institution in Alta California, 1769-1860s. California History 88(4) 47-73.

Rawls, J. James

1986 Indians of California: The Changing Image. University of Oklahoma Press.

1992 The California Mission As Symbol and Myth. California History, LXXI(3), 342361.

Rosberry, William

1989 Antropologies and Histories: Essays in Culture, History, and Political Economy. New Brunswick, NJ: Rutgers University Press. 
Salomon, Carlos Manuel

2010 Pio Pico; The Last Governor of Mexican California. University of Oklahoma Press.

Sandos, A. James

2004 Converting California Indians and Franciscans in the Missions. New Haven \& London:Yale University Press.

Schneider, J., and R. Rapp

1995 Articulating Hidden Histories; Exploring the Influences of Eric R. Wolf. Berkeley: University of California Press.

Schuyler, L. Robert

1978 Indian-Euro-American Interaction:Archaeological Evidence from Non-Indian Sites.Robert F. Heizer ed. Pp. 69-79. Washington: Smithsonian Institution.

Scheper-Hughes Nancy and Phillipe Bougois 2004 Violence in War and Peace: An Anthology. Australia: Blackwell Publishing

Scott, James C.

1985 Weapons of the Weak everyday forms of peasant resistance. New Haven and London: Yale University Press.

Shoup H. Laurence and Randall Milliken

1999 Inigo of Rancho Posolmi: the life and times of a mission Indian. Menlo Park, CA: Ballena press

Silliman, Stephen W.

2001 Theoretical Perspectives on Labor and Colonialism: Reconsidering the California Missions, Journal of Anthropological Archaeology 20(4), 379-407.

Skowronek, K. Russell, Elizabeth Thompson, Veronica (Lococo) Johson, Anita CohenWilliams.

2006 Situating Mission Santa Clara de Asis: 1776-1851, Documentary and Material Evidence of Life on the Alta California Frontier: A timeline. Berkeley: Academy of American Franciscan History. 
Stanger, M. Frank, and Alan K. Brown

1969 Who Discovered the Golden Gate? The Explores' Own Accounts, How the discovered a hidden harbor and at last found its entrance. San Mateo, CA: San Mateo Historical Association.

Stickel E. Gary and Adrienne E. Cooper

1969 The Chumash Revolt of 1824: A Case for an archaeological Application of Feedback persis, Annual Report Archaeological Survey. Department of Anthropology, Los Angeles: University of California.

Stein, Gil J.

1999 Rethinking world-systems Diasporas, Colonies, and interaction in Uruk Mesopotamia. Tucson: University of Arizona Press.

Temple II Workman Thomas 1955 Memoirs of José Francisco Palomares. Translated from the manuscript in the Bancroft Library, Glen Dawson: Los Angeles

The Huntington Library 2006 Early California Population Project Database.

Wallerstein, Immanuel 1974 The Modern World-System: Capitalist Agriculture and the Origins of the European World-Economy in the Sixteenth Century. New York

Wilcox, Michael V.

2009 The Pueblo Revolt and the Mythology of Conquest. Berkeley: University of California Press.

Wolf, Eric R.

1959 Sons of the Shaking Earth. Chicago: The University of Chicago Press.

1982 Europe and the People Without History. Berkeley: University of California Press.

Vallejo, José de J. 1838 Letter to Constitutional Alcalde of San José. The Pueblo Papers: \# 494. History San José Archives, San José CA. 


\section{Appendix}

\section{Translation of Memorias de José Francisco Palomares}

\section{Paleographic Transcription}

Página 26

Muerte del célebre ladrón indio Yóscolo- Ponen su cabeza en un palo en la misión de Sta Clara pa. escarmiento de los de su clase.

Una noche (la fecha no recuerdo)/ el capitanejo Yóscolo con cinco/ de su partida, sorprendió el/ ranchito llamado "Encino Coposo",/ cerca de donde actualmte sé/ 5 encuentra la Mina de Guada/lupe, matando dos vecinos de/ él y llevándose robadas varias/ cosas. Algunos de los propietarios/ de bienes salieron inmediatamte./ 10 pa. la Mn. de Sta Clara con objeto/ de avisar al ministro (qe. lo era/ entonces el Pe.Mercado) lo/ qe. había acontecido y pedirle au/silio para perseguir a Yóscolo, pues/15 temían que este volviese con/ mas gente y los atacase pr. Se/gunda vez, causándoles mas/ daños- El Padre, tan luego/ como estuvo en su conocimiento todo/20 lo acontecido, se fué á ver al/

\section{Página 27}

Cabo de la escolta de la Misión,/ Manuel Peña, y le platico todo/ lo qe acontecía, conjurándolo á/ qe persiguiese á la partida/25 de Yóscolo qe. tantos perjuicios/ causaba a los habitantes de/ la comarca. El dicho cabo/ mandó entonces reunir á todos/ los indios de guerra de la Mi/30sion, hasta el número de cien/to, y les dijo que estuviesen lis/tos pa. el día siguiente, (esto/ sucedía la misma noche qe./_Yóscolo había dado el ataque,/35 como seis horas después); qe. iban/ a salir contra Yóscolo qe con cinco/ de su partida había sorprendido/ a los vecinos del Ranchito del/ Encino Coposo y matado á dos/40 de ellos. Los indios prometieron/ que así lo harían—al día siguien/te, muy demañana, el Cabo Peña/ salió 
de la Misión con sus/ cien indios y 4 o 5 soldados de/45 la escolta, y tanto cuanto lo/ permitía el número de gente y/

\section{Página 28}

el terreno se dirigió violento en/ persecución de los gentiles, -á/quienes alcanzó en la sierra,/50 algunas leguas mas allá de donde/ habían cometido los asesinatos./

Aunque Yóscolo llevaba tan corto/ número en comparación del de/ sus enemigos, no pr. so se en/55tregó prisionero, sino qe. trato/ de abrirse paso pr. entre ellos/ pero el Cabo Peña había dispues/to las cosas de manera qe. la/ fuga fuese imposible. Con/60 sus cien indios había formado/ un cerco alrededor de los 6/ ladrones, y sus soldados esta-/ban repartidos de trecho en/ trecho pa. animar á los com-/65batientes de piel negra. Asi es/ qe. los de Yóscolo pronto sucum-/bieron al golpe de tanta flechas/ como les disparaban de todos/ lados. Yoscolo murió peleando/70 como valiente, pues mientras/ tuvo fuerzas no dejó de causar/ daño á sus enemigos. Los in-/

\section{Página 29}

dios de Peña salieron algunos/ heridos y muerto el fiel Pedro/75 de quien se ha hablado anteriormte./ Los soldados no dispararon ni/ un solo tiro, pues ya se ha dicho/ de qe. se ocupaban. Cuando todo/ estuvo concluido Peña mandó/80 qe. se le cortase la cabeza a/ Yóscolo: un indio se encargó/ de hacer esta operación y chorreando/ sangre se la trajo al cabo, quien/ la fijó en el hierro de su lanza,/85 con sus propias manos, y así/ lo condujo á la Misión, donde/ mandó clavarla en un palo qe./ estaba en el frente de la Yglesia,/ permaneciendo allí 2 ó tres meses./ Los cuerpos quedaron insepultos/ en el lugar de la pelea, y solo/90 se trajeron á la Misión el del/ indio cristiano Pedro, pa. darle/ sepultura. Desde la 


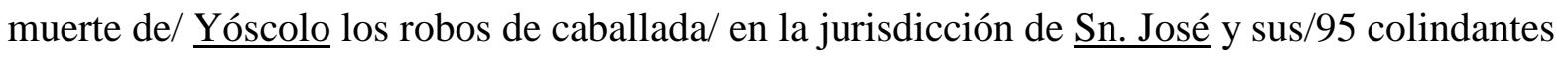
fueron menos fre-/cuentes. Este indio era el terror/

Página 30

de la Comarca. Algunos refieren/ el siguiente hecho, qe. yo creo ha/ sido inventado por alguna imagina/100ción novelesca. Dicen qe. Cuando/ estaban atacando á Yóscolo, un/ indio de los 100 qe. llevaba Peña,/ enemigo personal del ladrón, pidió/ permiso á aquel pa. pelear cuerpo/105 á cuerpo con su enemigo, y el/ Cabo se lo concedió mandando/ se suspendiese pr. un momento/ el combate. Entonces el indio/ desafío á Yóscolo en su lengua,/110 desafío qe. este admitió, salién-/dose á un sitio limpio qe. había/ pr. allí, á donde lo siguió el/ otro armado como el $1^{\circ}$ de arco/ y flechas. A la vista de ambas/115 partidas principió el combate/ singular, disparándose flechas/ cada vez á menos distancia,/ pr. qe. á medida que tiraban/ avanzaban un paso; pero nin-/120guno se hería, pr. qe. los dos/ eran igualmente agiles y experi-/mentados en esta clase de/ luchas. Por fin, después de/

\section{Página 31}

una hora de buscarse en vano/ 125los cuerpos, y cuando ya estaban/ apenas á una vara de distancia/ uno de otro, el indio de la Mi-/sión logró clavar una flecha/ en el corazón de su adversario/130 el bandido.- Siguió después/ la matanza de los otros y de-/más qe. se ha referido -1

Yóscolo era un indio de alta/ estatura, de color broncíneo, de/135 mirada cautelosa, muy feroz/ y valiente en las peleas perso-/nales. Siempre fue enemigo/ de los blancos y en su larga/ carrera de depredaciones nunca/ 140perdonó al qe(.) cayera en sus/ manos./ 142 


\section{Modern Spanish Translation}

Muerte del célebre ladrón indio Yóscolo- Ponen su cabeza en un palo en la misión de Santa Clara para escarmiento de los de su clase.

Una noche (la fecha no recuerdo) el capitanejo Yóscolo con cinco de su partida, sorprendió el ranchito llamado "Encino Coposo", cerca de donde actualmente se encuentra la Mina de Guadalupe, matando dos vecinos de él y llevándose robadas varias cosas. Algunos de los propietarios de bienes salieron inmediatamente para la Misión de Santa Clara con objeto de avisar al ministro (que lo era entonces el Padre Mercado) lo que había acontecido y pedirle auxilio para perseguir a Yóscolo, pues tenían que este volviese con más gente y los atacase por Segunda vez causándoles más daños El padre, tan luego como estuvo en su conocimiento todo lo acontecido, se fue a ver al Cabo de la escolta de la Misión, Manuel Peña, y le platico todo lo que acontecía, conjurándolo a que persiguiese a la partida de Yóscolo que tantos perjuicios causaba a los habitantes de la comarca.

El dicho cabo mandó entonces reunir á todos los indios de guerra de la misión, hasta el número de ciento, y les dijo que estuviesen listos para el día siguiente, (esto sucedía la misma noche que _Yóscolo había dado el ataque, como seis horas después); que iban a salir contra Yóscolo que con cinco de su partida había sorprendido a los vecinos del Ranchito del "Encino Coposo" y matado a dos de ellos. Los indios prometieron que así lo harían—al día siguiente, muy de mañana, el Cabo Peña salió de la Mision con sus cien indios y 4 o 5 soldados de la escolta, y tanto cuanto lo permitía el número de gente y el terreno se dirigió violento en persecución de los gentiles, -áquienes alcanzó en la sierra, algunas leguas más allá de donde habían cometido los asesinatos. Aunque llevaba tan corto número en comparación del de sus enemigos, no por eso se entregó prisionero, sino que trato de abrirse 
paso por entre ellos pero el Cabo Peña había dispuesto las cosas de manera que la fuga fuese imposible- Con sus cien indios había formado un cerco alrededor de los seis ladrones, y sus soldados estaban repartidos de trecho en trecho para animar á los combatientes de piel negra. Así es que los de Yóscolo pronto sucumbieron al golpe de tanta flechas como les disparaban de todos lados. Yóscolo murió peleando como valiente, pues mientras tuvo fuerzas no dejó de causar daño a sus enemigos.

Los indios de Peña salieron algunos heridos y muerto el fiel Pedro de quien se ha hablado anteriormente. Los soldados no dispararon ni un solo tiro, pues ya se ha dicho de que se ocupaban. Cuando todo estuvo concluido Peña mandó que se le cortase la cabeza a Yóscolo: un indio se encargó de hacer esta operación y chorreando sangre se la trajo al cabo, quien la fijó en el hierro de su lanza, con sus propias manos, y así lo condujo a la Misión, donde mandó clavarla en un palo que estaba en el frente de la iglesia, permaneciendo allí dos o tres meses. Los cuerpos quedaron insepultos en el lugar de la pelea, y solo se trajeron a la Misión el del indio cristiano Pedro, Para darle sepultura. Desde la muerte de Yóscolo los robos de caballada en la jurisdicción de San José y sus colindantes fueron menos frecuentes.

Este indio era el terror de la Comarca. Algunos refieren el siguiente hecho, que yo creo ha sido inventado por alguna imaginación novelesca. Dicen que cuando estaban atacando a Yóscolo, un indio de los 100 que llevaba Peña, enemigo personal del ladrón, pidió permiso a aquel para pelear cuerpo a cuerpo con su enemigo, y el Cabo se lo concedió mandando se suspendiese por un momento el combate. Entonces el indio desafío 
á Yóscolo en su lengua desafío que este admitió, saliéndose a un sitio limpio que había por allí, a donde lo siguió el otro armado como el $1^{\circ}$ de arco y flechas. A la vista de ambas partidas principió el combate singular, disparándose flechas cada vez a menos distancia, por que a medida que tiraban avanzaban un paso; pero ninguno sehería, por que los dos eran igualmente agiles y experimentados en esta clase de luchas.

Por fin, después de una hora de buscarse en vano los cuerpos, y cuando ya estaban apenas a una vara de distancia uno de otro, el indio de la Misión logró clavar una flecha en el corazón de su adversario el bandido.- Siguió después la matanza de los otros y demás que se ha referido.

Yóscolo era un indio de alta estatura, de color broncíneo, de mirada cautelosa, muy feroz y valiente en las peleas personales. Siempre fue enemigo de los blancos y en su larga carrera de depredaciones nunca perdonó al que cayera en sus manos. 


\section{English Translation}

Death of the famous Indian thief Yóscolo - they placed his head on a tree in the Mission of Santa Clara to warn people of his class.

One night (I don't remember date) the Indian captain Yóscolo with a group of five, surprised the ranch called "Encino (weary) Bushy oak", near where today is the Guadalupe mine, killing two neighbors from it and taking several stolen things. Some of the owners of the goods left immediately to Mission Santa Clara in order to advise the Minister (who was then the Father Mercado) what had happened and to ask for help to pursue Yóscolo, as they feared his returning with more people and attacking them for the second time causing them more damage the father, as soon as he was told everything that had happened, went to look for the Military cabo (commander) of the mission, Manuel Peña, and told to him everything that happened, conjuring to persecute the group of Yoscolo that caused so much harm to the inhabitants of the region.

The commander them ordered that gather all the war Indians from the mission be gathered, up to the number one hundred, and told them to be ready the following day, (this happened the same night that Yoscolo attacked, about six hours later); that they would go against Yoscolo with five of his group that had surprise the residents of the ranch "Encino Coposo" (Weary Bushy oak) and killed two of them. The Indians promised to be ready. The next day, early in the morning, commander Peña left the mission with its one hundred Indians and 4 or 5 soldiers of the escort, and in as much as the number of people and the land allowed it, he left violently in pursuit of the gentiles, whom they reached in the mountains, some leagues from where they had committed the murders. 
Although he (Yoscolo) had fewer in number in comparison with his enemies, he would not surrender. Instead he tried to make his way through them, but Peña had arranged things so that the escape was impossible - with his one hundred Indians (Peña) had formed a wall around the six thieves, and his soldiers were spread at intervals to encourage the dark skinned fighters. Thus, Yoscolo's people soon succumbed to the blows of so many arrows, as they were shooting at them from all sides. Yoscolo died fighting bravely, because while he had strength, he didn't let his enemies cause him harm.

Some of Peña's Indians were wounded and the faithful Pedro who I have spoken of earlier, died. The soldiers did not fire a single shot as I already had mentioned what their role was. When all was completed Peña ordered head of Yoscolo to be cut off: an Indian was charged to do this operation and brought it to the commander dripping blood, who fixed in the point of his lance, with his own hands, and led it to the mission, where he ordered it placed on a tree that was in front of the church, remaining there two or three months. The bodies were left unburied in the place of the fight, and they only brought to the mission the (body) of the Christian Indian Pedro, to bury him. Since the death of Yoscolo the theft of horses in the jurisdiction of San José and its surrounding were less frequent. This Indian was the terror of the region.

Some people refer the following fact, which I believe has been invented by some romantic imagination. They say that when they were attacking Yóscolo, an Indian of the 100 
that Peña brought, a personal enemy of the thief, asked permission to fight a duel with his enemy, and the captain granted him and commanded suspension of the combat for a moment. Then the Indian challenged Yóscolo in their language, a challenge he agreed to, he went out to a clearing was near there, to where the other (Indian) followed, armed like the first one with bow and arrows. The single combat began in view of both groups, shooting arrows every time at a shorter distance, because as the shot they advanced a step; but nobody was getting injured, because the two were equally agile and experienced in this kind of fight. Finally, after an hour of aiming in vain at their bodies, and when they were already just a vara (yard) apart, the Indian of the mission managed to drive an arrow into the heart of his adversary the bandit. What followed was the killing of the others and everything else aforementioned.

Yoscolo was an Indian of tall stature, bronze color, and a cautious gaze, very fierce and courageous in his personal quarrels. He was ever the enemy of the white people and in his long career of depredations never pardoned those who fell into his hands. 


\section{7 translation of Juan Bojorges Recuerdos Sobre la Historia de California}

\section{Paleographic Transcription}

Pagina 14

\section{Otra Campaña á Estanislao á las órdenes del Cabo de Cuera Pablo Pacheco}

"Salimos por el mes de Abril de 1827- del/ Presidio de San Franco en número de 40 Sol-/ Pagina 15

-dados mandados por el Cabo Pablo Pacheco,/ con dirección al Rio Estanislao, con motivo/ que el Capitán Estanislao había negado la/5 obediencia á los Padres de la Mision de S-/ José Fr. Narciso Durán y Fr. Buenaventura/ (no recuerda su apelativo) con motivo así-/ mismo que otro Capitán había seducido á/ mucha indiada de las Misiones de Sn-/10 José, Santa Clara y San Juan Bautista/ en número considerable; despues de 5 días/ de camino llegámos al espresado Rio, en/ donde encontrámos á la indiada, acam-/pada en un alto paredón del Río, en un/15 recodo muy grande en donde había un mon-/te de roble, sauce, encino y uva cimarrona./ Este campamento solo tenia dos entradas/ y muy estrechas, en donde los indios juntos,/ con mucha caballada, estaban encerra-20dos, teniendo del lado del Rio una fuente/ estacada de palos rajados, y tras de estos/ un vallado en que se cubrían, enterrados/ hasta los hombros, y desde donde ha/cían una fuerte defensa. Luego el Cabo/25 Pacheco mandó á un intérprete, que nos/ acompañaba desde la misión de San-/ José, á que le dijera que entregara á los/ Yndios Cristianos que tenía allía; á lo/

Pagina 16

que contesto Estanislao que no entregaba/30 á nadie; que si eran hombres que en/traran á sacarlos, diciendo muchas ma/las palabras é insultos en Castellano, descargando gran/ 
número de jarazos sobre la tropas; y esta/ de retirada, una descarga de balazos, por/35 que temían que les quitaran la salida/ para fuera del monte, yéndose á acam/par á poca distancia fuera del monte;/ un soldado que fué á asomarse para reco-/nocer el paredon, recibió un jarazo de lue-/40go que la pluma le hizo una herida/ en la cara. Ya reunidos los soldados,/ el Cabo Pacheco consultó con ellos sobre lo-/que podían hacer, diciéndoles que tenía/ vergüenza de regresar á Sn Franco á dar/45 parte de no haber hecho nada, en vis/ta del parage inaccesible en que estaban/ los indios y de los muy crecido que es-/taba el Rio para poder pasar al otro/ lado. Los soldados, viendo que en efecto-/50 nada se podía hacer, resolviéron todos unánimes regresar á su Presidio. El/ Capitán Arguello, impuesto de la situación/ de los indios enemigos, no tuvo que de-/cir absolutamente nada./55

El Cabo Pacheco sufría la broma de sus/ Pagina 17 compañeros los otros Cabos, y de algunos/ soldados con quienes se chanceaba, que/ le desían que en su primera campaña no/ había podido hacerles nada á los in-/60dios enemigos./ Cosa de dos meses despues de estos acontecimien-/tos, por orden del Capitan Dn Luis Anto/ Argüello salió para San José el Alfz Dn/ José Sanchez de Sn Franco á reunirse/65 con el Alferez Dn Mariano G. Vallejo, que/ venía mandado la Compa de Monterey;/ ambas fuerzas se compondrían de cosa de/ 200 Soldados, que unidos al Alcalde Al-/virez que iba en ausilío con algunos ve-/70cinos de San José e indiada formarían el número total de 250 hombres./ Salieron todos reunidos de la Mision de/ San José, provistos de armas y de un/ pequeño Cañon pedrero, que caminaba/75 cargado por una mula, así como las mun-/iciones y víveres: á los 4 días de camino/ se avistaron al campamto del Yndio Esta/nislao; pensando desde 
luego entrar al/ monte que ya he referido: desde luego/80 comenzaron a hacerles fuego con el cañon/ y las carabinas, y los indios á defender-/se con sus arcos y flechas,: desde luego/ Pagina 18

los indios jareáron á cuatro vecinos de/ los ausiliares quendando uno mortalmente/85 herido,(Tomas Espinosa?), que despues murió en su casa en/ el pueblo de S. José; de los indios no se/ supo si algunos fueron muertos ó heridos,/ por que ninguno penetro á su campo. Los/ soldados de Monterey decian á los de San/90 Franco; que iban á sacar á la indiada/ y su Capitan á nalgadas; pero ni unos/ ni otros al fin hicieron nada al enemigo,/ regresándose prontamte á los puntos de-/ donde habían salido./95

Es de advertir que el que redacta estos/ recuerdos nos salió en esta Campaña, por/ estar todavía Convaleciendo de la herida de/ jara que tenía en la cara, muy cerca/ del ojo izquierdo; pero todo esto que dicta/100 es por información de su compañeros/ que en diferentes ocasiones conversaban;/ así como por conversaciones de los vecinos/ que fueron en ausilio del Pueblo de San/ José á las órdenes del Alcade Dn Juan/105 Alvires./ Ya antes de esta Campaña había sa/lido sola la compa de Sn Franco man-/dada por Alférez D José Sanchez, con/ Pagina 19 el número de 40 soldados, y 40 Yndios/110 ausiliares de la Misión de San José, esta/ campaña fué más desgraciada que las/ anteriores, por que el Alférez perdió tres/ hombres de tropa, tomando á uno de ellos/ vivo los indios, conservándolo has-/115ta que se retiro la tropa; entonces Estanis-/lao mando llamar indios de otras Ran-/cherías, para que presenciaran el modo/ como lo iban á matar; lo colgáron de un/ pie al brazo de un roble, y 
comenzáron/120 todos á jarearlo; este soldado desgraciado/ se llamaba Andrés Meza, así que estuvo/ muerto lo descolgáron y lo quemáron. Otro/ de los Soldados fué muerto por sus mis/mos compañeros de un balazo, que esta/125 ban haciendo fuego á los indios por el/ lado opuesto: este soldado se llamaba Ygo/ Pacheco./

El otro soldado llamado Antonio Soto vino/ a morir á S. José de resultas de un ja/-130razo que recibió en el ojo izquierdo que ca/si le paso el cerebro./

En esta campaña saliéron heridos siete sol-/dados más, entre ellos el mismo que ha/ce estos recuerdos; en tal estado se retira-/135ron todos tristemente, caminando muy/

Pagina 20

despacio, por razon que tenían del venir cui-/dando á los heridos./

Se me pasaba hacer mencion que cuando/ ya salimos del monte donde batimos á los/140 Yndios de Estanislao, el Alférez Sánchez/ echó de ver que le faltaban cuatro sol-/dados; entonces ordenó que volviéramos/ al monte á ver si los libraban, encon-/trando á dos por el camino, muy heri-/145dos, que venían levantándose el uno al/ otro, y diciéndose, "no me dejes; compañero"/ y amenazando á los indios con sus cara-/binas sin estar cargadas, por que no/ lo podían hacer, pues que los indios los150 perseguían muy de cerca , y ellos favorecidos/ por sus adargas y cueras, que á no ha-/ber sido esto, habrían sido muertos: al/ encontrar la tropa dentro del monte á estos/ dos hombres cargáron sobre los Yndios/155 que retrocediéron, y aprovechando esta re-/tirada, los pusieron dos de sus amigos/ á la grupa de sus caballos, sacándolos/ de este modo del peligro: uno de estos/ soldados se llamaba Manuel Peña, y el/160 otro Lorenzo Pacheco./

El Alférez Sánchez insistía en sacar á los/ 2 que aún quedaban, que el uno se llamaba/ 


\section{Pagina 21}

Manuel Peña y el otro Ygnacio Pacheco; pero/ los soldados no obedecieron diciéndole al Alfé-/165rez que si volvían a entrar al monte, perde-/ría mas hombres; entonces mando tocar/ con el tambor retirada, y ya enteramente/ fuera del monte, salió con bastante indiada Estanislao, y tiró á los soldados un/170 tiro con una carabina de la de los mis-/mos compañeros, tirando su sombrero/ para arriba, y gritándoles en Español/ multitud de insultos muy groseros, y/ mentando el nombre de algunos de/175 los soldados./

El Alférez Sánchez hizo su retirada muy/ avergonzado y caminando á paso regular;/ cuando llegámos al presido no supimos/ que cuentas dió al Capitán Arguello/180 A nuestra llegada á San José/ ya se tenía noticias de nuestra derrota,/ y al avistarnos, dobláron con las cam-/panas, y se hicieron muchas demos-/traciones de gran duelo, retirándose la/185 tropa para S. Franco./

Descripcion de Estanislao. /

Era un hombre como de seis piés de al-/tura, de piel más bien blanca que abron-/zada, de cuerpo esbelto, y muy de á ca-/

\section{Pagina 22}

190ballo, la cara la tenía muy cerrada de bar-/ba; de edad de 53 a 40 años, natural y/ criado en la Misión de S José, empleado/ de vaquero ó amansador de mulas, siendo/ indio de buen carácter se echo a perder/195 con la amistad de otros indios de su/ ranchería en las visitas que les hacía/ quedando sublevado en una de tantas./

Santa Clara Junio 4 de 1877./

Juan Bogorges./200 
Por no saber firmar pone $\mathrm{x} /$ 


\section{Modern Spanish Translation}

\section{Otra Campaña a Estanislao a las órdenes del Cabo de Cuera Pablo Pacheco}

Salimos por el mes de Abril de 1827- del Presidio de San Francisco en número de 40

soldados mandados por el Cabo Pablo Pacheco, con dirección al Rio Estanislao, con motivo que el Capitán Estanislao había negado la obediencia a los Padres de la Misión de San José Fr. Narciso Durán y Fr. Buenaventura (no recuerdo su apelativo) Con motivo así mismo que otro Capitán había seducido a mucha indiada de las Misiones de San José, Santa Clara y San Juan Bautista en número considerable; después de 5 días de camino llegamos al expresado Rio, en donde encontramos a la indiada, acampada en un alto paredón del río, en un recodo muy grande en donde había un monte de roble, sauce, encino y uva cimarrona. Este campamento solo tenía dos entradas y muy estrechas, en donde los indios juntos, con mucha caballada, estaban encerrados, teniendo del lado del río una fuente estacada de palos rajados, y tras de estos un vallado en que se cubrían, enterrados hasta los hombros, y desde donde hacían una fuerte defensa.

Luego el Cabo Pacheco mandó a un intérprete, que nos acompañaba desde la misión de San José, a que le dijera que entregara a los indios Cristianos que tenía allí; a lo que contesto Estanislao que no entregaba a nadie; que si eran hombres que entraran a sacarlos, diciendo muchas malas palabras e insultos en castellano, descargando gran número de jarazos sobre la tropas; y esta de retirada, una descarga de balazos, porque temían que les quitaran la salida para fuera del monte, yéndose a acampar a poca distancia fuera del monte; un soldado que fue a asomarse para reconocer el paredón recibió un jarazo de lejos que la pluma le hizo una herida en la cara. Ya reunidos los soldados, el Cabo Pacheco consultó con ellos sobre lo que 
podían hacer, diciéndoles que tenía vergüenza de regresar a San Francisco a dar parte de no haber hecho nada, en vista del paraje inaccesible en que estaban los indios y de los muy crecido que estaba el rio para poder pasar al otro lado. Los soldados, viendo que en efecto nada se podía hacer, resolvieron todos unánimes regresar a su Presidio. El Capitán Arguello, impuesto de la situación de los indios enemigos, no tuvo que decir absolutamente nada. El Cabo Pacheco sufría la broma de sus compañeros los otros Cabos, y de algunos soldados con quienes se chanceaba, que le decían que en su primera campaña no había podido hacerles nada a los indios enemigos.

Cosa de dos meses después de estos acontecimientos, por orden del Capitán Don Luis Antonio Arguello salió para San José el Alférez Don José Sanchez de San Francisco a reunirse con el Alférez Don Mariano G. Vallejo, que venía mandado la Compania de Monterey; ambas fuerzas se compondrían de cosa de 200 soldados, que unidos al Alcalde Alvirez que iba en auxilio con algunos vecinos de San José e indiada formarían el número total de 250 hombres. Salieron todos reunidos de la Misión de San José, provistos de armas y de un pequeño cañón pedrero, que caminaba cargado por una mula, así como las municiones y víveres: a los 4 días de camino se avistaron al campamento del indio Estanislao; pensando desde luego entrar al monte que ya he referido: desde luego comenzaron a hacerles fuego con el cañón y las carabinas, y los indios a defenderse con sus arcos y flechas, desde luego los indios jarearon a cuatro vecinos de los auxiliares quedando uno mortalmente herido, Tomas Espinosa, que después murió en su casa en el pueblo de San José; de los indios no se supo si algunos fueron muertos o heridos, porque ninguno penetró a su campo. Los soldados de Monterey decían a los de San Francisco que iban a sacar a la 
indiada y su Capitán a nalgadas; pero ni unos ni otros al fin hicieron nada al enemigo, regresándose prontamente a los puntos de donde había salido.

Es de advertir que el que redacta estos recuerdos no salió en esta campaña, por estar todavía convaleciendo de la herida de jara que tenía en la cara, muy cerca del ojo izquierdo; pero todo esto que dicta es por información de su compañeros que en diferentes ocasiones conversaban; así como por conversaciones de los vecinos que fueron en auxilio del Pueblo de San José a las órdenes del Alcalde Don Juan Alvires.

Ya antes de esta campaña había salido sola la compania de San Francisco mandada por Alférez Don José Sanchez, con el número de 40 soldados, y 40 indios auxiliares de la Misión de San José. Esta campaña fue más desgraciada que las anteriores, porque el Alférez perdió tres hombres de tropa, tomando a uno de ellos vivo los indios, conservándolo hasta que se retiró la tropa; entonces Estanislao mandó llamar indios de otras Rancherías, para que presenciaran el modo como lo iban a matar; lo colgaron de un pie al brazo de un roble, y comenzaron todos a jarearlo; este soldado desgraciado se llamaba Andrés Meza, así que estuvo muerto lo descolgaron y lo quemaron. Otro de los soldados fue muerto por sus mismos compañeros de un balazo, que estaban haciendo fuego a los indios por el lado opuesto: este soldado se llamaba Ignacio Pacheco.

El otro soldado llamado Antonio Soto vino a morir a San José de resultas de un jarazo que recibió en el ojo izquierdo que casi le pasó el cerebro.

En esta campaña salieron heridos siete soldados más, entre ellos el mismo que hace estos recuerdos; en tal estado se retiraron todos tristemente, caminando muy despacio, por razón que tenían del venir cuidando a los heridos. 
Se me pasaba hacer mención que cuando ya salimos del monte donde batimos a los indios de Estanislao, el Alférez Sánchez echó de ver que le faltaban cuatro soldados; entonces ordenó que volviéramos al monte a ver si los libraban, encontrando a dos por el camino, muy heridos, que venían levantándose el uno al otro, y diciéndose, "no me dejes; compañero" y amenazando a los indios con sus carabinas sin estar cargadas, porque no lo podían hacer, pues que los indios los perseguían muy de cerca, y ellos favorecidos por sus adargas y cueras, que a no haber sido esto, habrían sido muertos: al encontrar la tropa dentro del monte a estos dos hombres cargaron sobre los indios que retrocedieron, y aprovechando esta retirada, los pusieron dos de sus amigos a los grupa de sus caballos, sacándolos de este modo del peligro: uno de estos soldados se llamaba Manuel Peña, y el otro Lorenzo Pacheco. El Alférez Sánchez insistía en sacar a los 2 que aun quedaban, que el uno se llamaba Manuel Peña y el otro Ignacio Pacheco; pero los soldados no obedecieron diciéndole al Alférez que si volvían a entrar al monte, perdería más hombres; entonces mandó tocar con el tambor retirada, y ya enteramente fuera del monte, salió con bastante indiada Estanislao, y tiro a los soldados un tiro con una carabina de la de los mismos compañeros, tirando su sombrero para arriba, y gritándoles en Español multitud de insultos muy groseros, y mentando el nombre de algunos de los soldados.

El Alférez Sánchez hizo su retirada muy avergonzado y caminando a paso regular; cuando llegamos al presido no supimos que cuentas dio al Capitán Arguello. A nuestra llegada a San José ya se tenía noticias de nuestra derrota, y al avistarnos, doblaron con las campanas, y se hicieron muchas demostraciones de gran duelo, retirándose la tropa para San Francisco. 
Descripción de Estanislao.

Era un hombre como de seis pies de altura, de piel más bien blanca que abronzada, de cuerpo esbelto, y muy de a caballo, la cara la tenía muy cerrada de barba; de edad de 53 a 40 años, natural y criado en la Misión de San José, empleado de vaquero ó amansador de mulas, siendo indio de buen carácter se echó a perder con la amistad de otros indios de su ranchería en las visitas que les hacía quedando sublevado en una de tantas.

Santa Clara Junio 4 de 1877.

Juan Bojorges.

Por no saber firmar pone $\mathrm{x}$ 


\section{English Translation}

Another campaign against Estanislao by orders of the leatherjacket soldier Pablo Pacheco

We left around the month of April 1827 from the Presidio of San Francisco with a number of 40 soldiers sent by the Commander Pablo Pacheco, in the direction the Stanislaus River, with the motive that the chieftain Estanislao had refused obedience to the Fathers of the Mission of San José Fr. Narciso Durán and Fr. Buenaventura (I don't remember his last name), with the reason that likewise another chieftain had seduced many Indians of San José, Santa Clara, and San Juan Bautista in a considerable number. After 5 days traveling we reached the aforementioned river, where we found the Indians, camping in a high wall of the river, in a very big bend where there was a forest of oak, willow, and wild grape. This camp only had two very narrow entrances where the Indians together with many horses were enclosed, having along the side of the river a fence of chopped logs, and after this a trench that gave them cover and reached their shoulders, and from which they made a strong defense. Then the soldier Pacheco sent an interpreter that had accompanied us from Mission San José to tell him to hand over the Christians Indians he had there. Estanislao answered that he would not hand over anybody and that if they were men enough to come take them out themselves, saying many bad words and insults in Spanish, and shooting a large amount of arrows at the troops. And the troops withdrew firing bullets because they feared that (Estanislao) might cut off their exit from the woods. As they went to camp a short distance outside the forest, a soldier who went to reconnoiter the Indian encampment, received an arrow shot from afar in which the feather wounded his face. 
Once the soldiers regrouped, Commander Pacheco consulted with them about what they could do, saying that it was shameful for him to return to San Francisco to report having done nothing, because of the inaccessible site where the Indians were and of how high the river was, making hard to cross. The soldiers, seeing that in fact that nothing could be done, decided unanimously to return to their Presidio. Ensign Argüello, informed of the situation of the Indian enemies, had absolutely nothing to say.

Commander Pacheco suffered the jokes of his companions and other commanders, and some other soldiers with whom he joked, who told him that on his first campaign he could do nothing to the Indian foes.

Two months after these events, by order of Ensign Don Luis Antonio Argüello the Ensign Don José Sanchez of San Francisco left for San José to meet with Ensign Don Mariano G. Vallejo, who commanded the company of Monterey; both forces would comprise a group of 200 soldiers, which together with the magistrate Alvirez who came to aid with some residents of San José and Indians would be a total number of 250 men. They left all together from Mission San José, equipped with weapons and a small cannon, or pedrero, carried by a mule, as well as ammunition and supplies. After 4 days of travel, (the company) sighted the camp of the Indian Estanislao, thinking to quickly enter the forest which I have already referred: they soon began to fire upon them with the cannon and the carbines, and the Indians began defend themselves with bows and arrows. Soon the Indians shot four of the settler auxiliaries, mortally wounding one, Tomas Espinosa, who later died at his home in the Pueblo of San José. Of the Indians we did not knew if some were killed or injured, because we were not able to penetrate their territory. The soldiers of Monterey told the ones of San 
Francisco that they would take out the Indians and its captain and give them a good spanking; but in the end neither one of them did anything to the enemy, who returned promptly to points where they came from.

It is to note that he who recounts these memories did not go on this campaign, because he was still injured from the arrow, which hit him on the face, close to the left eye. All this that he dictates is from information of his comrades who on several occasions spoke with him, as well as from conversations with settlers who came to the aid of the town of San José at the orders of the Magistrate Don Juan Alvires.

Already prior to this campaign the company from San Francisco had gone out on its own, commanded by Ensign Don José Sánchez, with the number of 40 soldiers and 40 Indian auxiliaries of the Mission San José. This campaign was more miserable than the previous ones, and the ensign lost three men of the troop, one of them taken alive by the Indians, who kept him until the troop withdrew. Then Estanislao commanded Indians from other villages be summoned, so as to witness the way they would kill him. They hung him by his foot to a branch of an oak tree, and all began to shoot arrows at him. (this unfortunate soldier was named Andres Meza), so when he was dead they lowered his body and burned it. Another of the soldiers was killed by his comrades, who were shooting at the Indians on the opposite side; this soldier's named was Ignacio Pacheco.

The other soldier named Antonio Soto came to die in San José as a result of an arrow wound to his left eye that almost penetrated his brain. 
This campaign left seven more soldiers wounded, among them the very one telling his memories. In such a state all sadly withdrew, walking very slowly because they had to care for the wounded.

I forgot to mention that when we already left the forest where we battled the Indians of Estanislao, Ensign Sánchez happened to see that four soldiers were missing; he then ordered that we go back to the woods to see if they could be liberated. Two were found along the road, very wounded, helping one another, and saying, "do not leave me, comrade," and threatening the Indians with their rifles without being loaded, because they could not do so, as the Indians were pursuing them very closely, and they were helped by their shields and leather jackets, for if it had not been for them, they would have been dead. Upon finding the troop within the woods, these two men fired towards the retreating Indians, and taking advantage of this withdrawal, two of their friends put them on the back of their horses, taking them out of the danger: one of these soldiers was named Manuel Peña, and the other Lorenzo Pacheco.

Ensign Sánchez insisted on retrieving the 2 remaining, one named Manuel Peña and the other Ignacio Pacheco; but the soldiers did not obey, saying to the Ensign that if they returned to the woods they would lose more men. Then he ordered they beat the drum of retreat. And once already entirely out of the woods, Estanislao came out with many Indians and shot at the soldiers with a rifle of one of their comrades, tossing his hat up in the air, shouting in Spanish very rude insults, and yelling the name of some of the soldiers.

Ensign Sánchez made his withdrawal with great shame and walking at a regular pace; when we arrived to the Presidio we didn't know what account he gave to Captain Arguello. 
Upon our arrival in San José, the news of our defeat was already known, and when they saw us, they rang the bells, and made many great mourning demonstrations, and the troop retreated to San Francisco.

Description of Estanislao.

He (Estanislao) was a man about six feet tall, of light rather than dark complexion, slender body, and was a fine horseman. He kept his beard very short; age of 53 or 40, born and raised in the Mission of San José, employed as a cowboy or a mule tamer. Being goodnatured Indian, he was ruined through the friendship of other Indians of his rancheria when he would visit them, and becoming a rebel during one of his visits.

Santa Clara 4 June 1877.

Juan Bojorges.

Not knowing how to sign puts an $\mathrm{x}$ 